



\section{THE WORK OF \\ EMIL FUCHS}

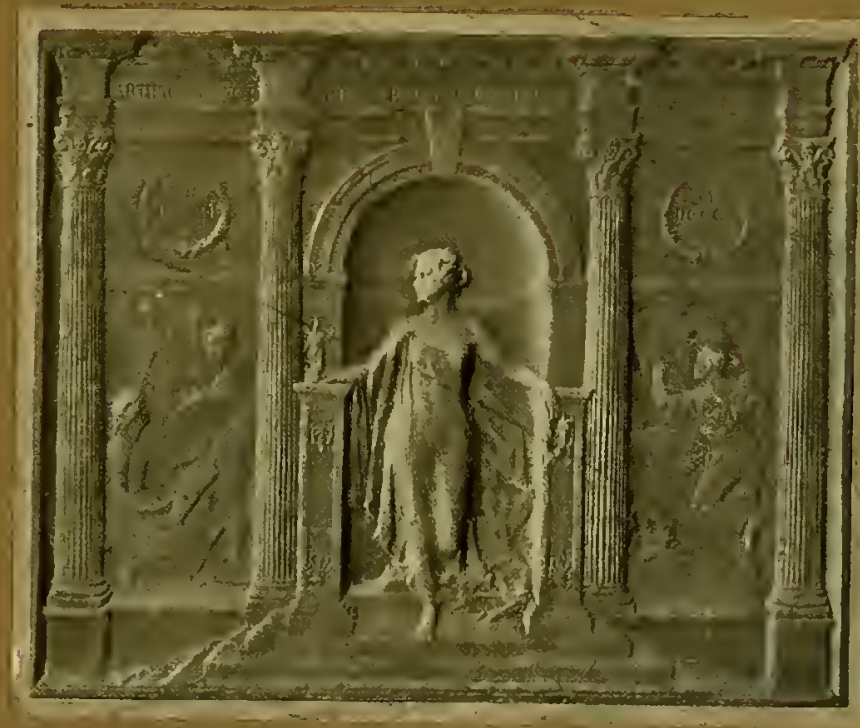

\section{B. तi 4}

AKGIOSY GIFT 1353 
<smiles>C1CCCCCC1</smiles> 

ic.

\section{,}






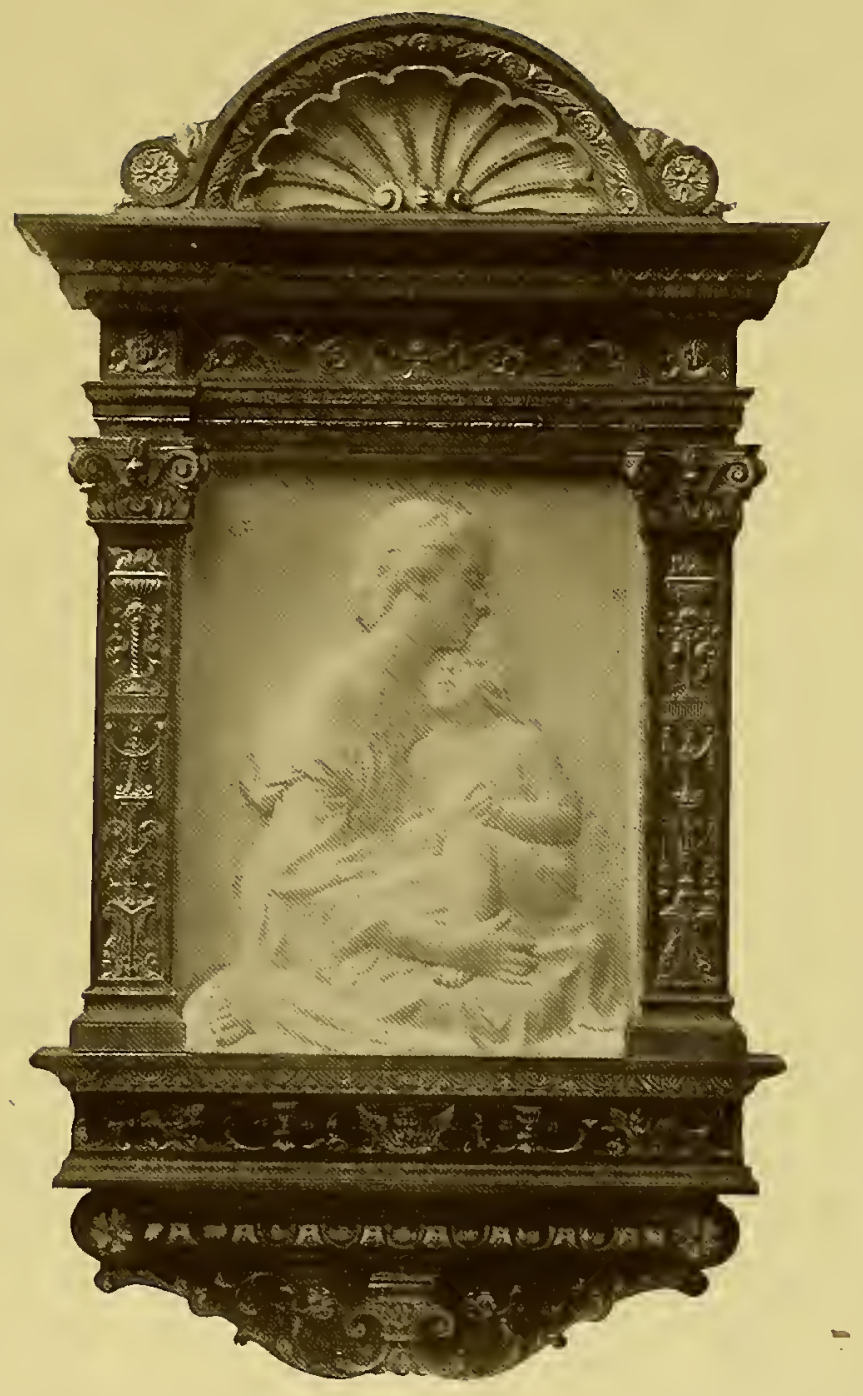




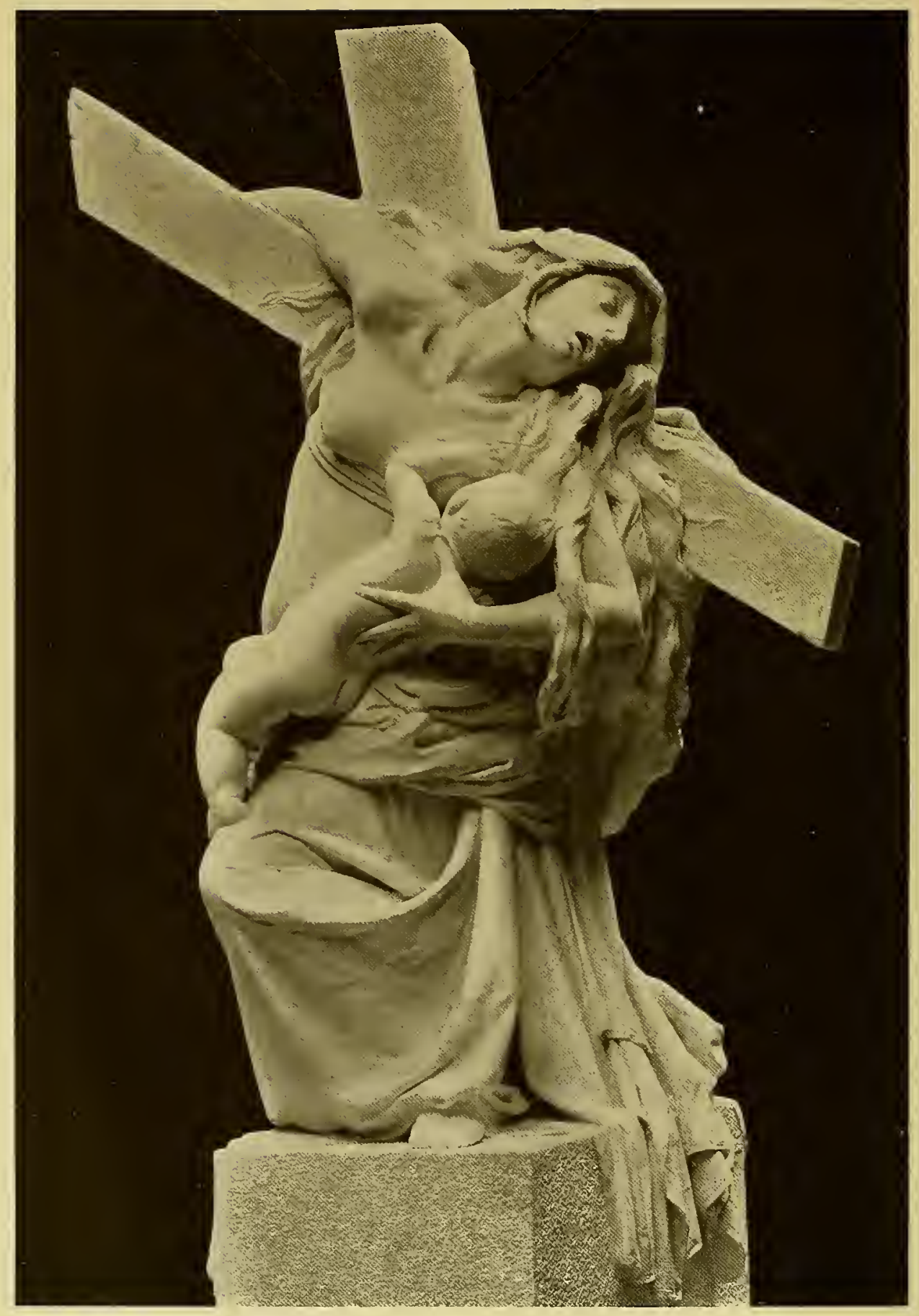

Mother's Love 


\title{
THE WORK OF EMIL FUCHS
}

\author{
ILLUSTRATING SOME OF HIS \\ REPRESEVTATIVE \\ PAINTINGS SCULPTURE MEDALS \\ AND STUDIES
}

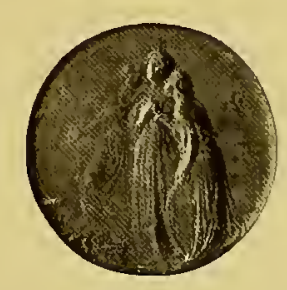

\author{
Issued on the Occasion of an Exbibition \\ of bis works under the Auspices of \\ Messrs Cartier \\ February 7 th to ellarcb 5 th 1921 \\ NEW York City
}





\section{PREFACE}

$W^{\text {HEN I went to Italy, now almost thirty years ago, encour- }}$ aged by a traveling-scholarship, I carried with me all the buoyancy and self-confidence, which is the privilege of youth-

"with thousand masts saileth fortb the boy."

A government studio, a life free from care, amid surroundings, every inch of which breathed Art and Poetry-no wonder, all of us, while toiling along the path of life, would look back upon these years with indescribable delight.

These are the years when we dare anything, and I was no exception to the rule, trying my hand at different branches of Art and in different mediums.

These are the years responsible for our most ambitious attempts, prompted only by lofty ideals.

But the day comes, and it comes soon, when we recognize the wide gap between ambition, which would carry us beyond our dreams, and realization, the fruit of sincere efforts. Our attitude toward Àrt and Life becomes more humble and if today I venture to show my work, 1 show it in that spirit.

Many of us share these feelings; few are able to give them more appropriate expression than in the following lines, which are so beautiful and true, that I may call them the guiding thought of my life:

"then it is better to die, struggling for the Supreme, than perish in the dust among the Commonplace." 


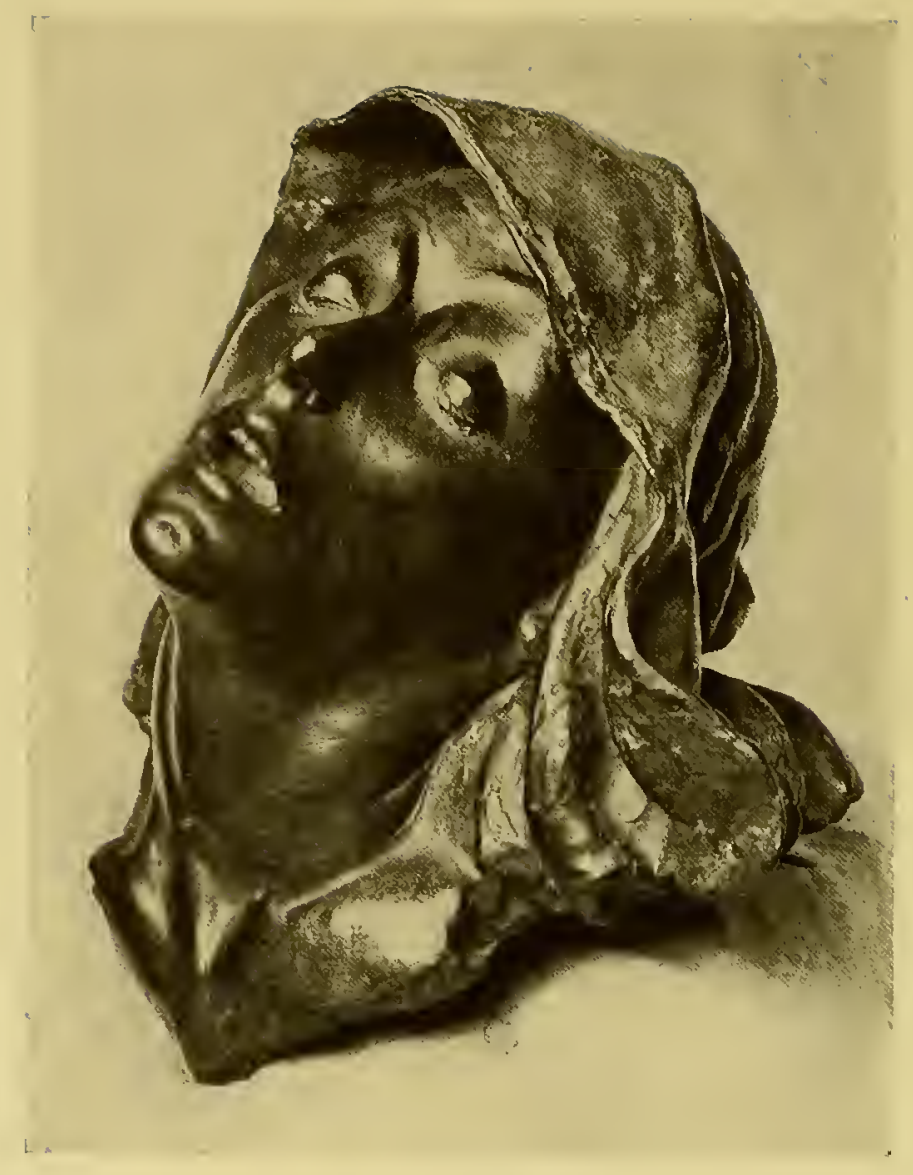

The Grip of Death BRONZE

DETAIL OF THE GROUP " MOTHER'S LOVE'

Frontispiece 

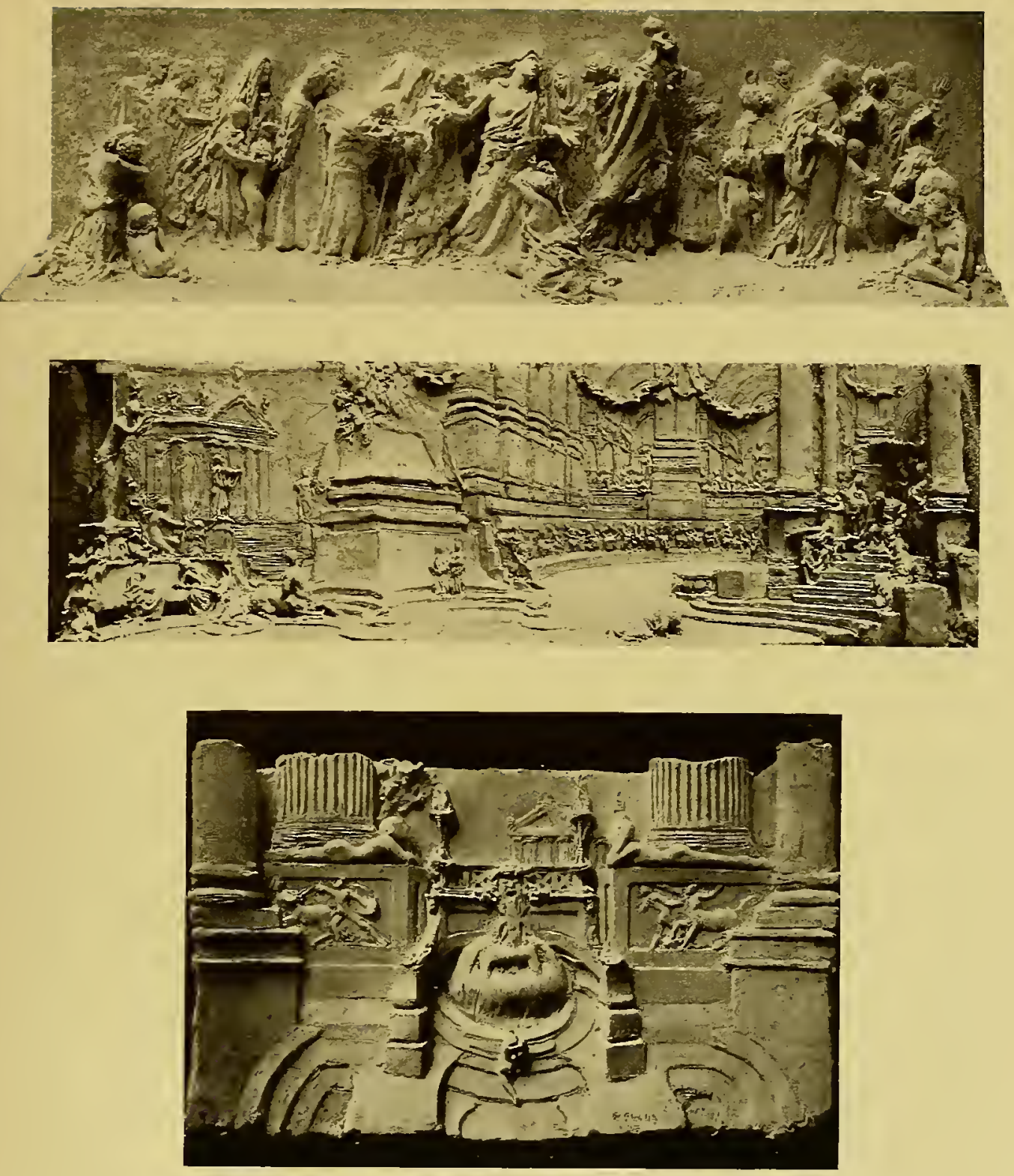

-Bas Relief on Base of Group "ivother's Love" See Frontispiece 


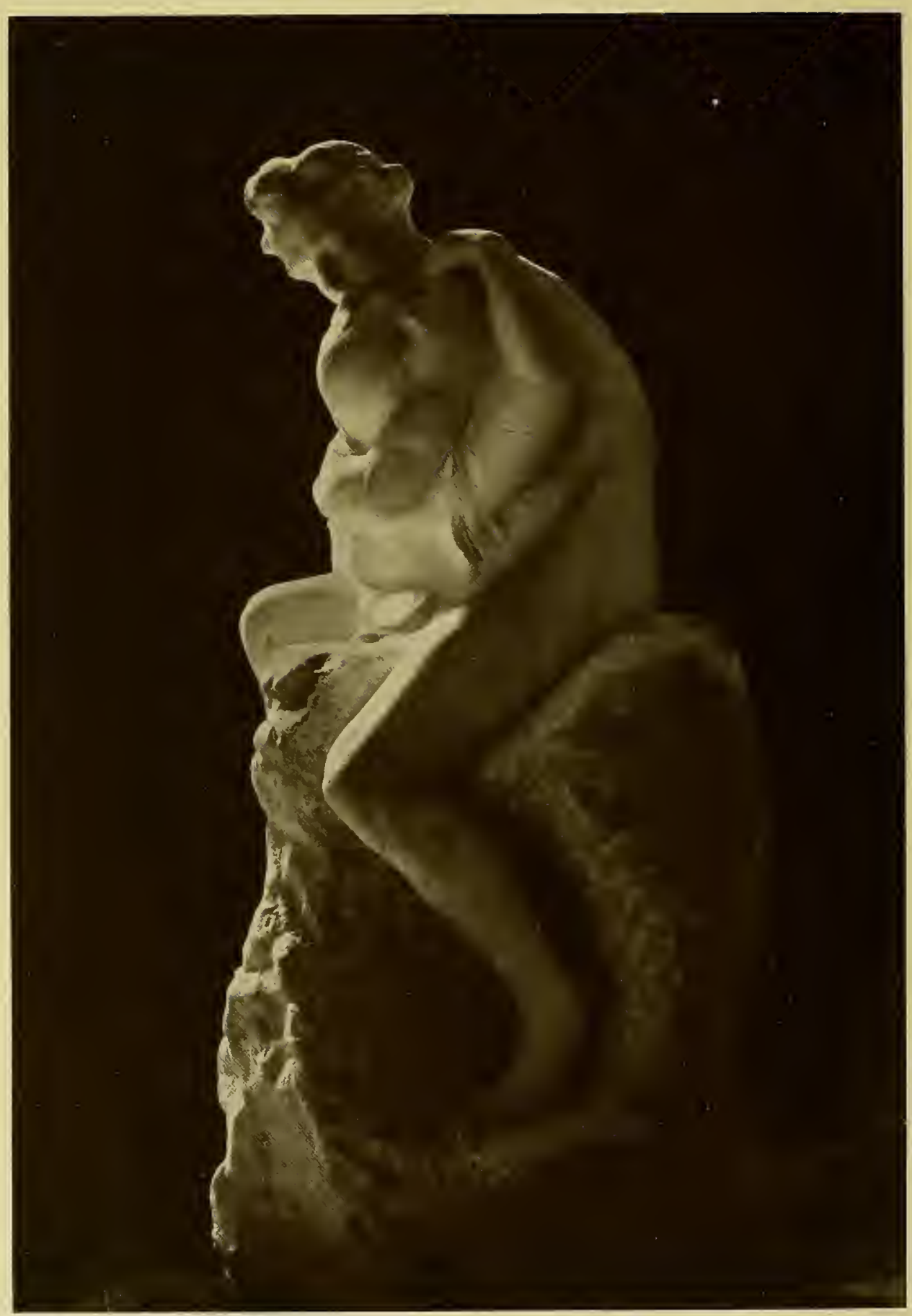

T be Group

But where Strength and Tenderness L'nite, there sound the truest Harmonies 


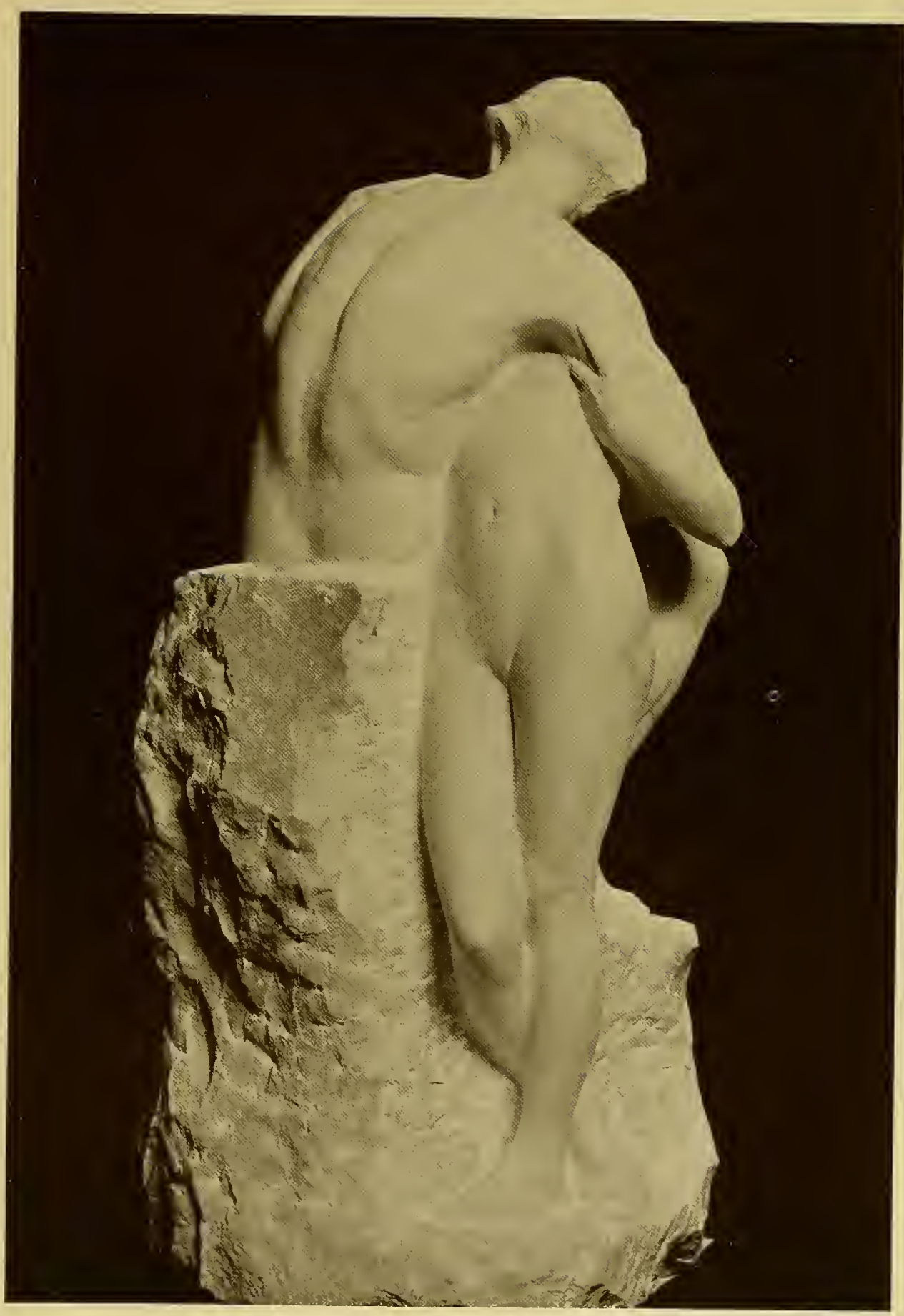

The Group 


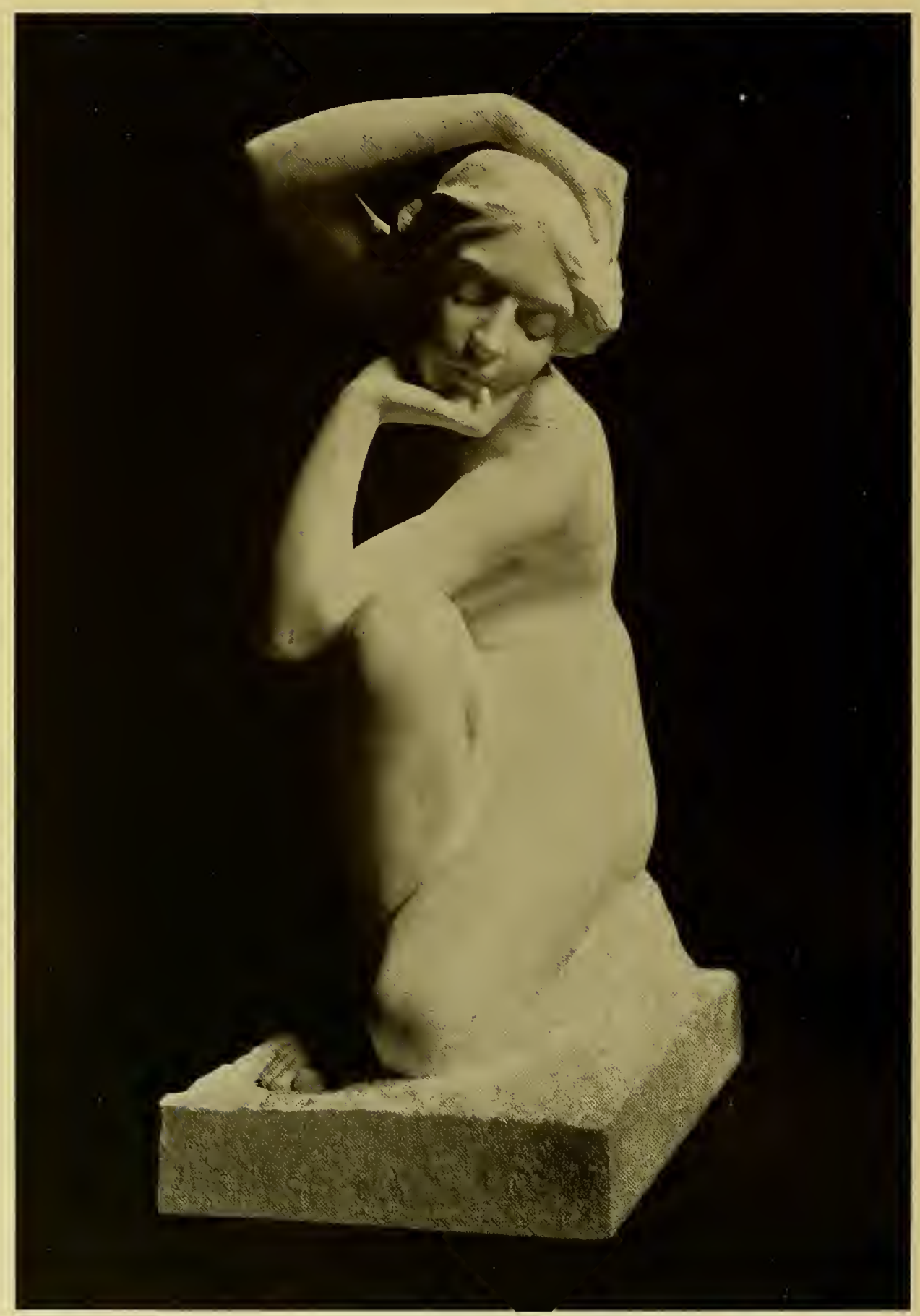

Maiden Meditation 


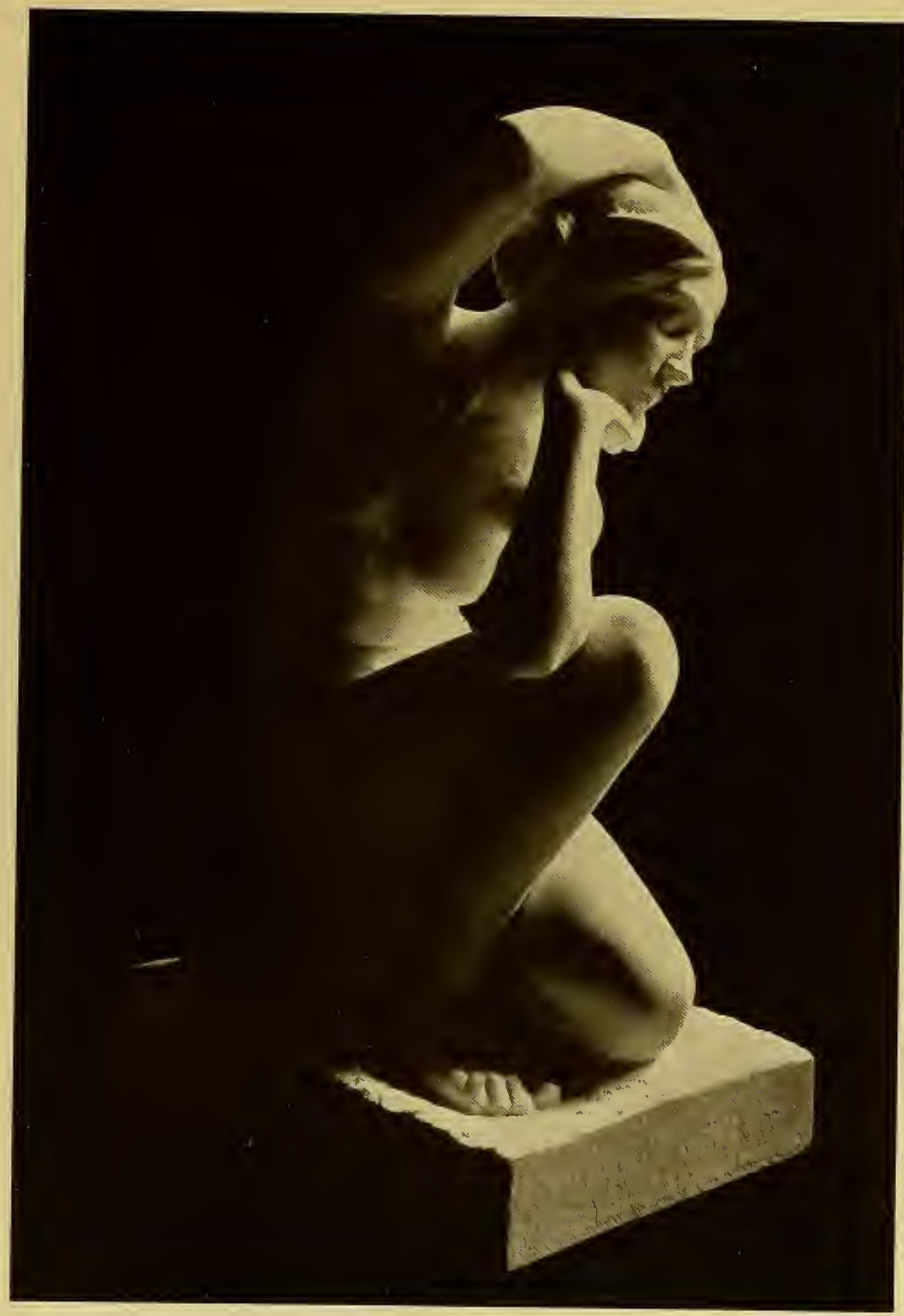

Maiden Meditation 


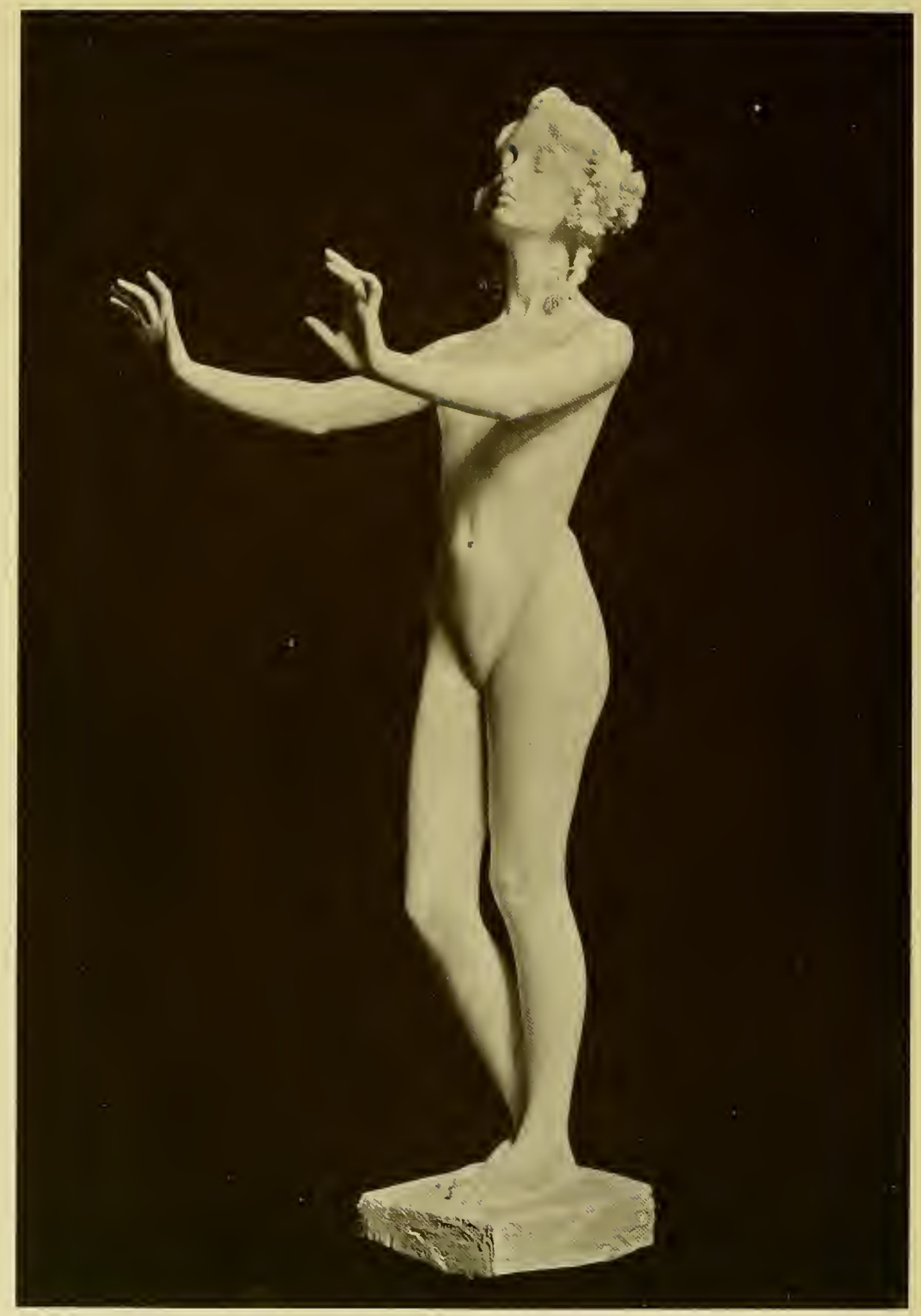

T be Call from 'Beyond 


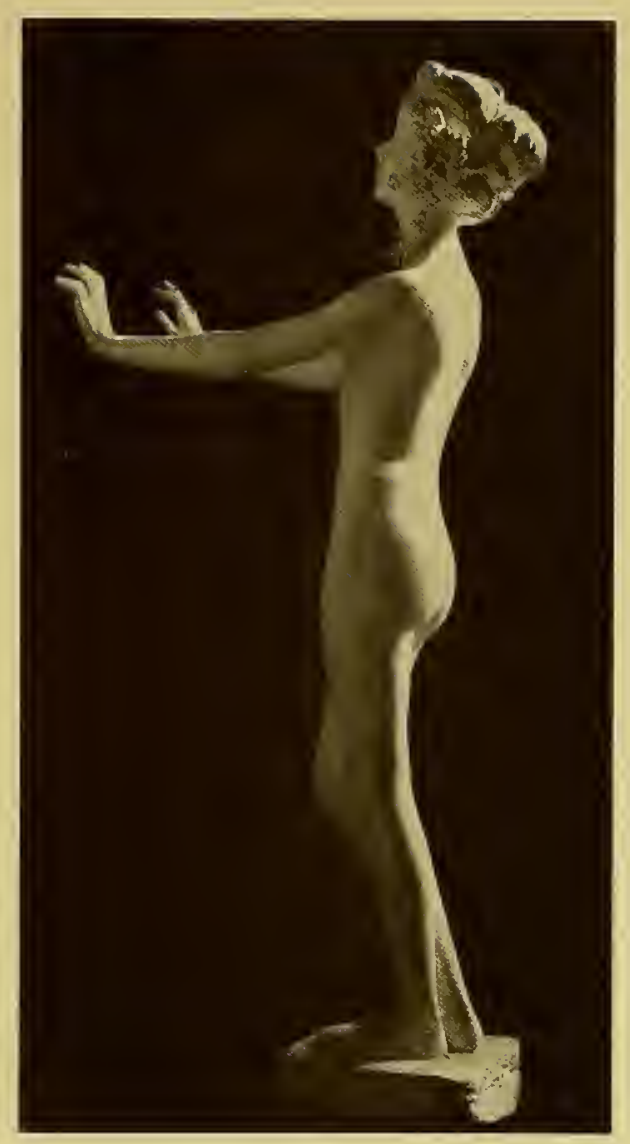

The Call from Beyond

Listen, tbrougb the woodland valleys,

Comes a wbisper to my ear,

Like some fairy-voices calling,

From a wondrous bigher spbere.

Calling softly, ever softly;

Let me follow, ob my beart,

For a tale of mystic beauty.

Wby tbis world is but a part.

Let me follow and respond,

To "the calling from beyond." 


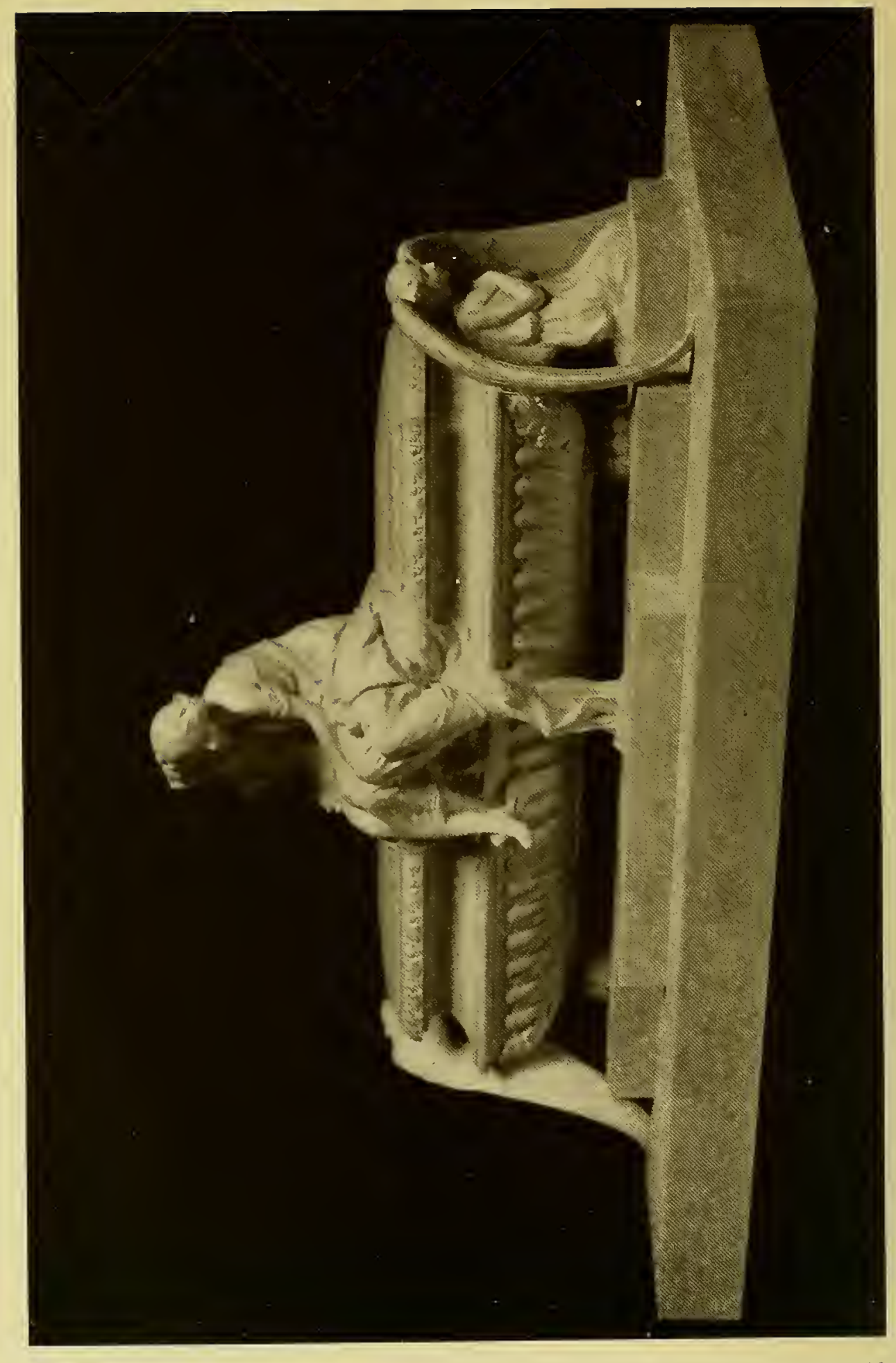


The Sisters

MEMORIAL IN MARBLE IN THE WALKER ART GALLER Y-LIVERPOOL 


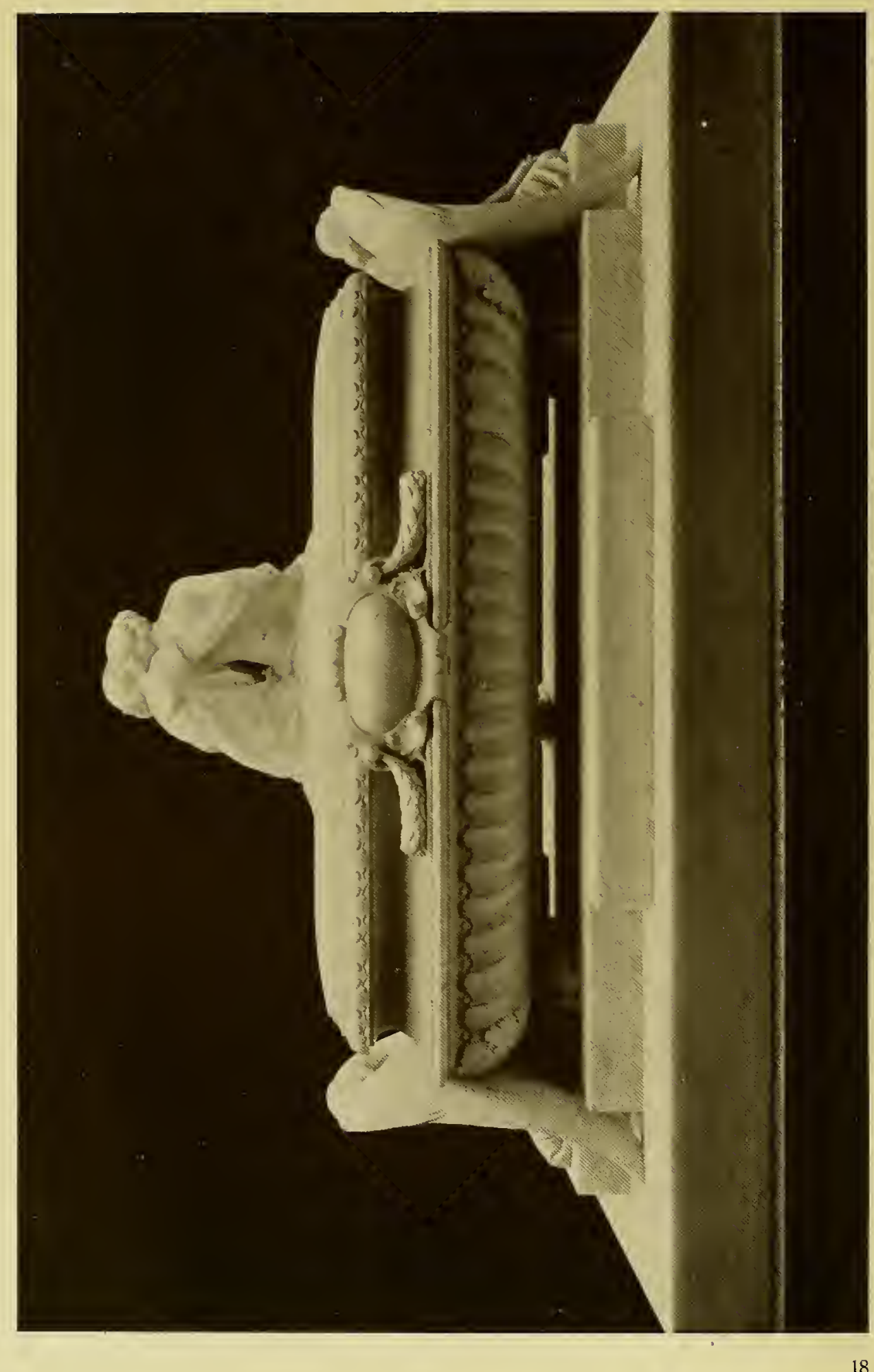


The Sisters

MEMORIAL IN MARBLE IN THE WALKER ART GALLERY-LIVERPOOL 


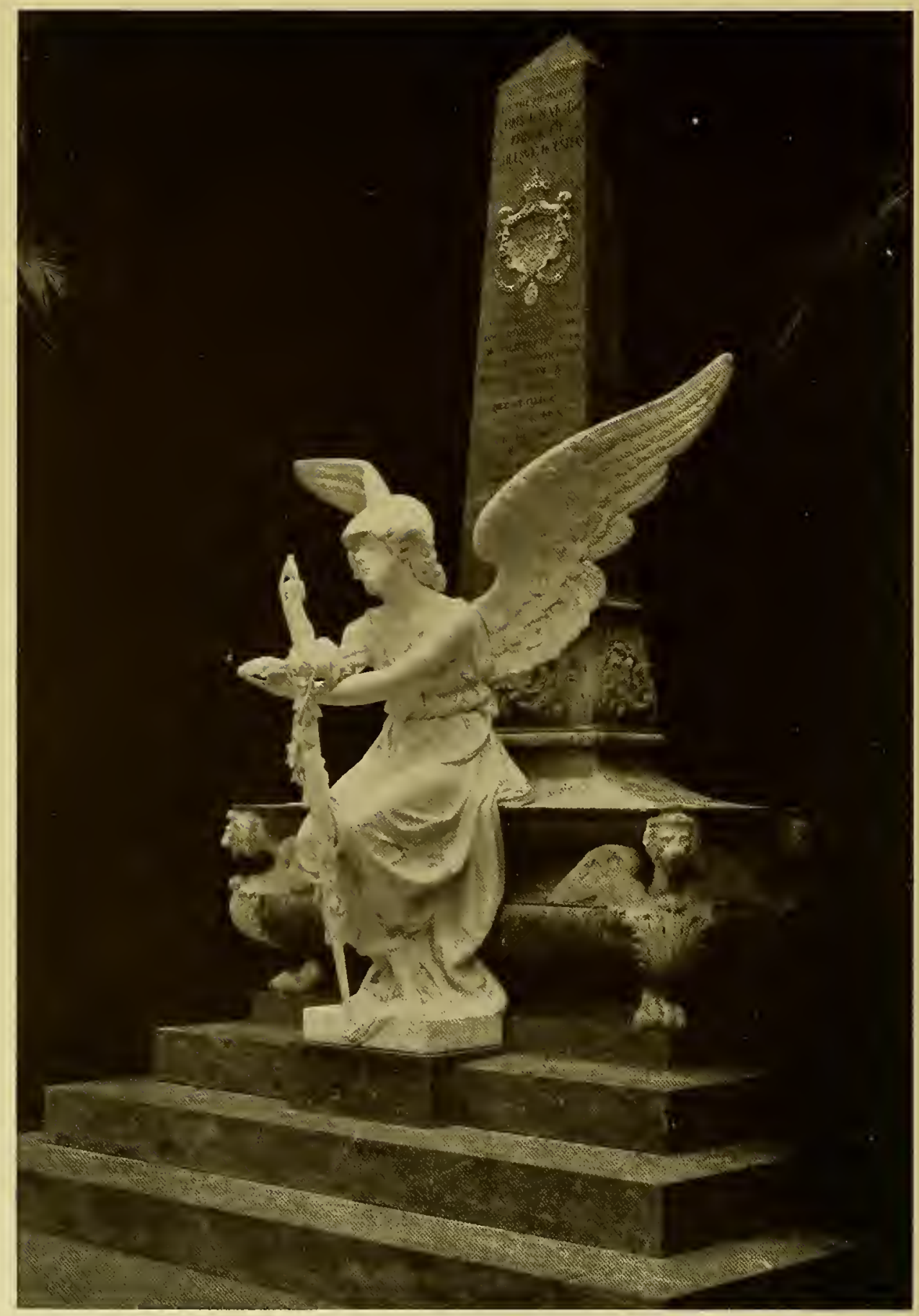

Prince Cbristian Memorial

ERECTED AT THE ROYAL CHAPEL IN WINDSOR EXECUTED FOR QUEEN VICTORIA 


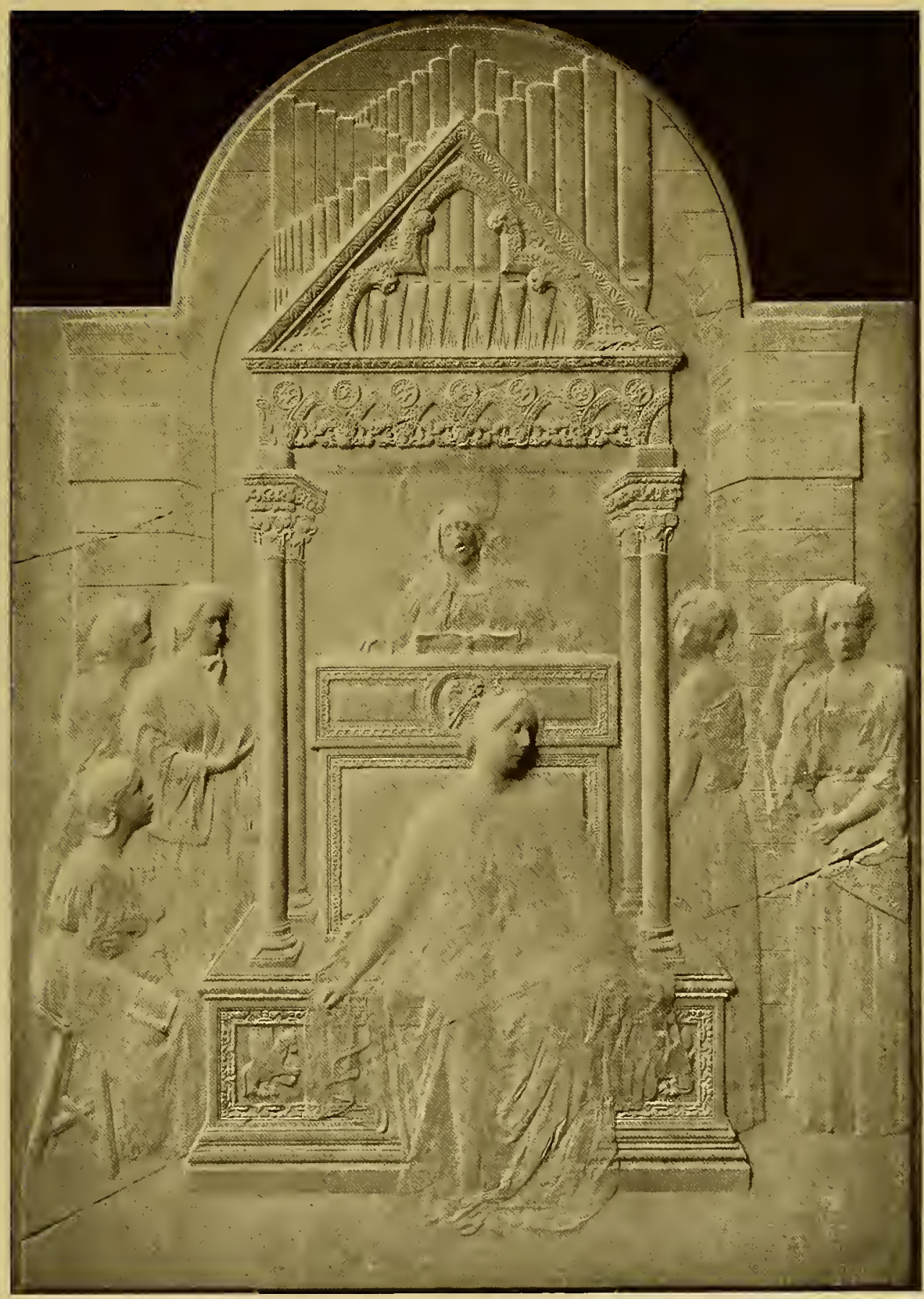

Sancta Cecilia

IN THE COLLECTION OF EDWARD D. ADAMS, ESQ. 


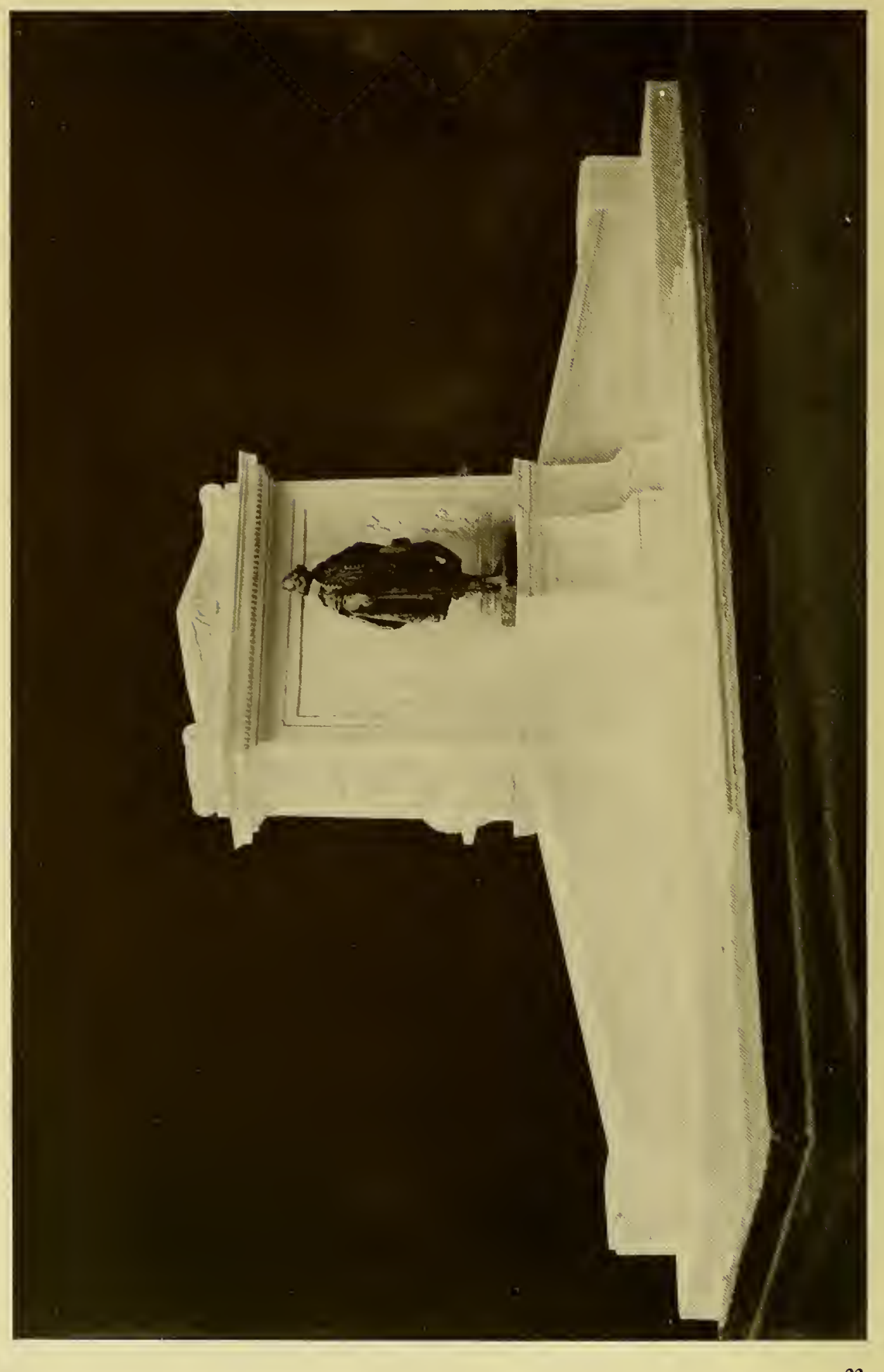


Design for a Cbamplain Nemorial 


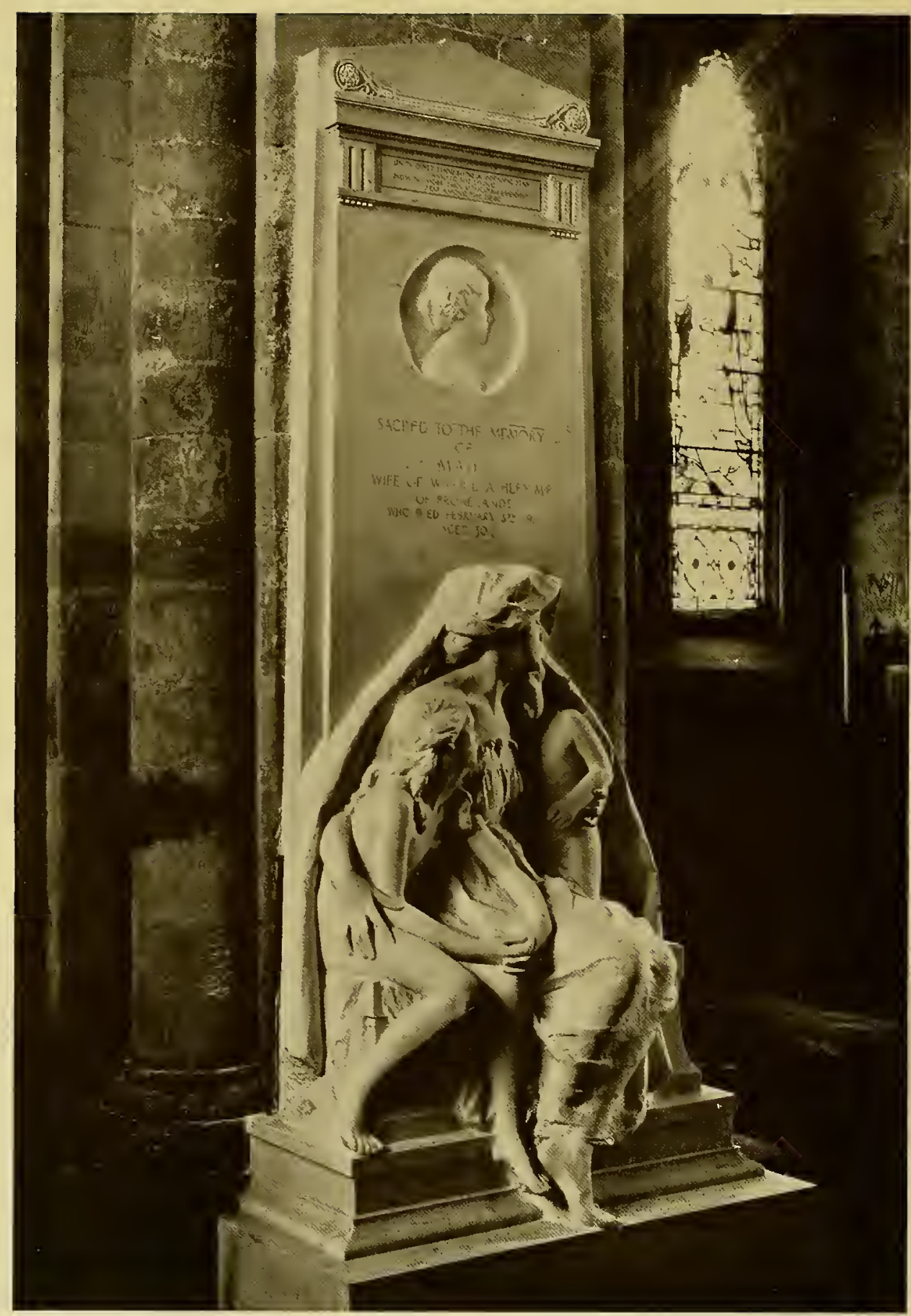

Asbley Memorial at Ramsey Catbedral

"Once didst tbou sbine a morning star amongst tbe living. Now, no more, thou sbinest an evening star among the dead." 


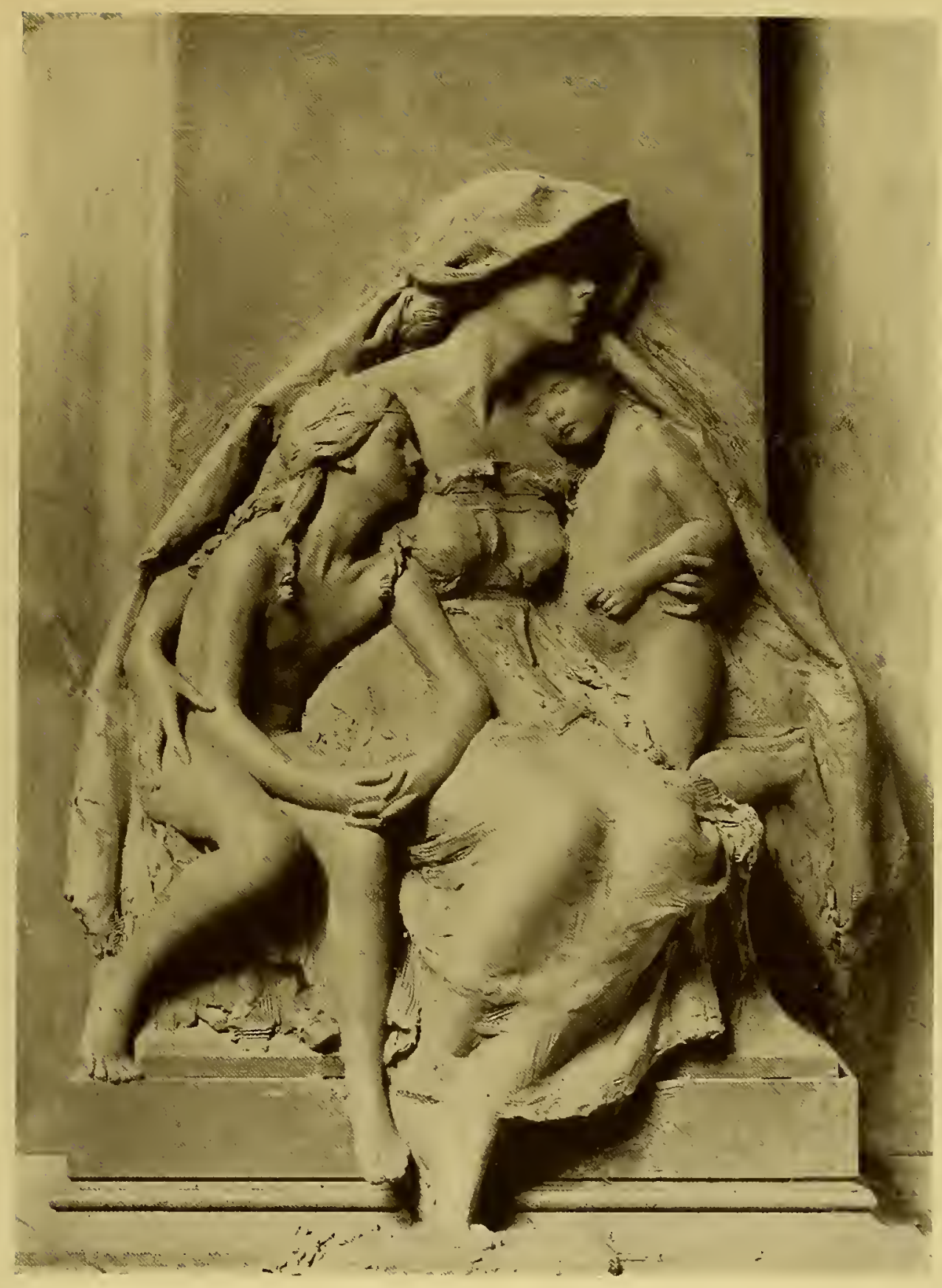

- Details of the Asbley MTemorial 


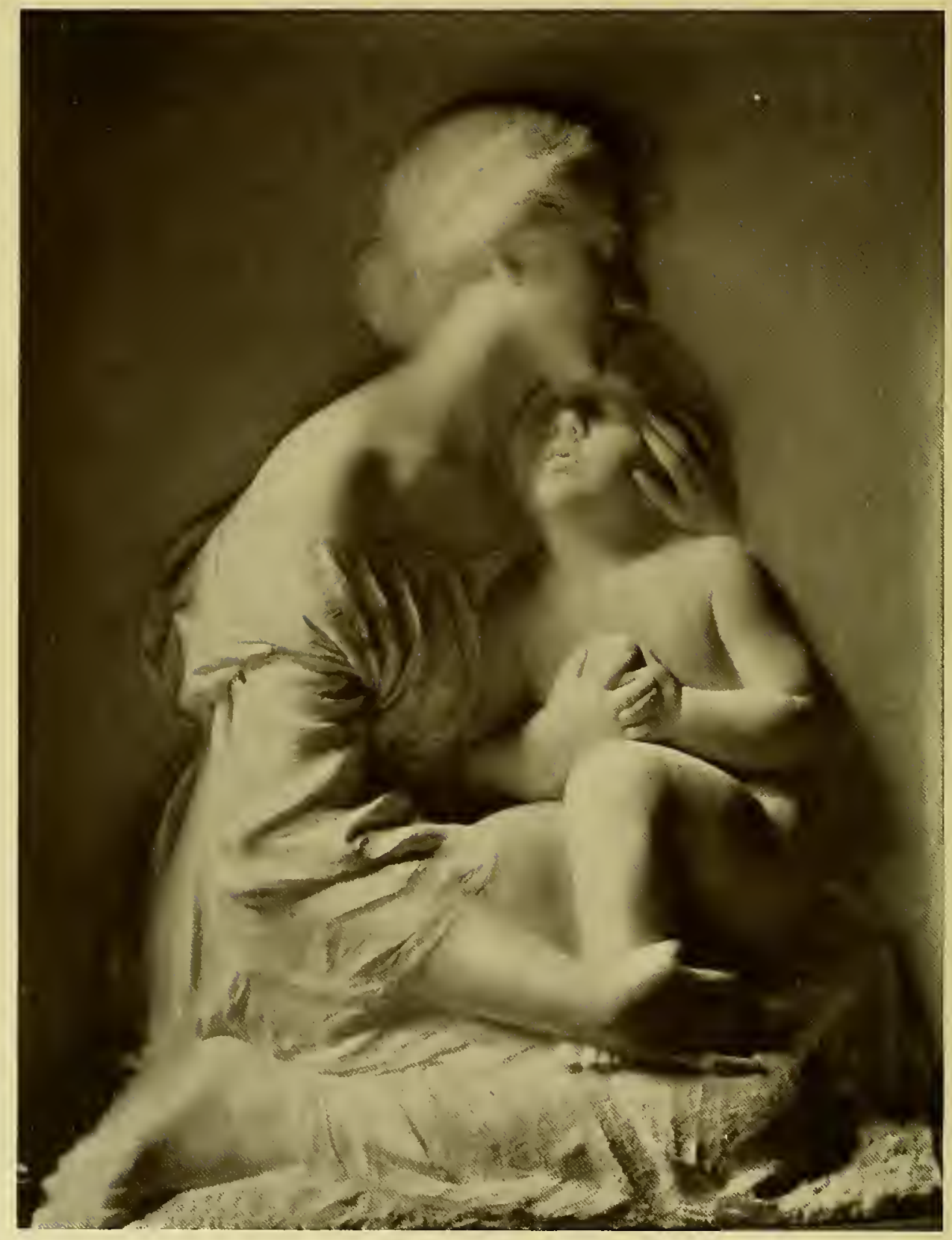

ETother and Child 


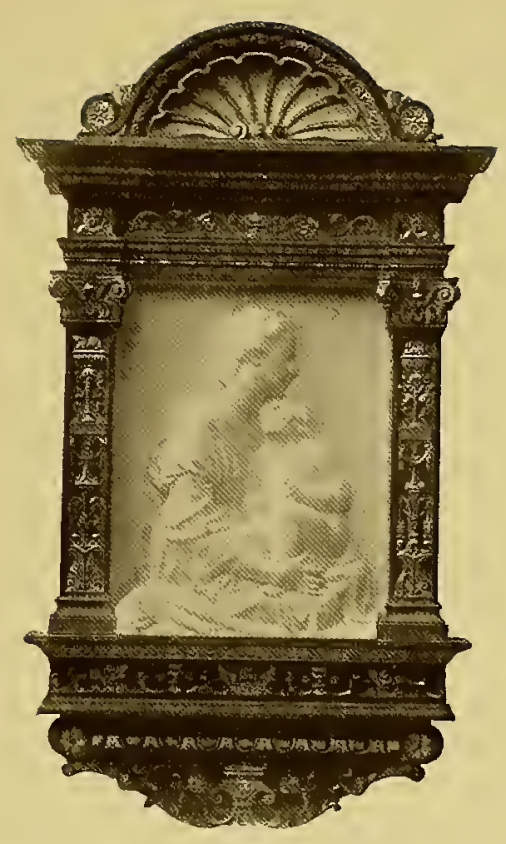




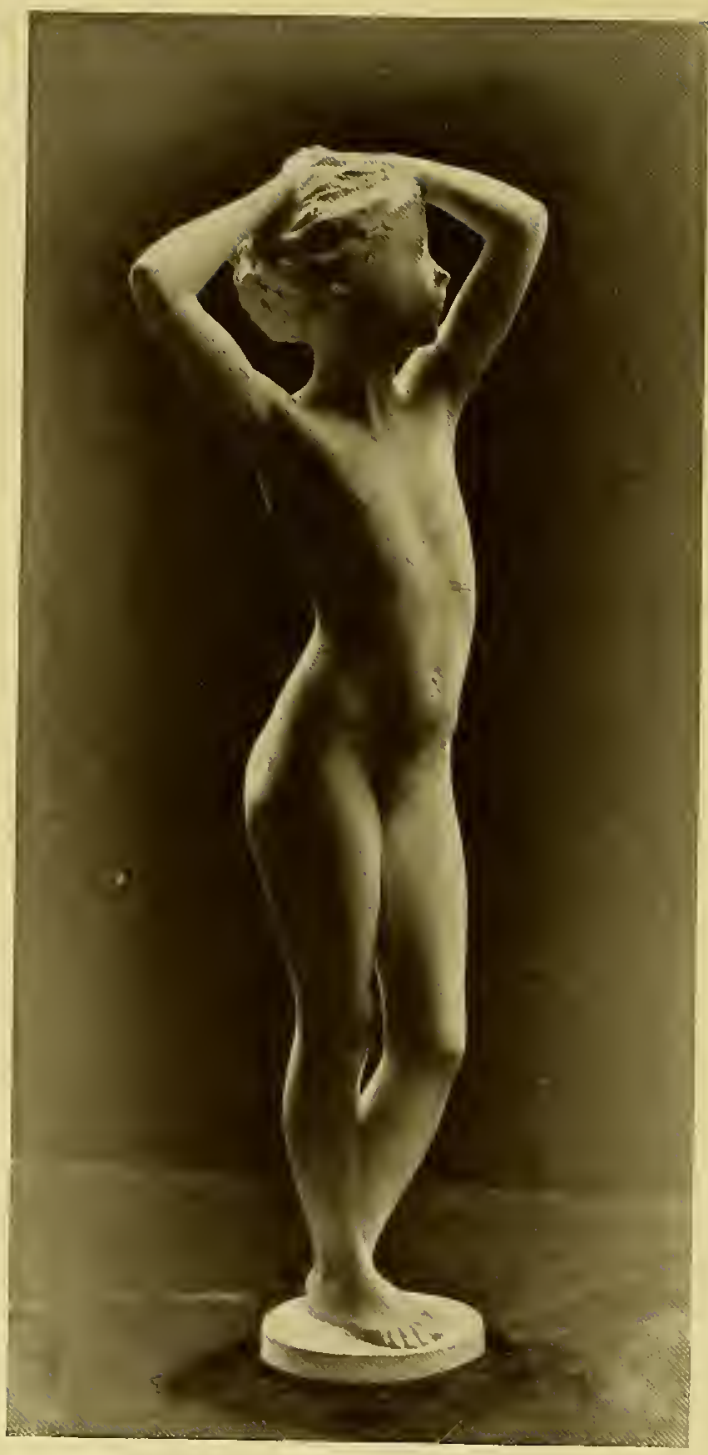

Study of a N cude BRONZE

In the Cleveland Or Iusen of $\mathrm{At}$ 

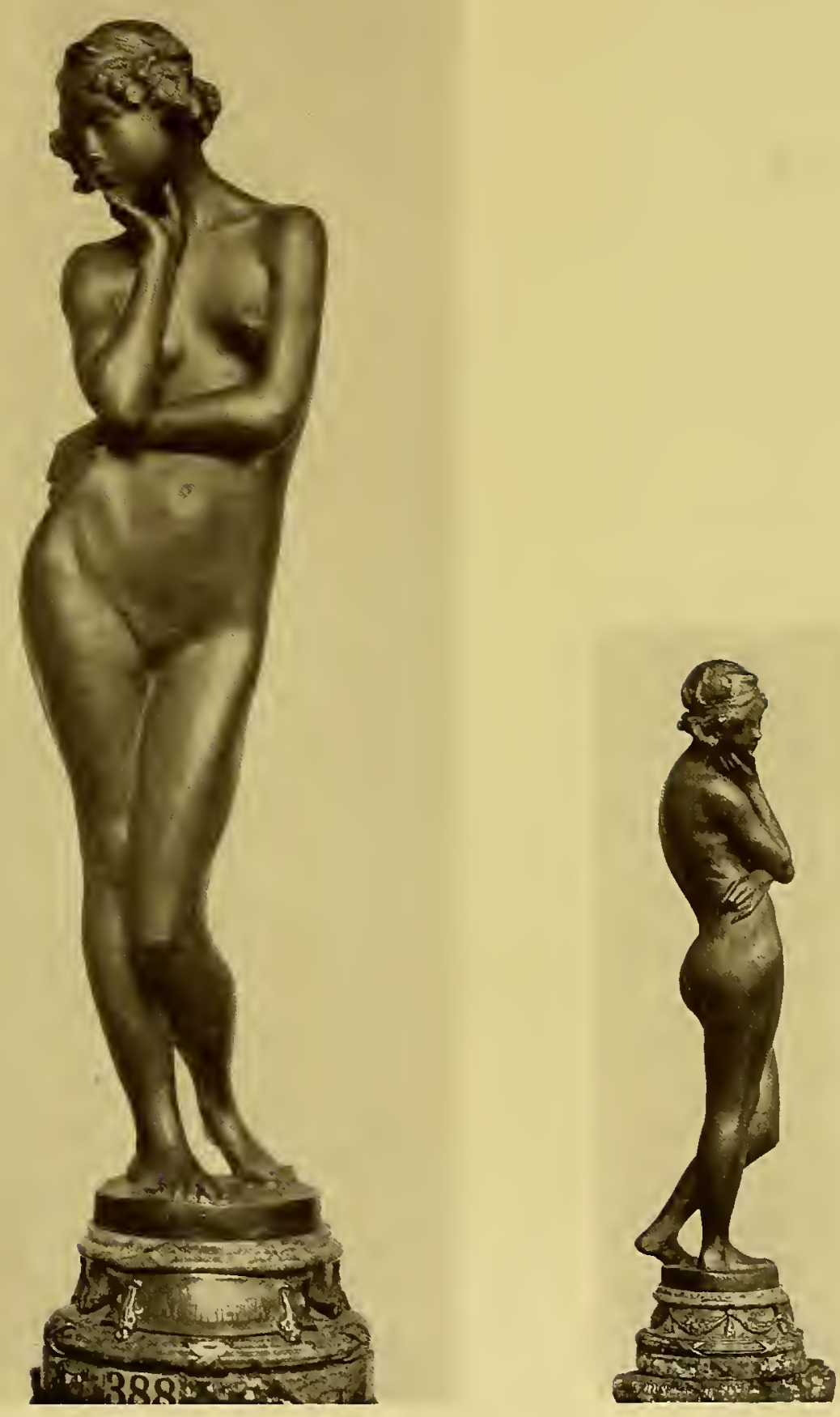

La Pensierosa

BRONZE 

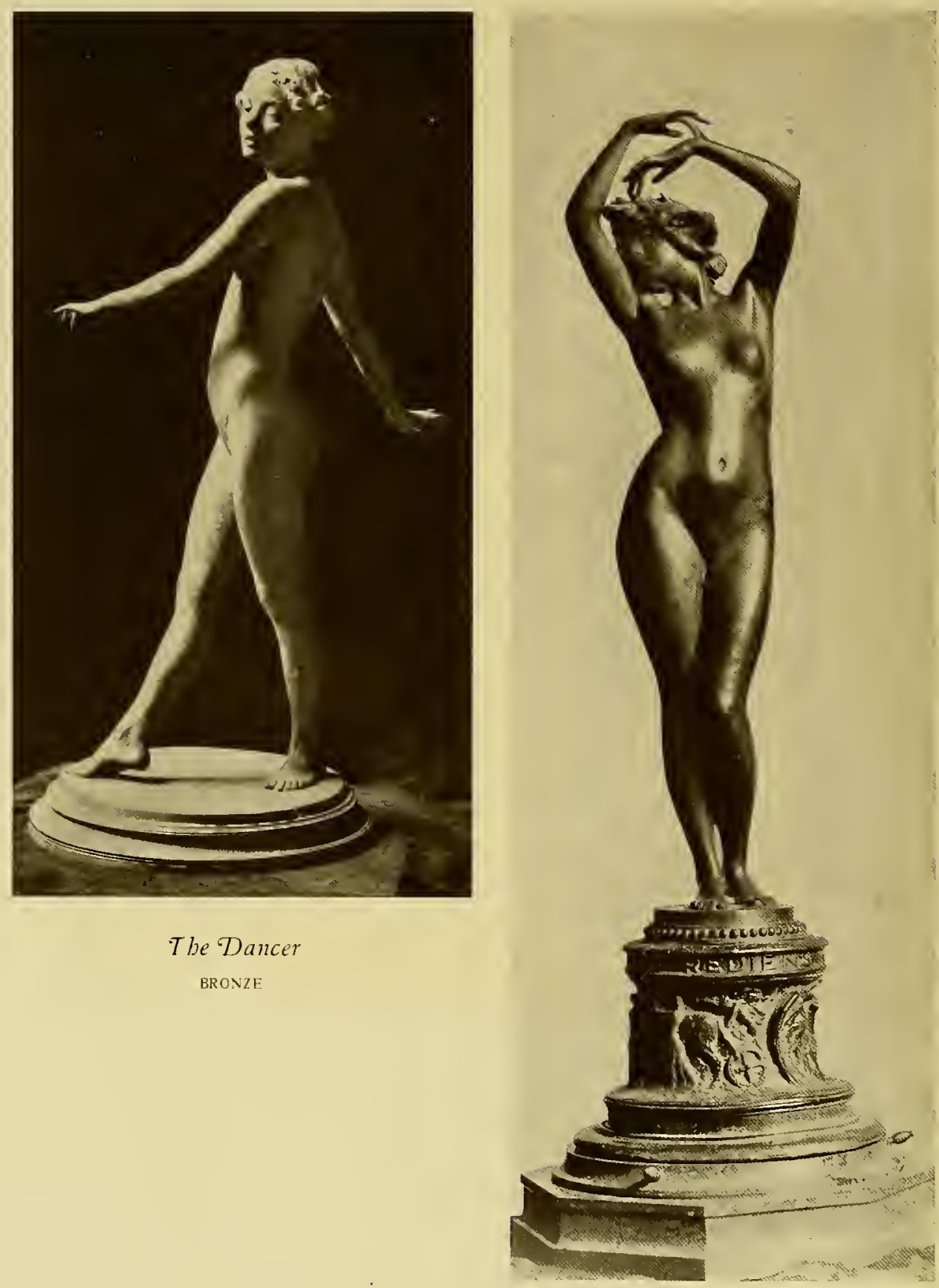

- Dawn

BRONZE 


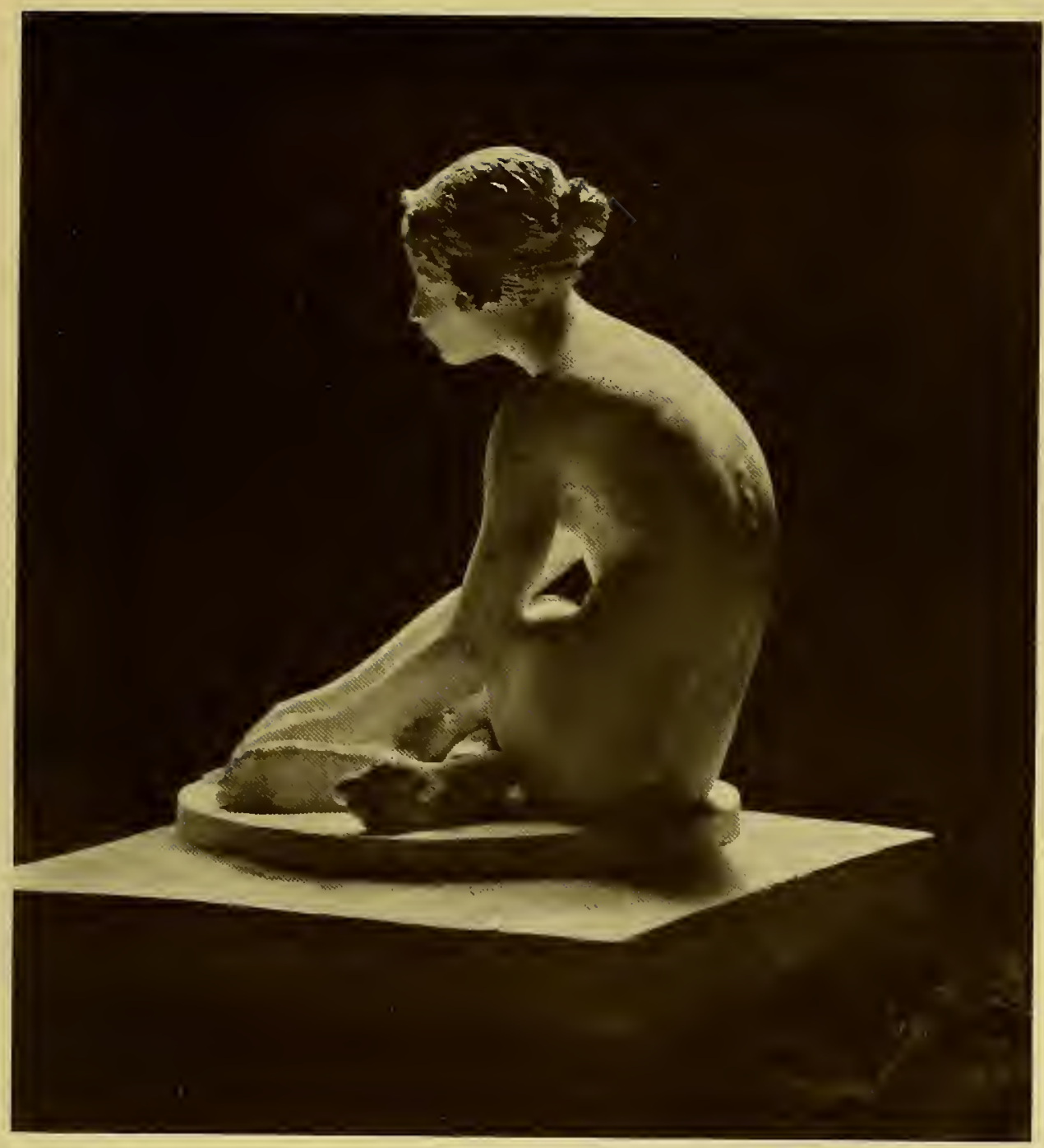

dremories

BRONZE 


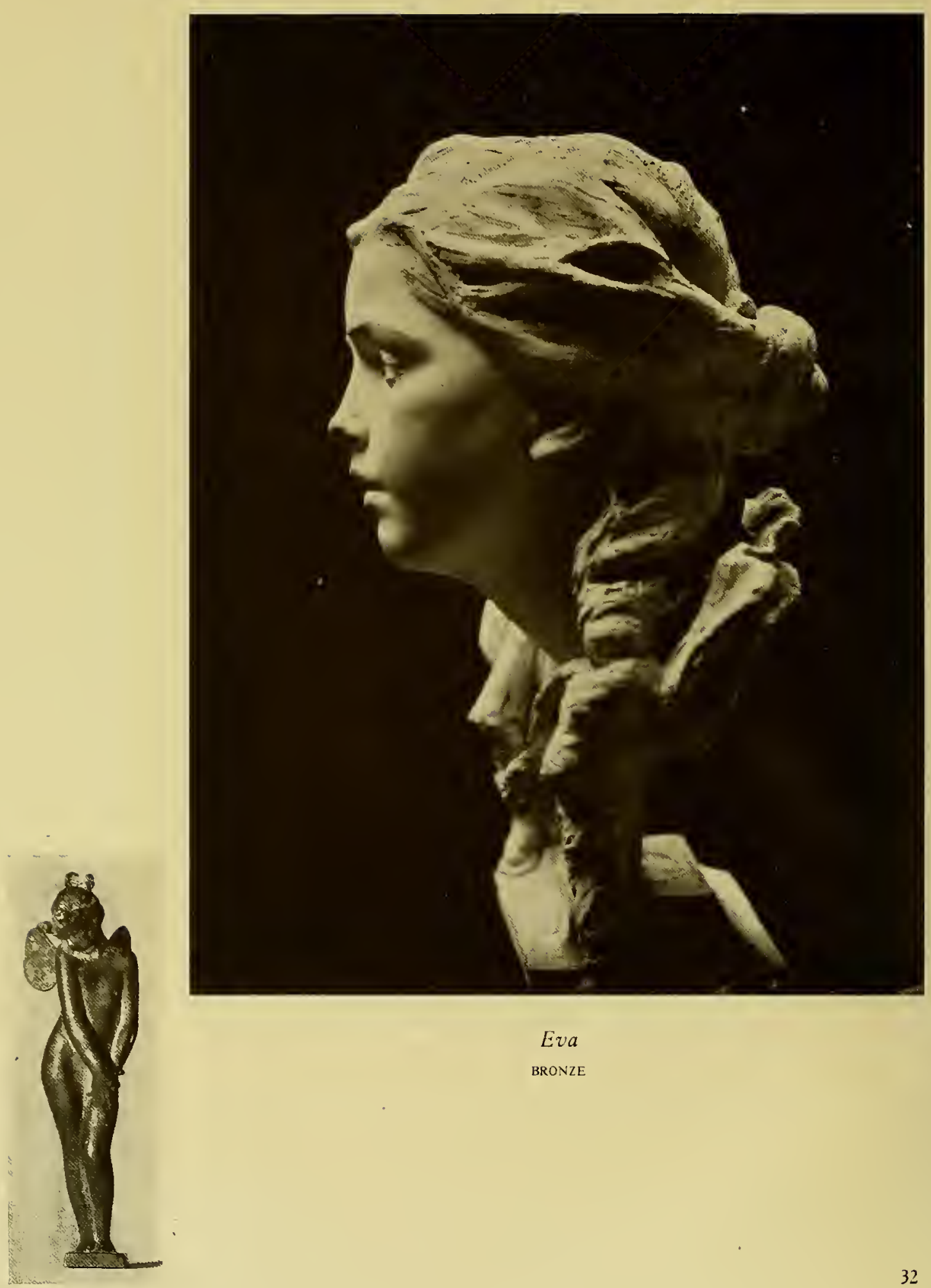




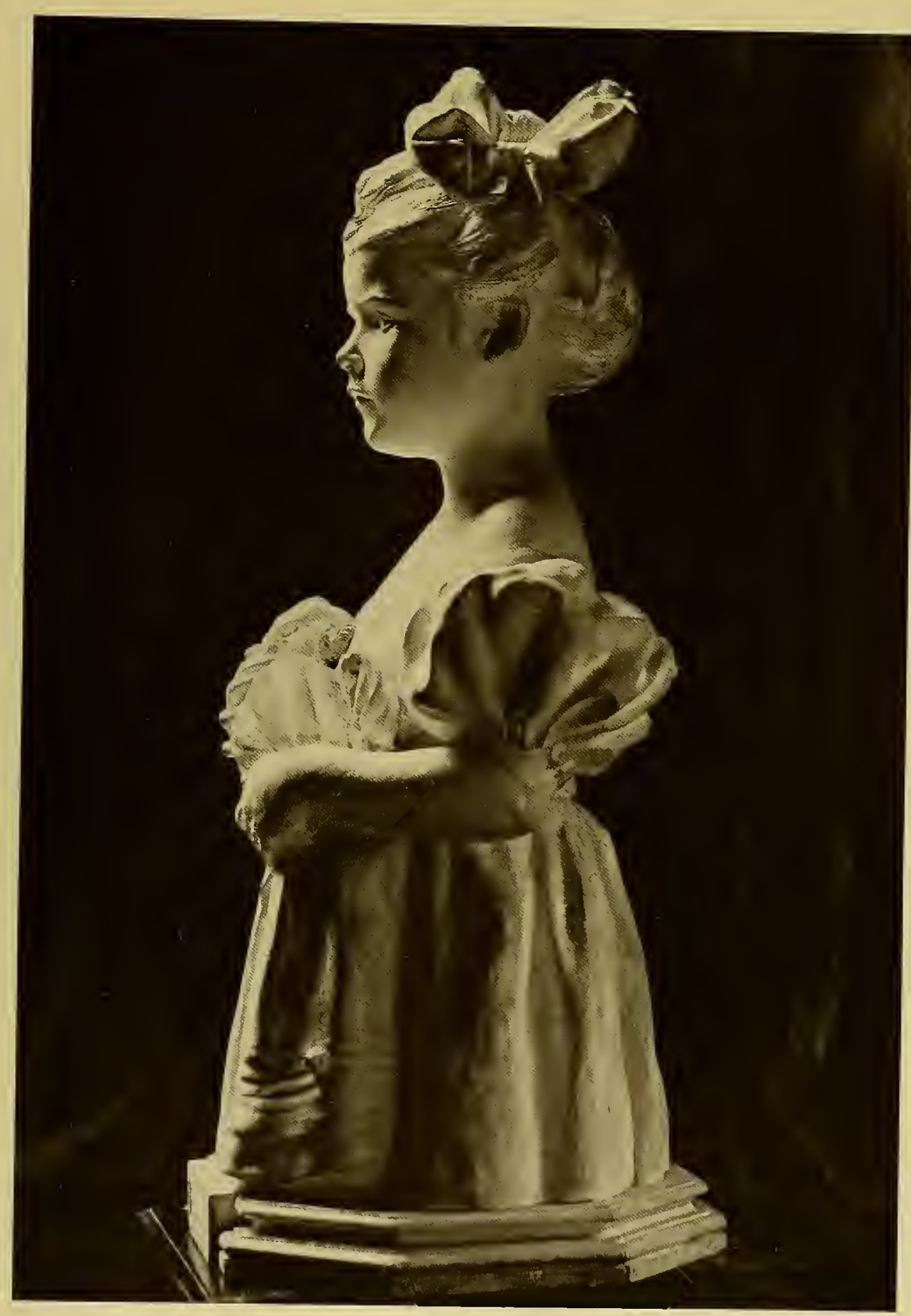

\section{Betty}

MARBLE 

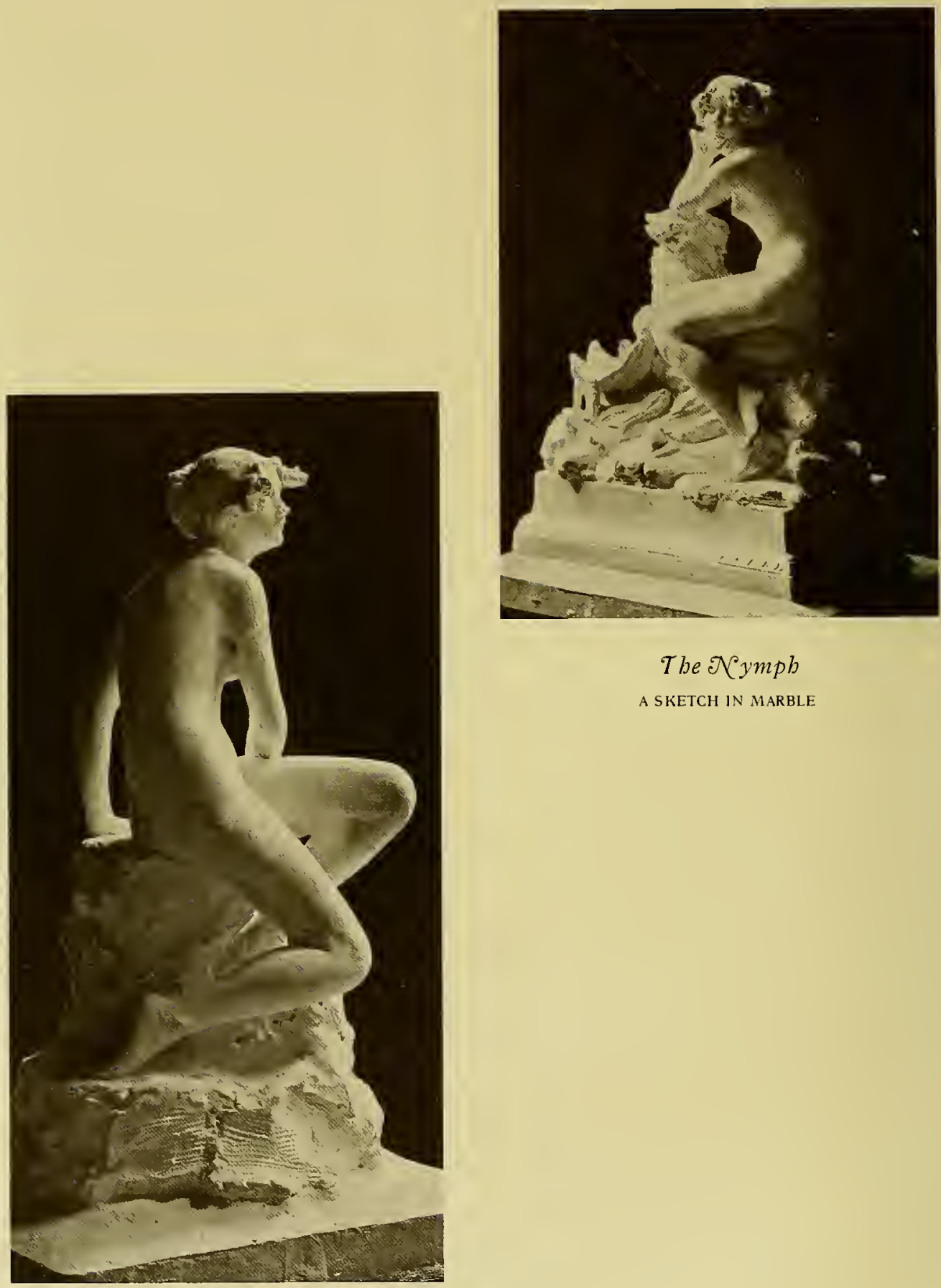

The Xeymph

A SKETCH IN MARBLE

Study

BRONZE 


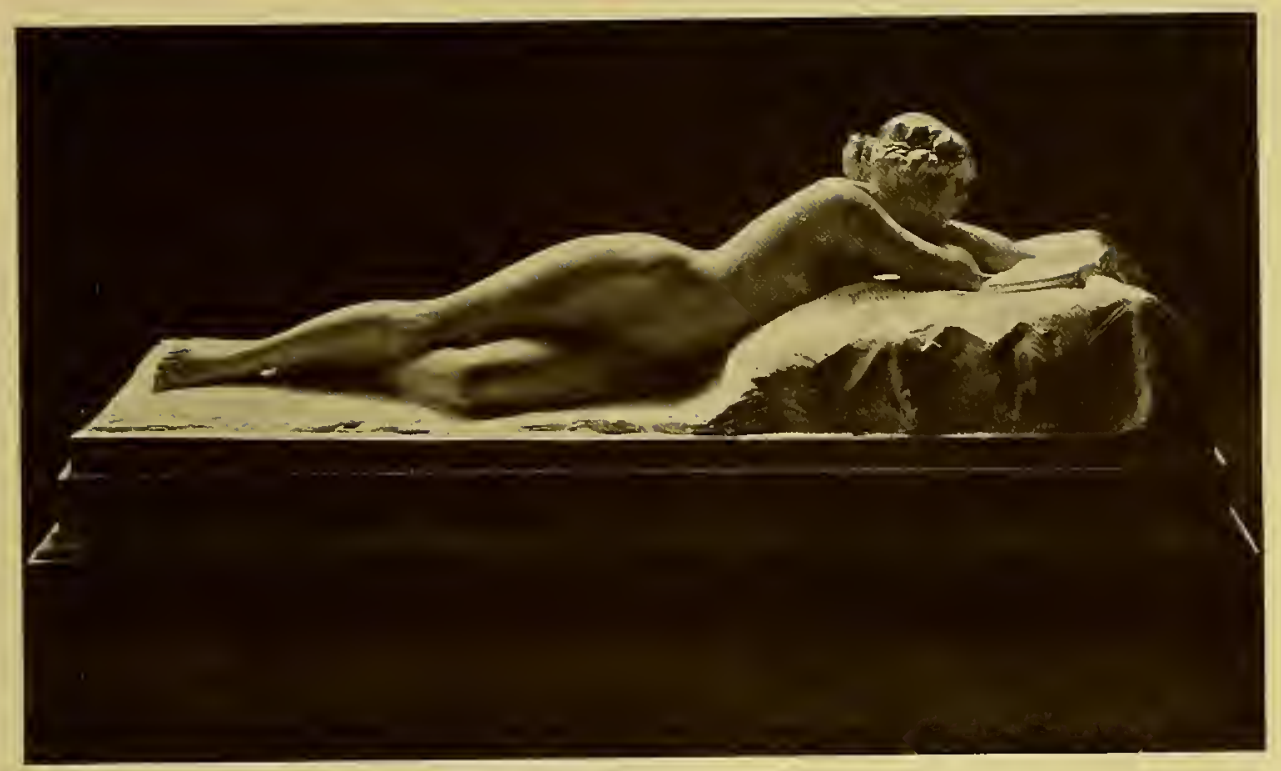

The Reader

MARBLE

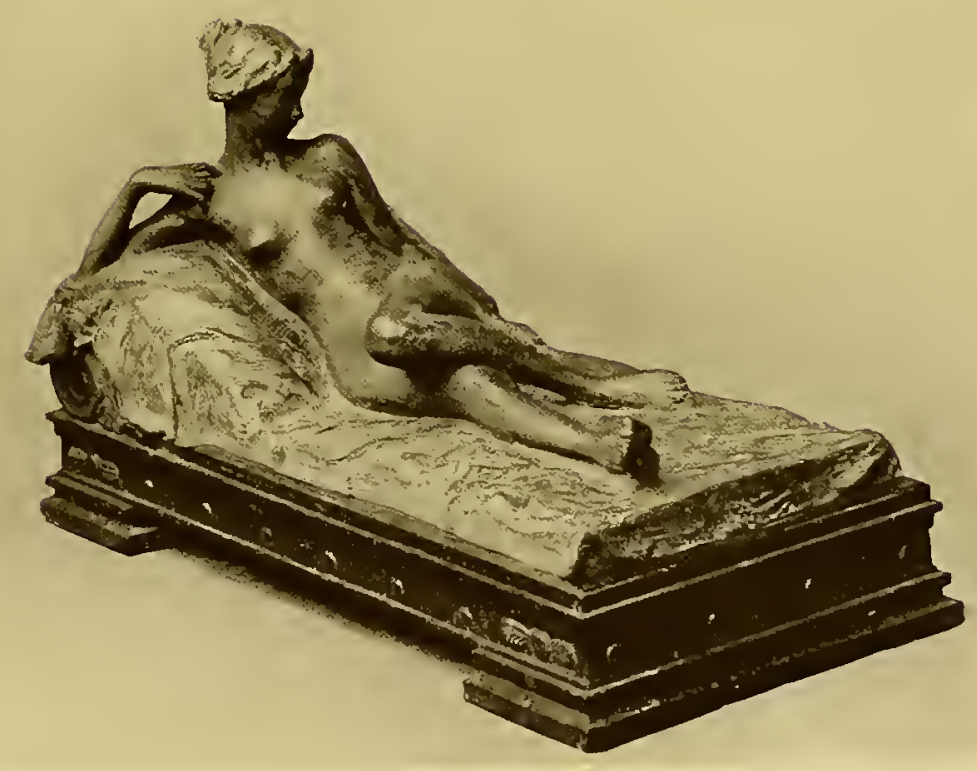

Reclining $\mathcal{X}$ ude

BRONZE 


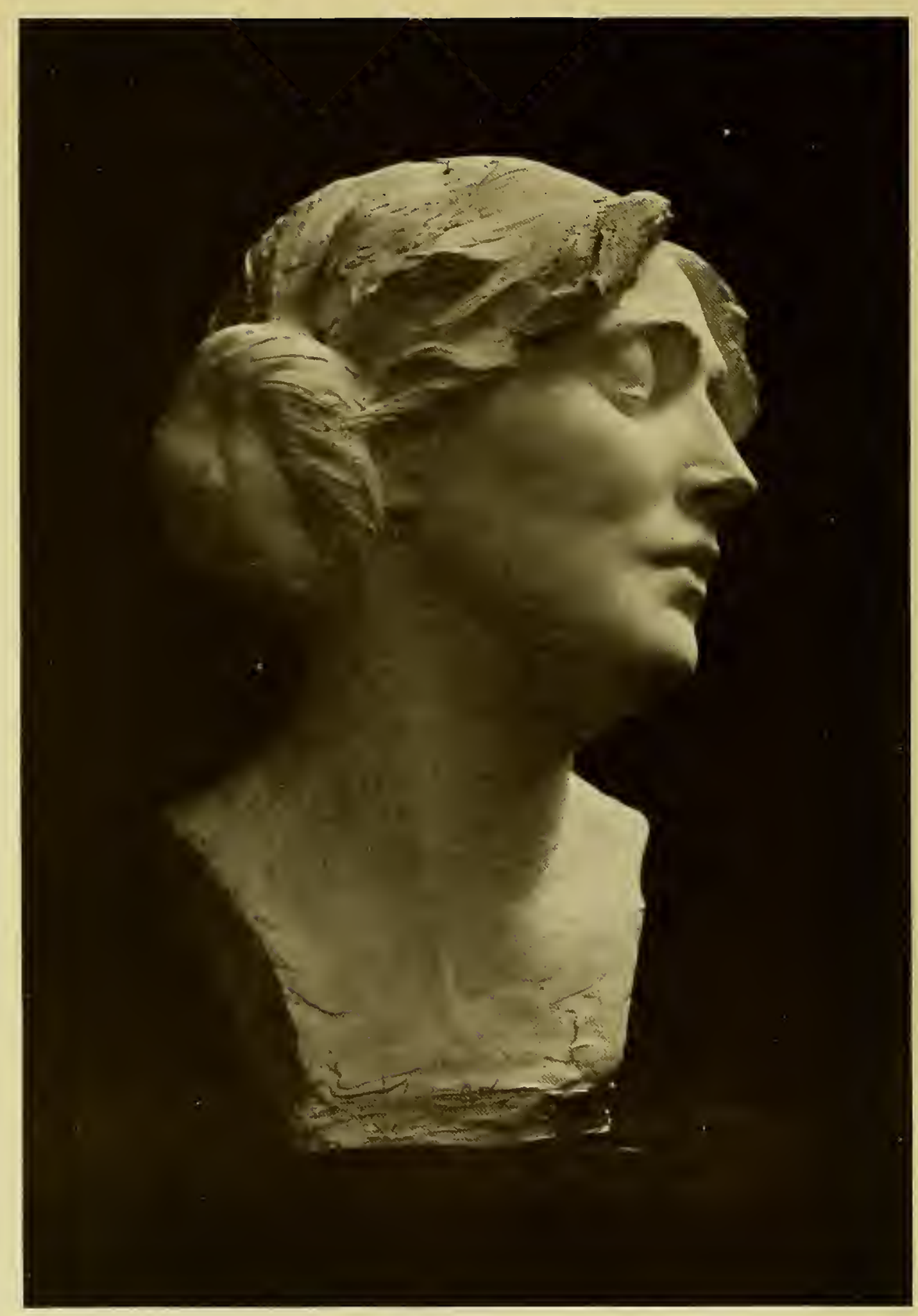

\section{Tamara}

PINK MARBLE 


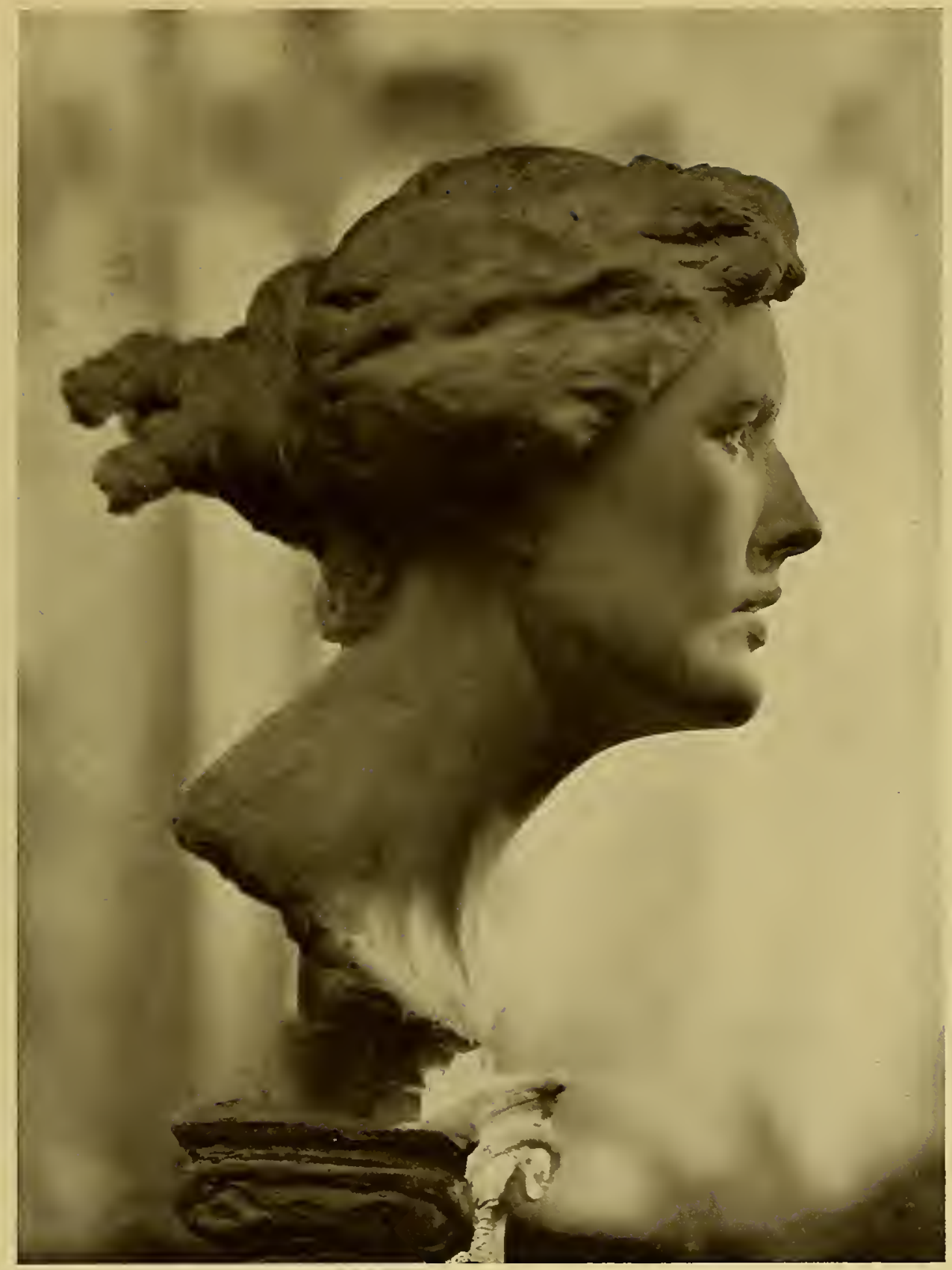

Pbryne

BRONZE 


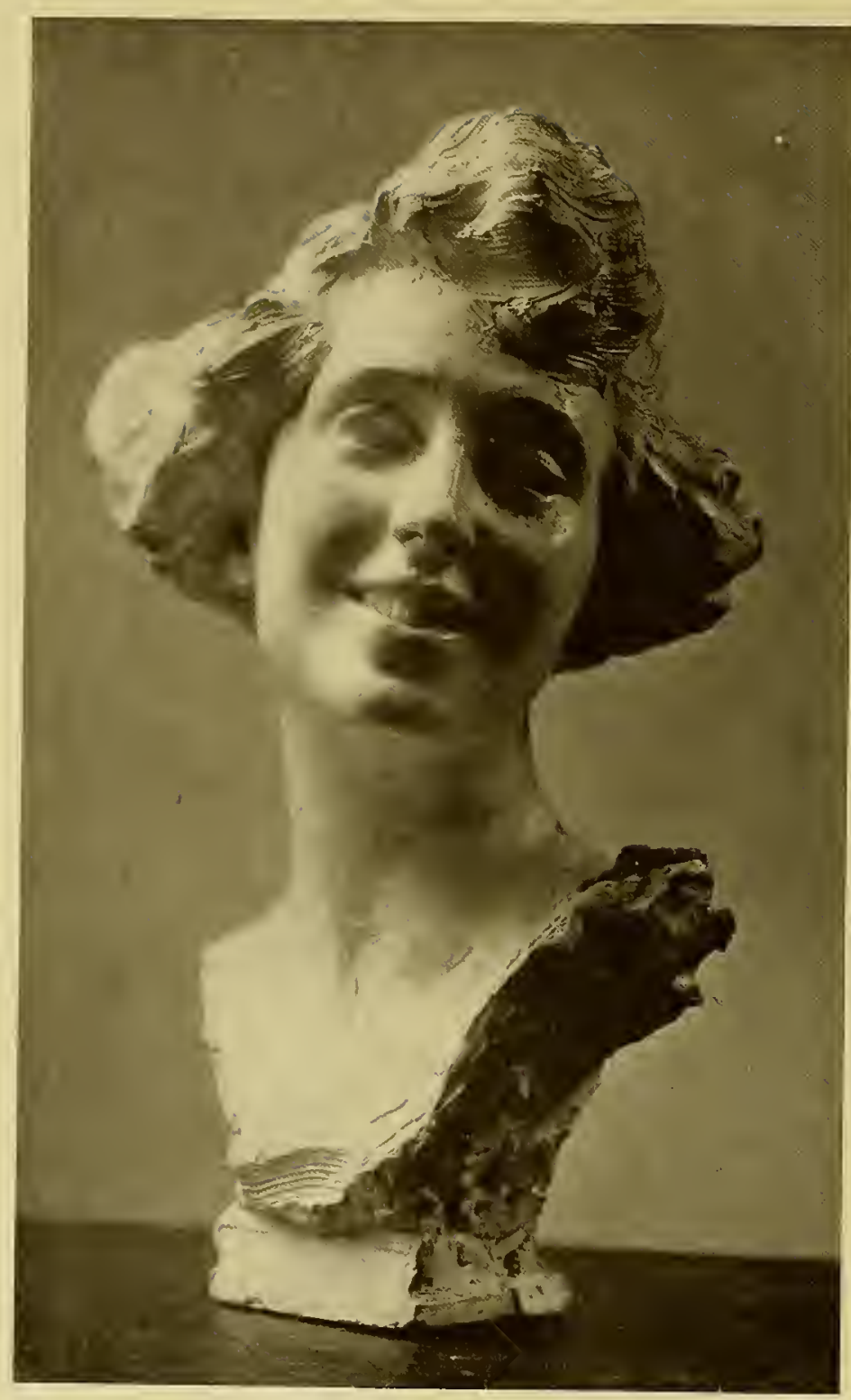

Rita

BRONZE 


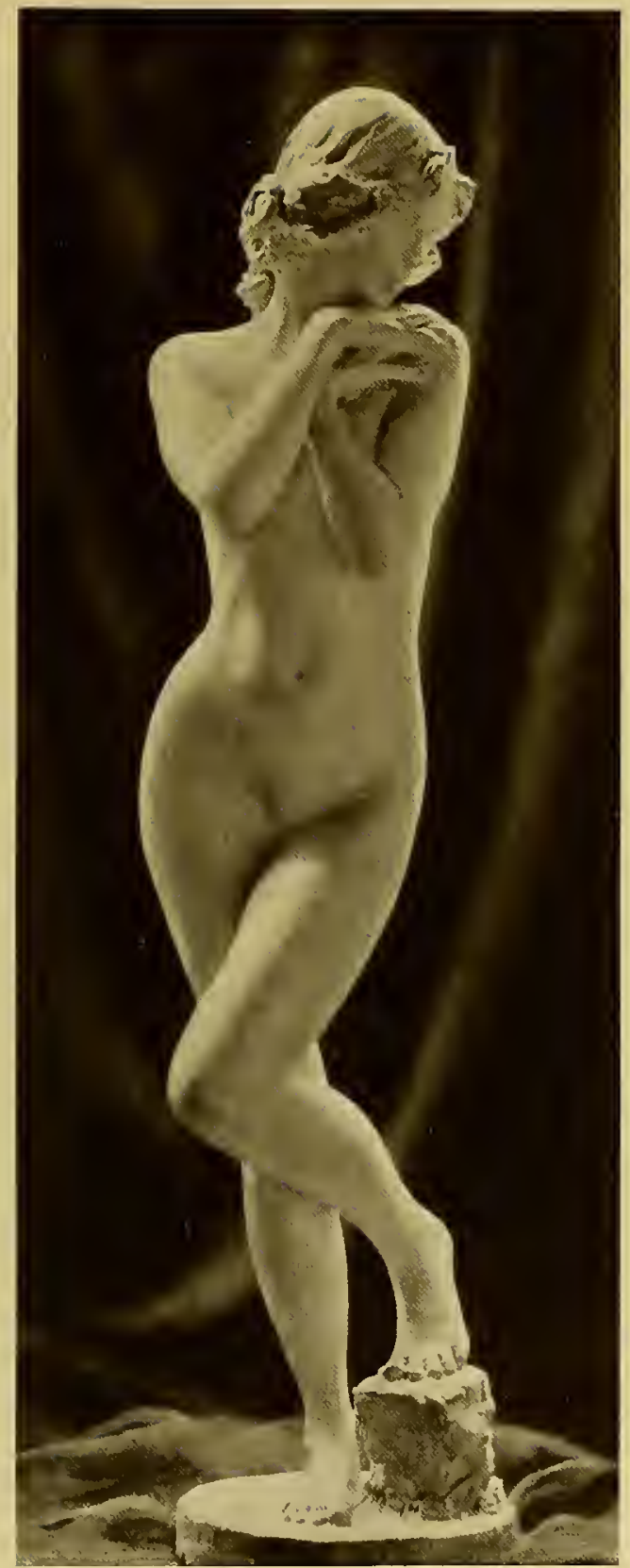

Carmella

BRONZE

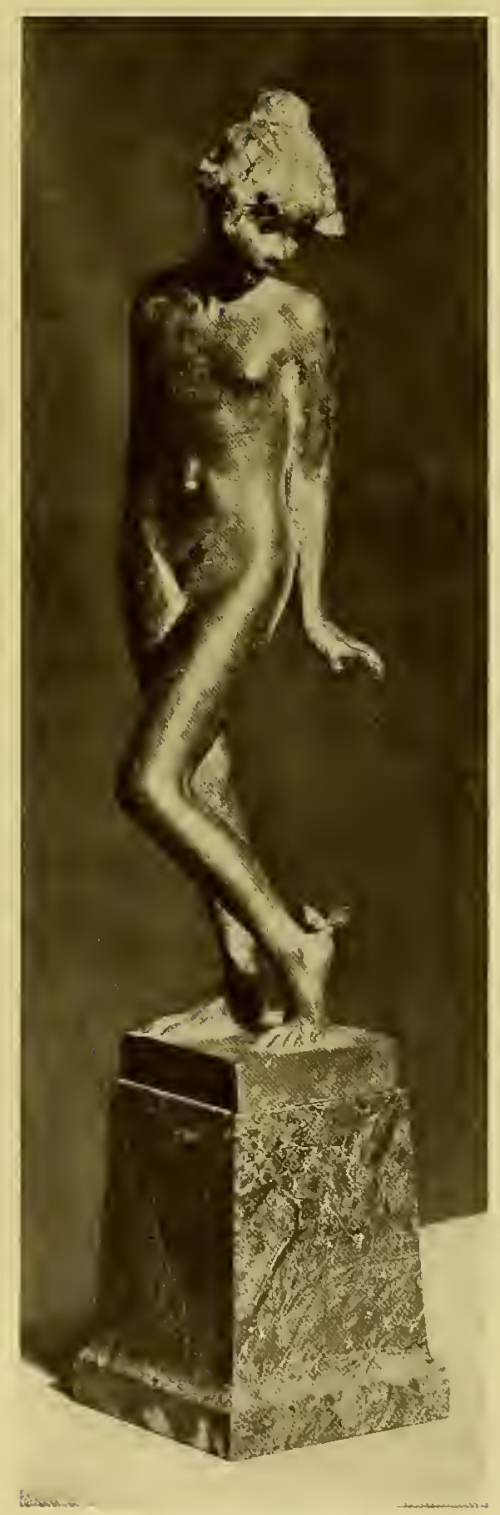

T be Butterfly

BRONZE 


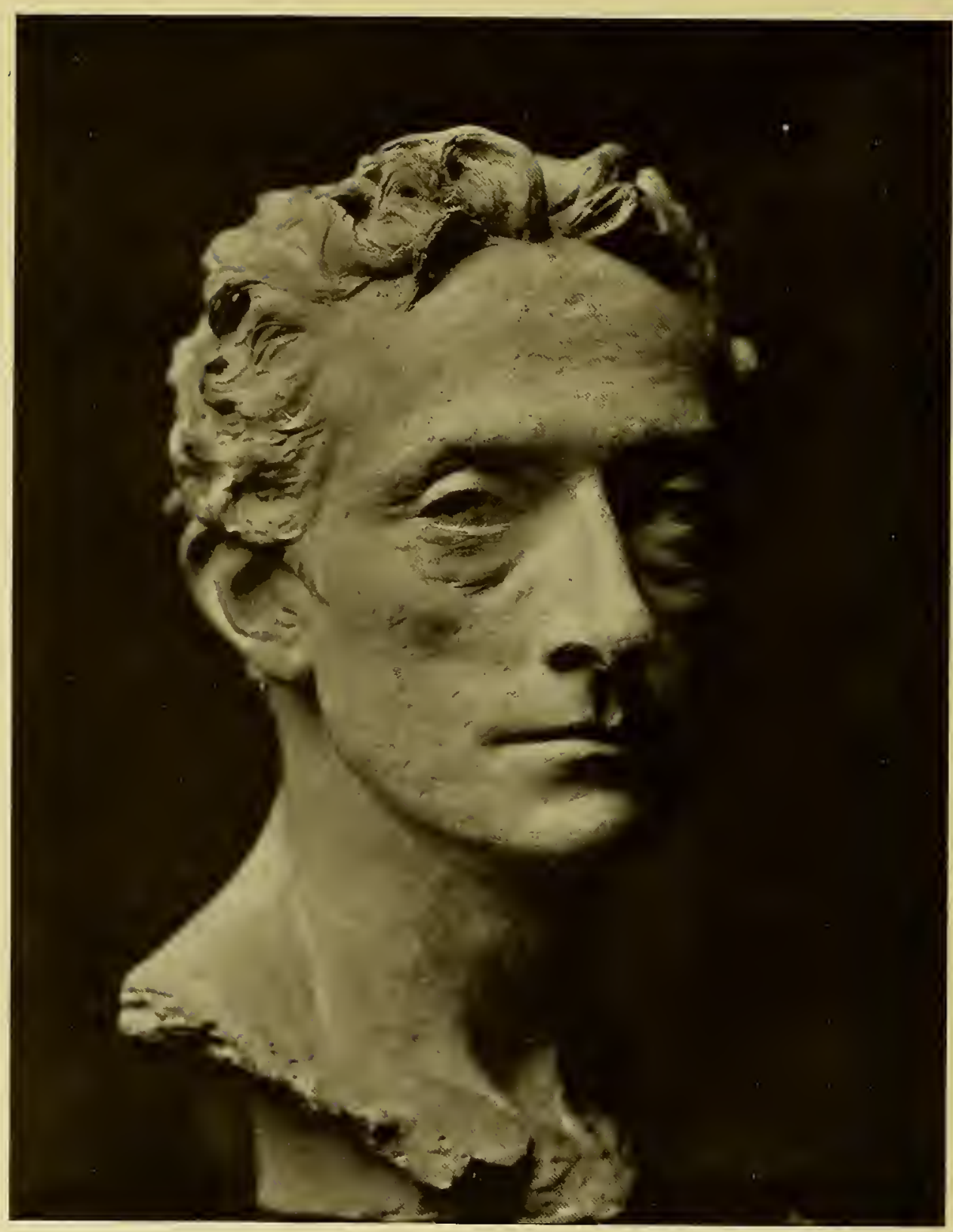

Sir Jobnston Forbes-Robertson

BRON2E 


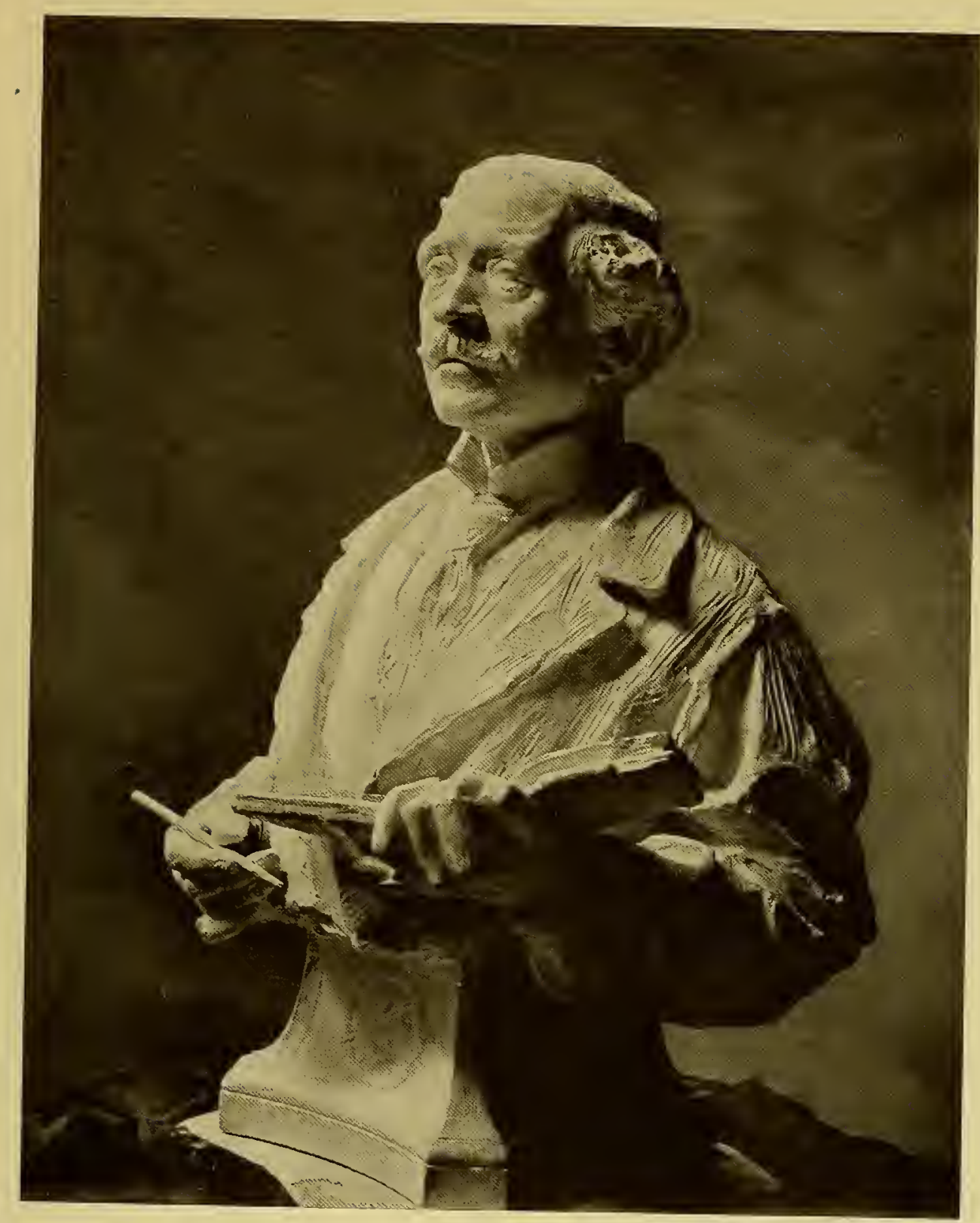

Sir David DMurray

MEMBER OF THE ROYAL ACADEMY OF ARTS - ENGLAND BRONZE 


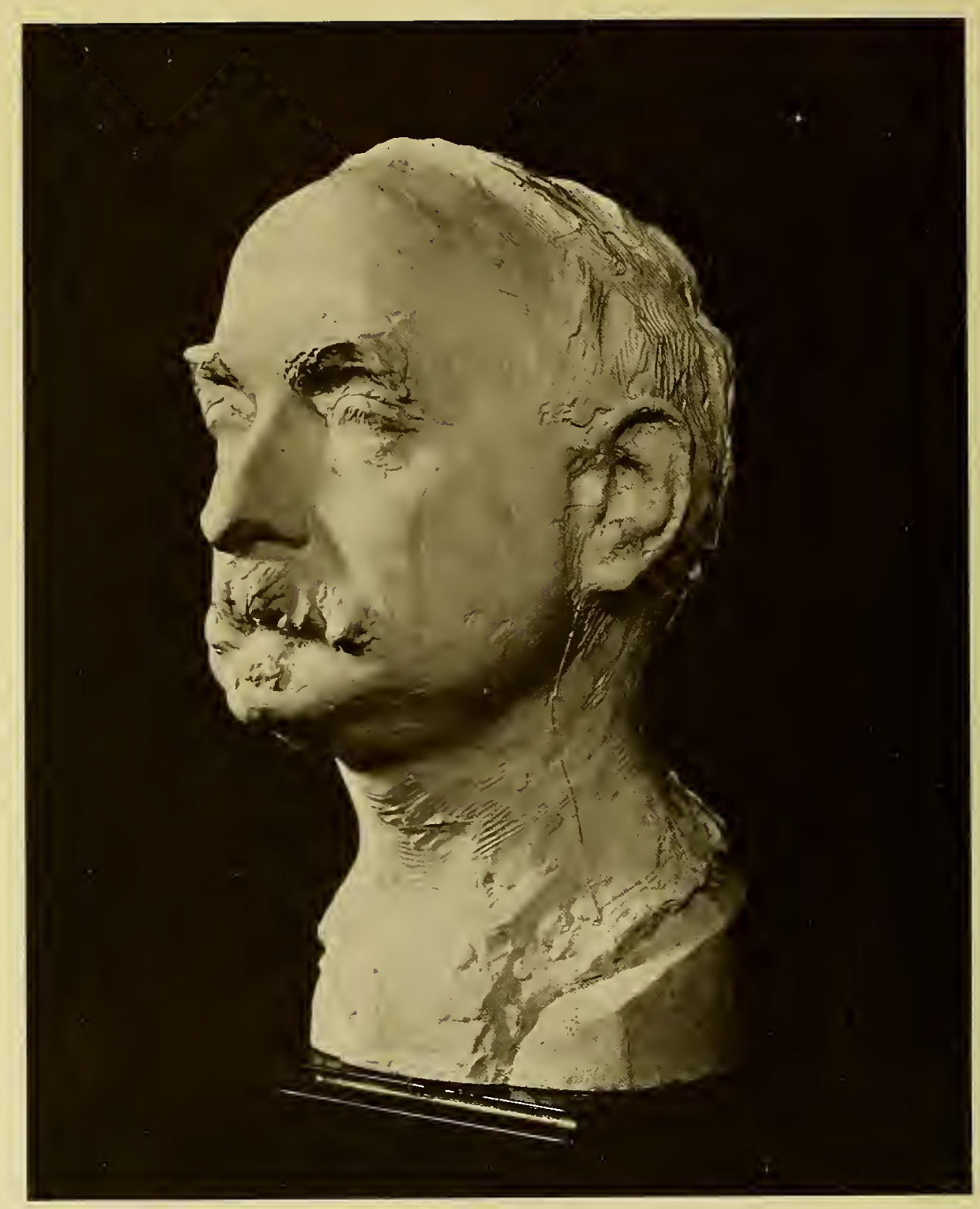

Gari Melchers

BRONZE 


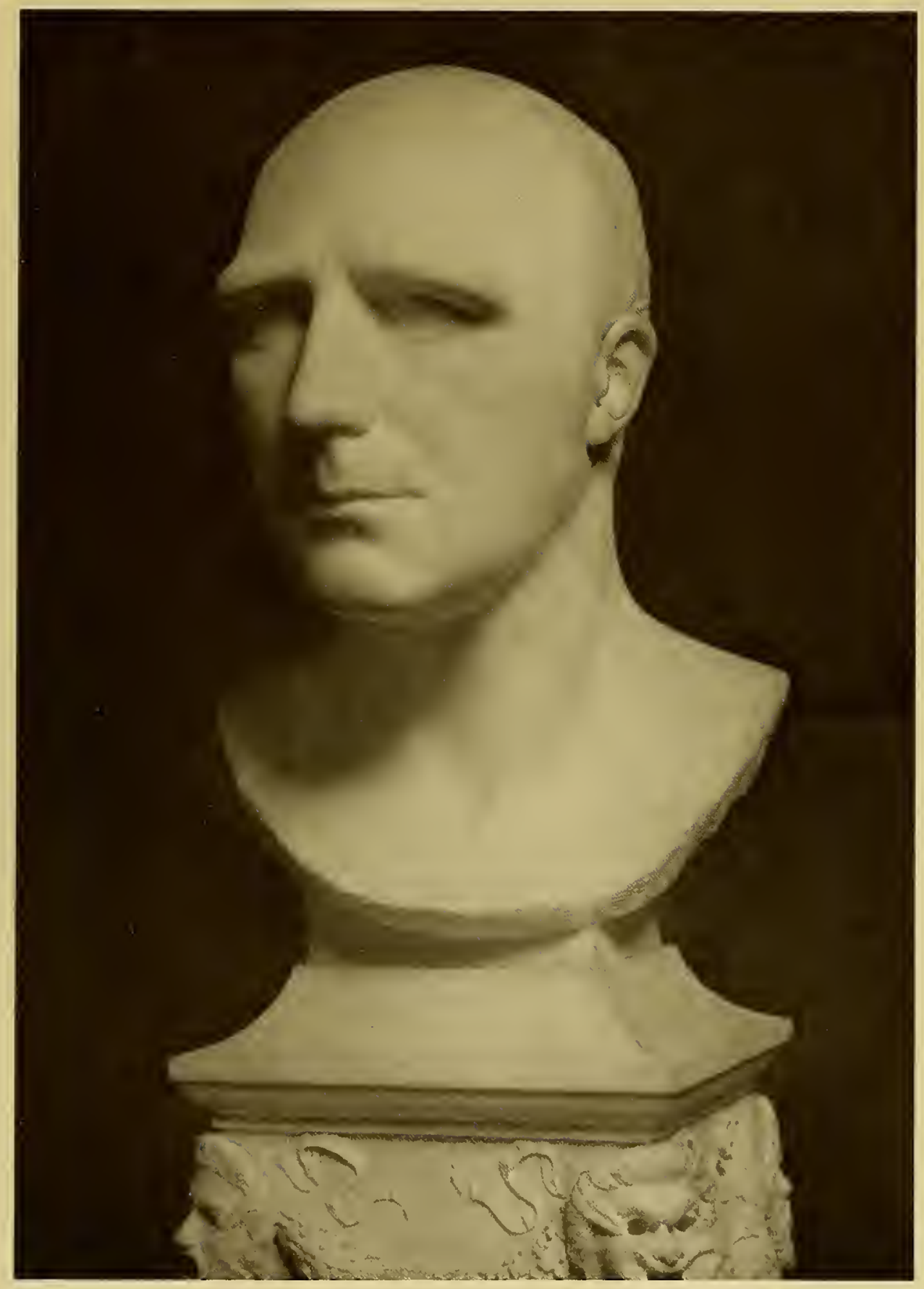

Pinero

MARBLE 


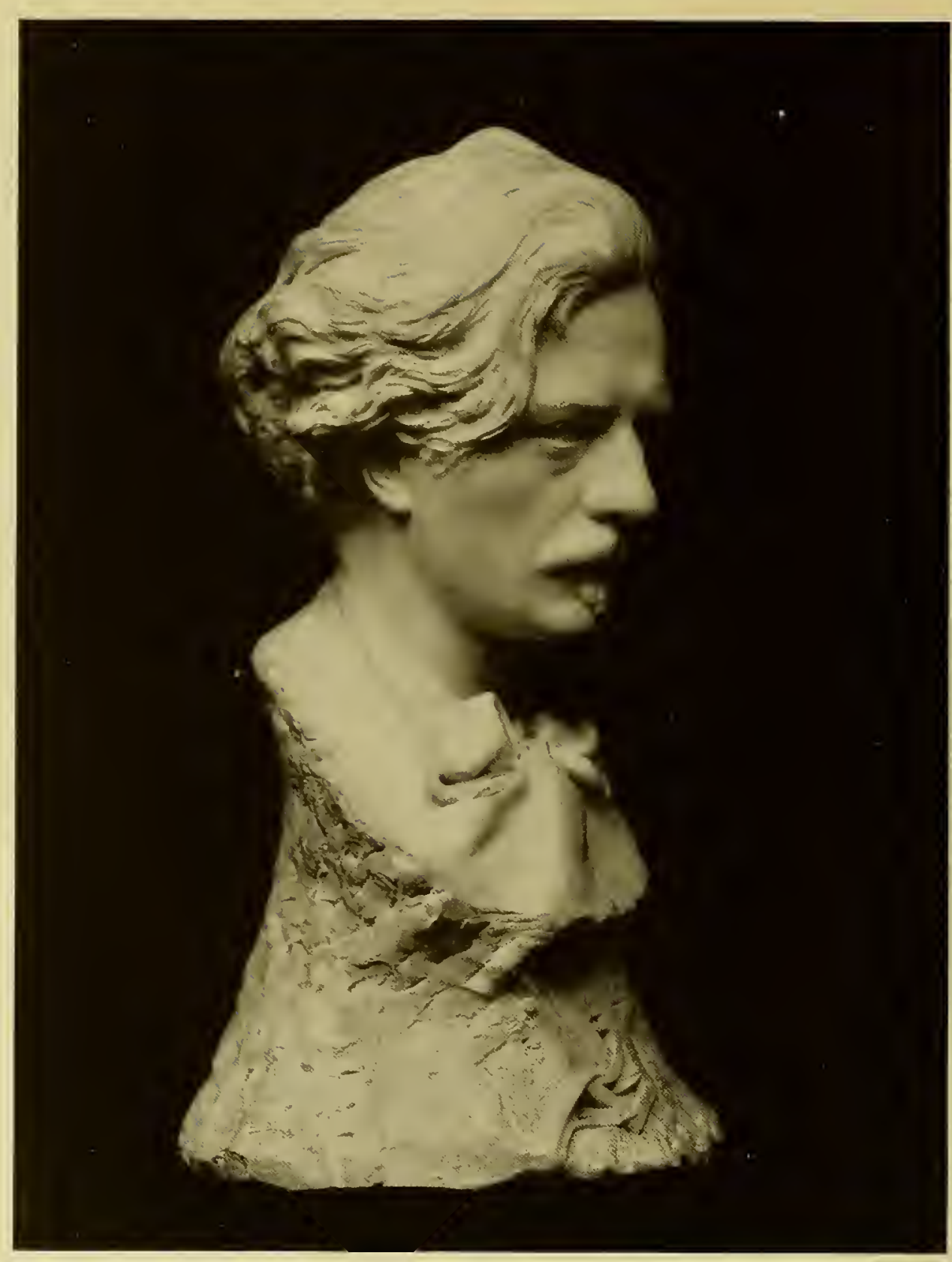

Paderewski

MARBLE 


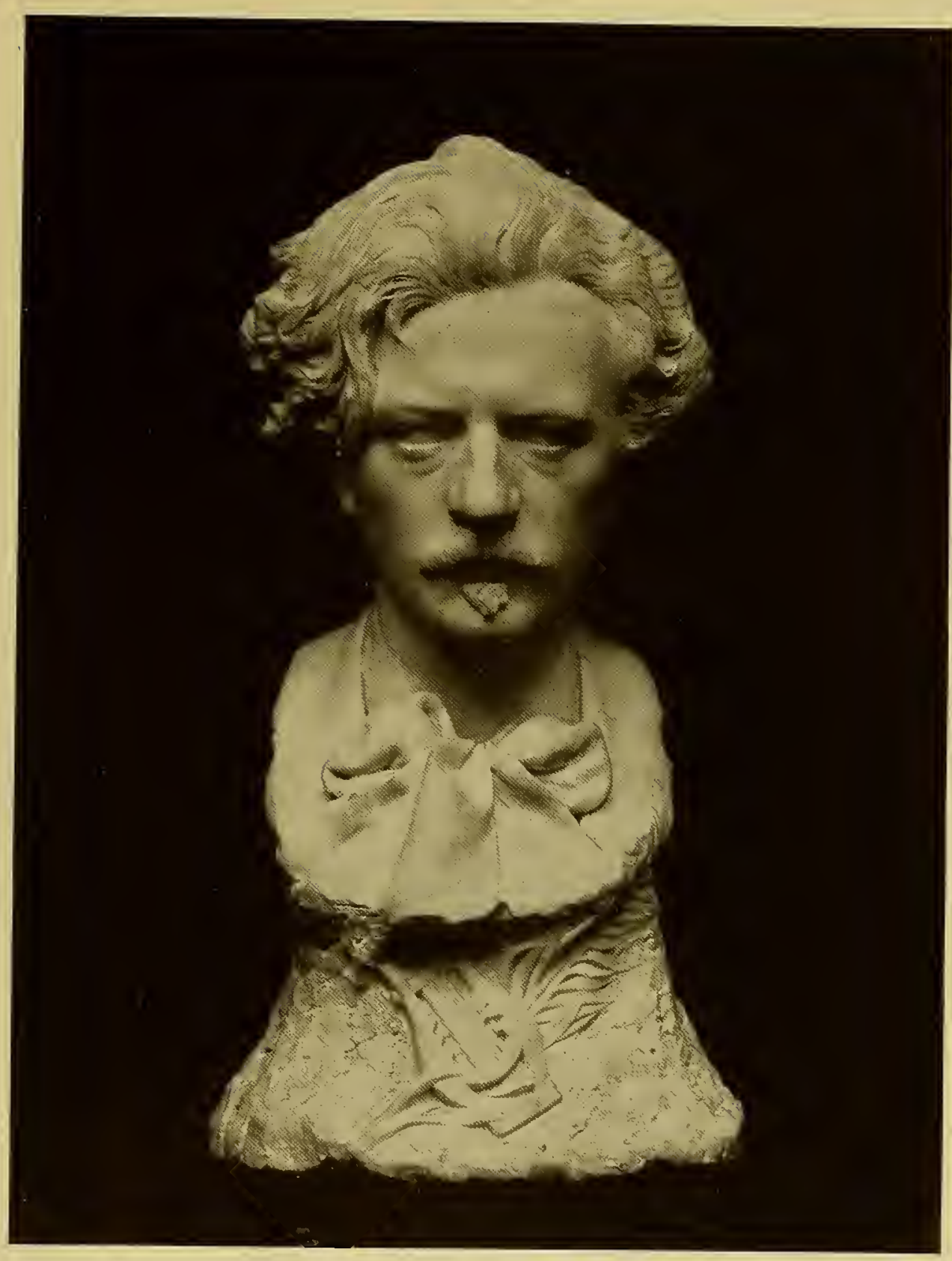

Paderewski

MARBLE 

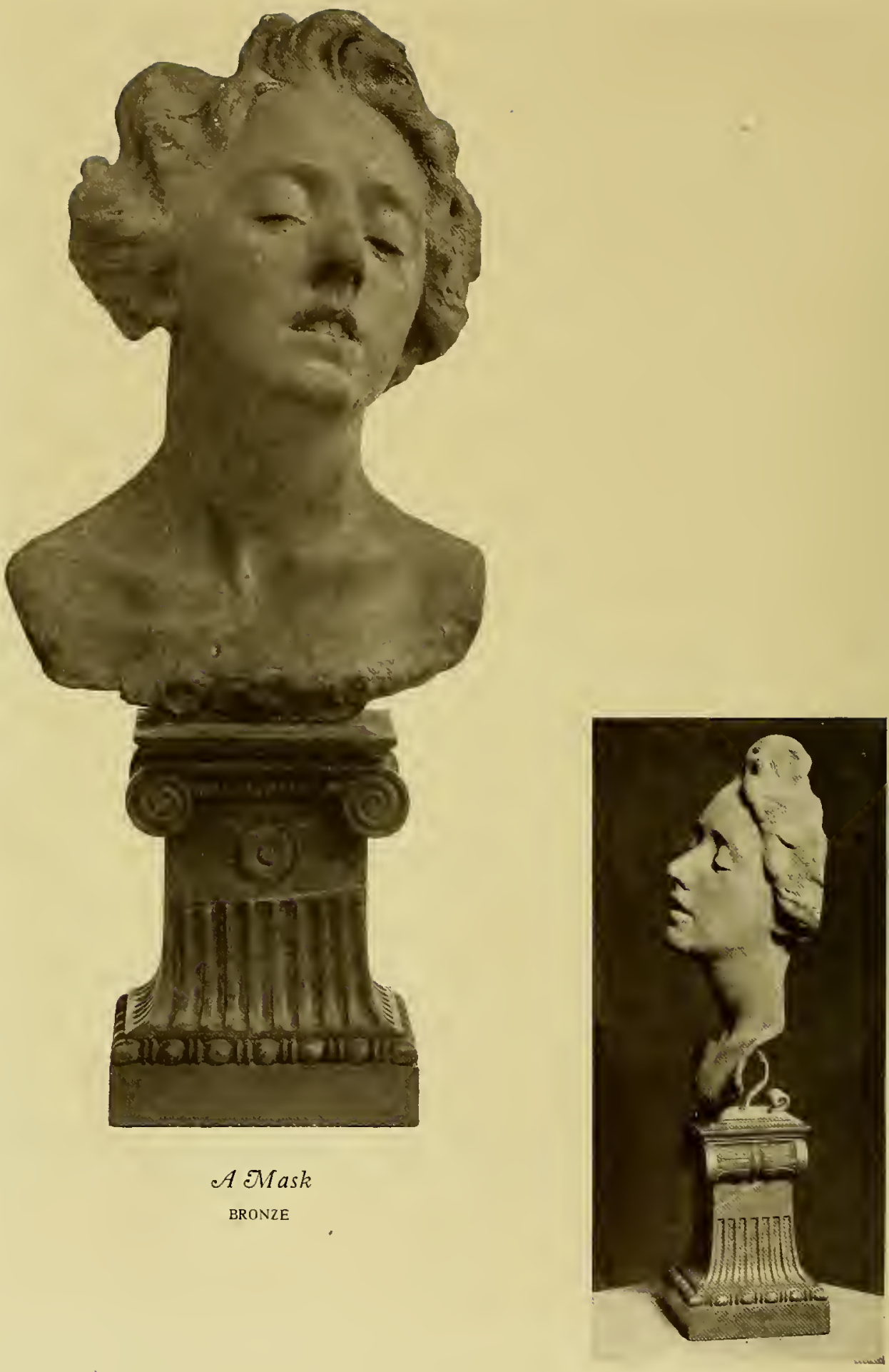


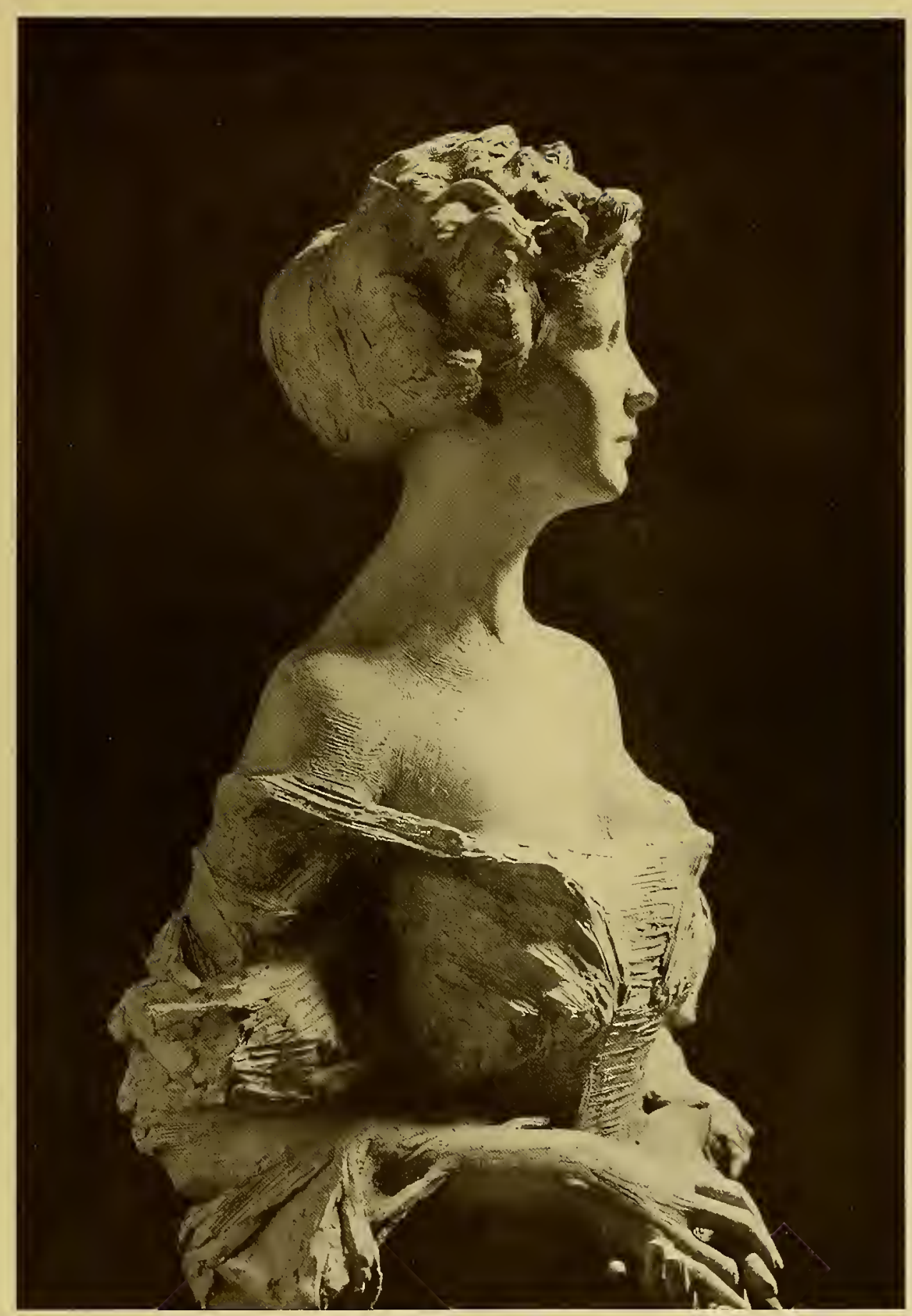

A Portrait Bust 


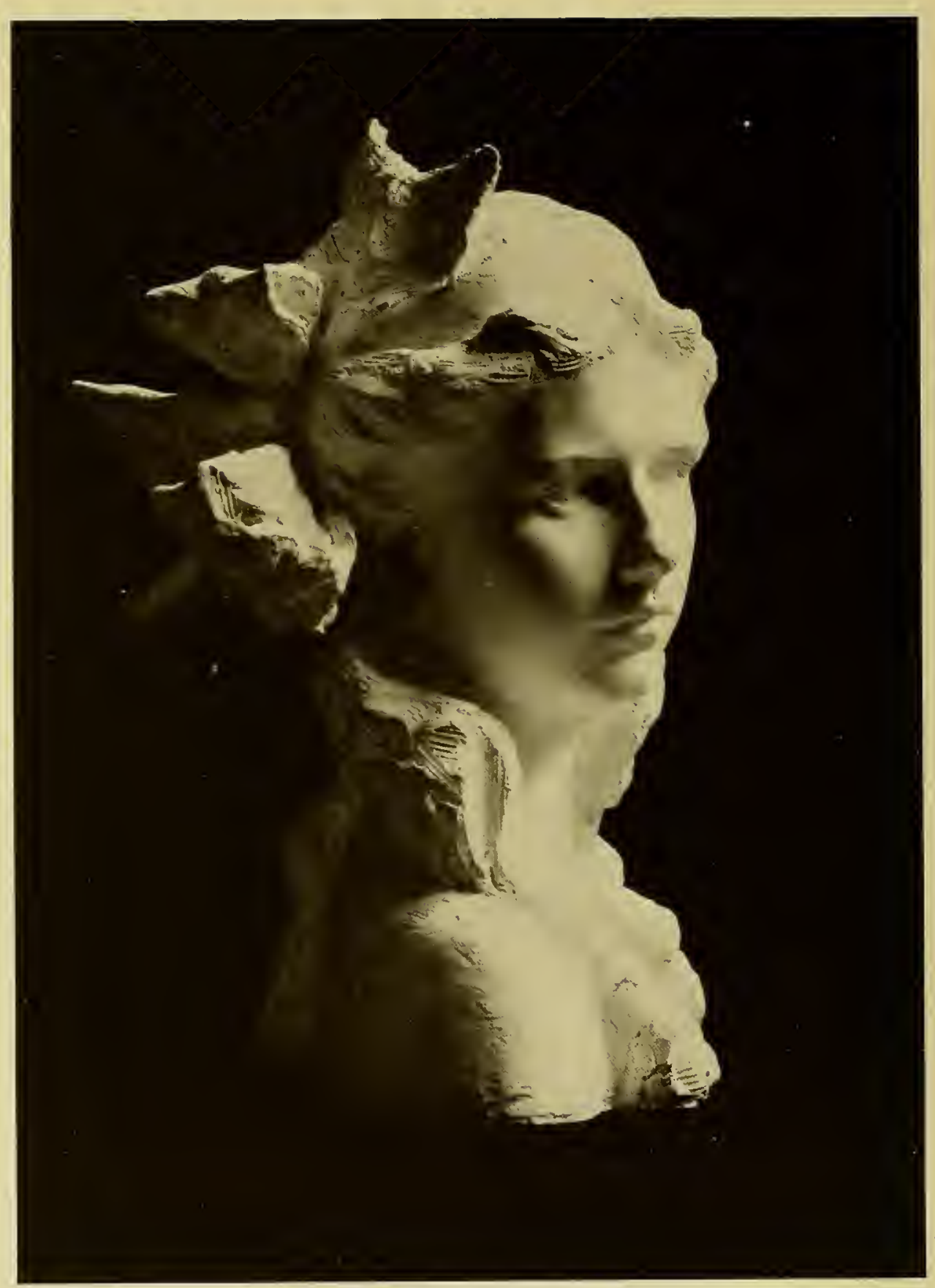

Mabel 


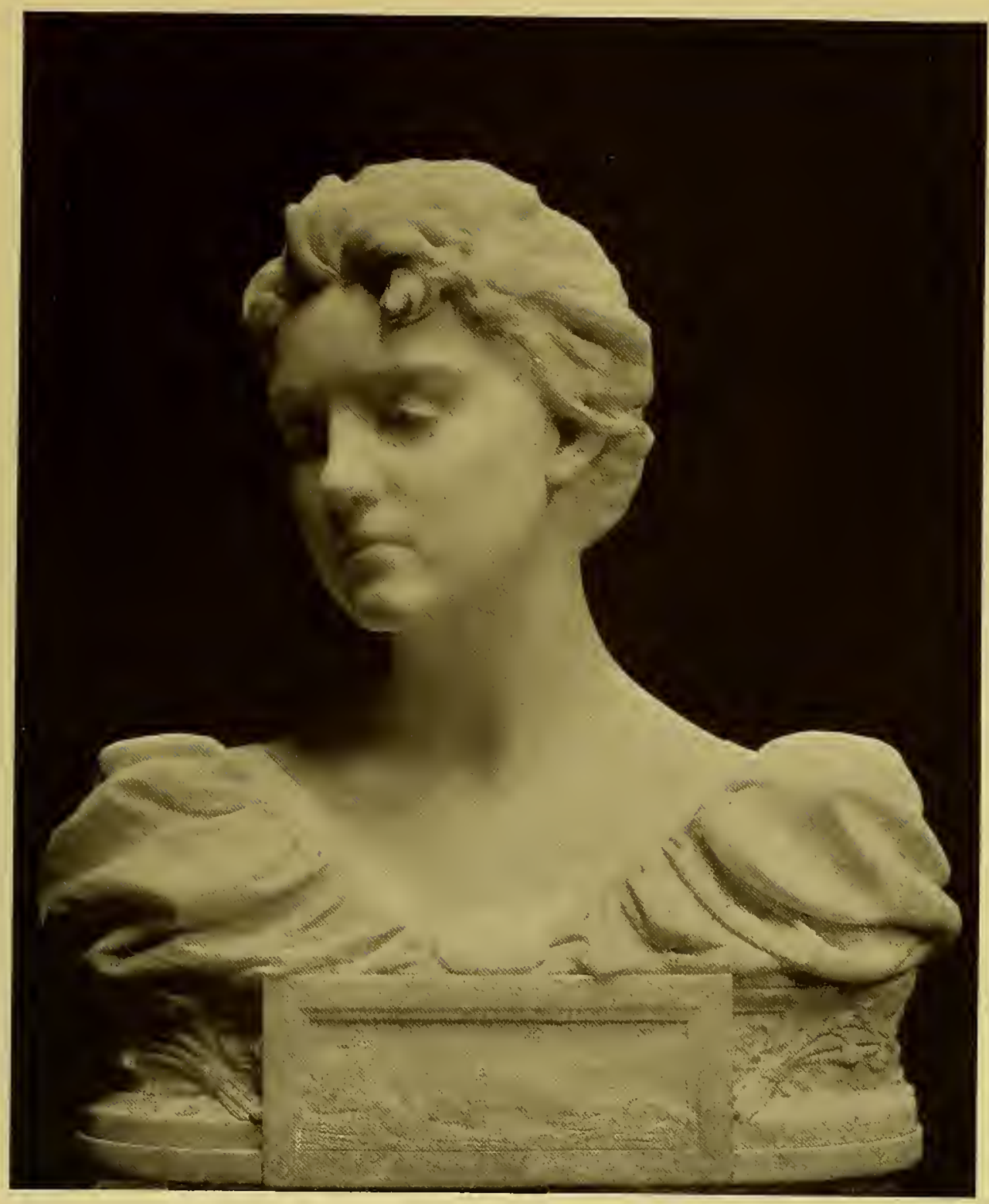

\section{Lady Alice Montague}

The Sister of the Duke of Mancbester, Executed in Marble for the Late Queen Victoria 


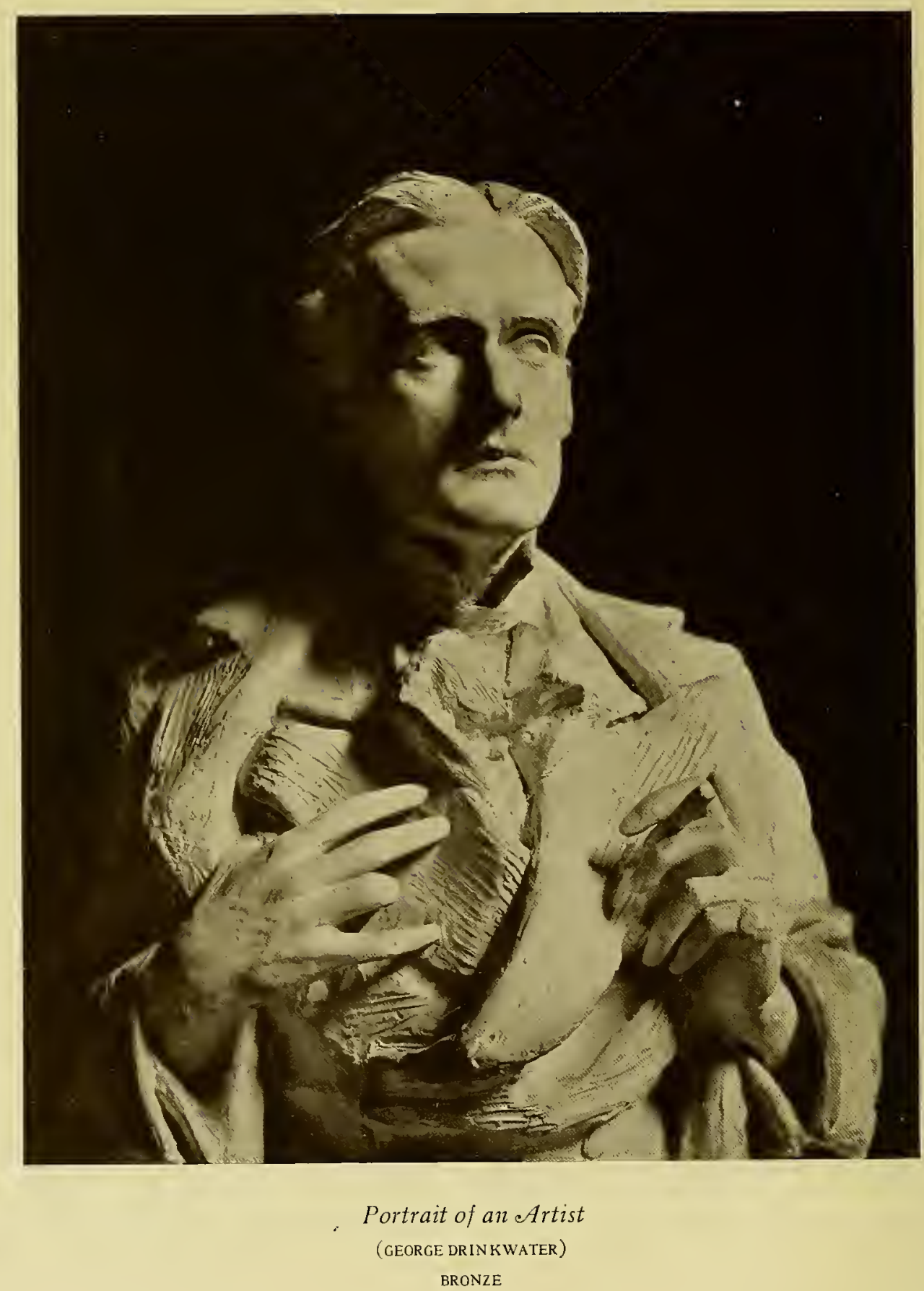




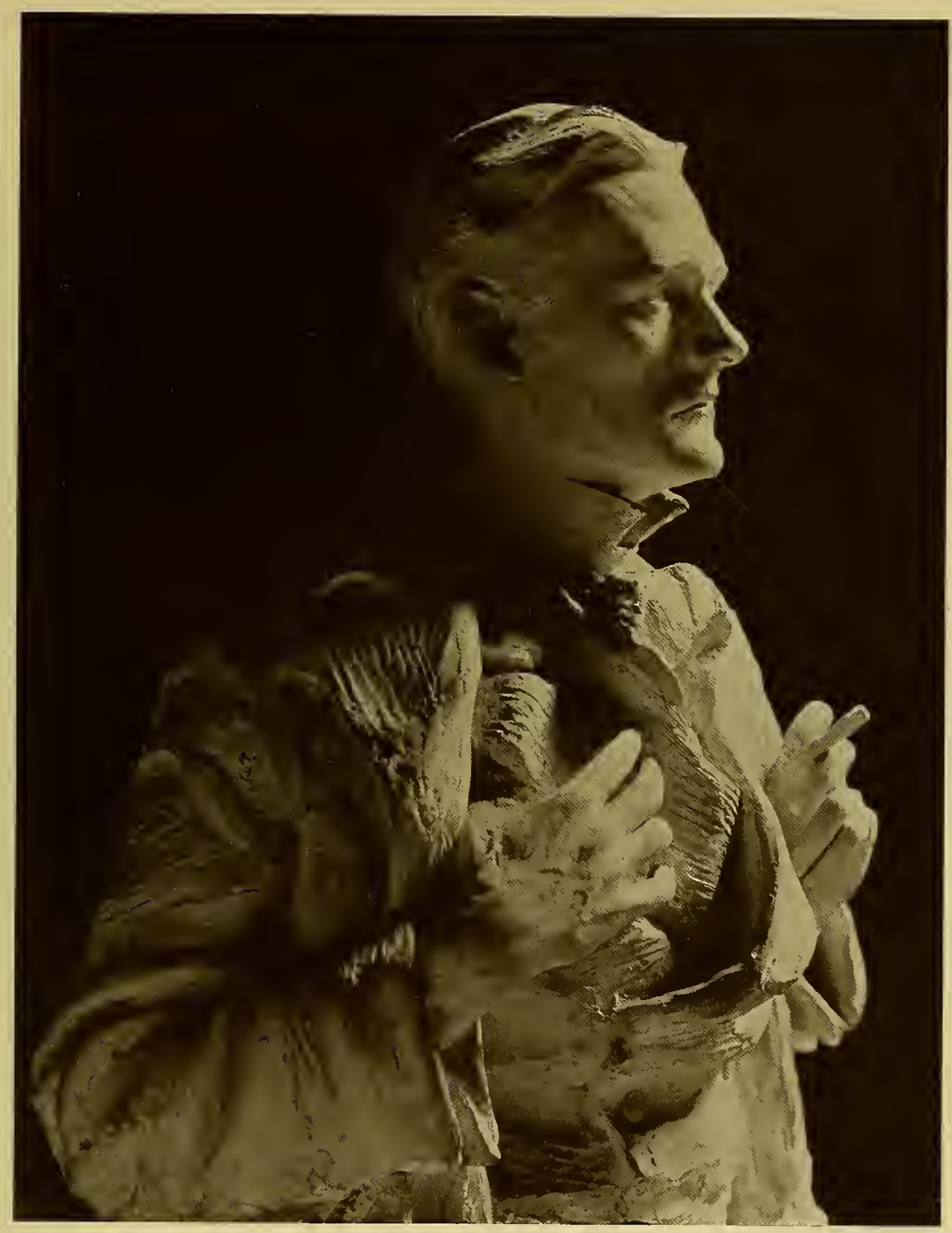

Portrait of an Artist

(GEORGE DRINKWATER)

BRONZE 


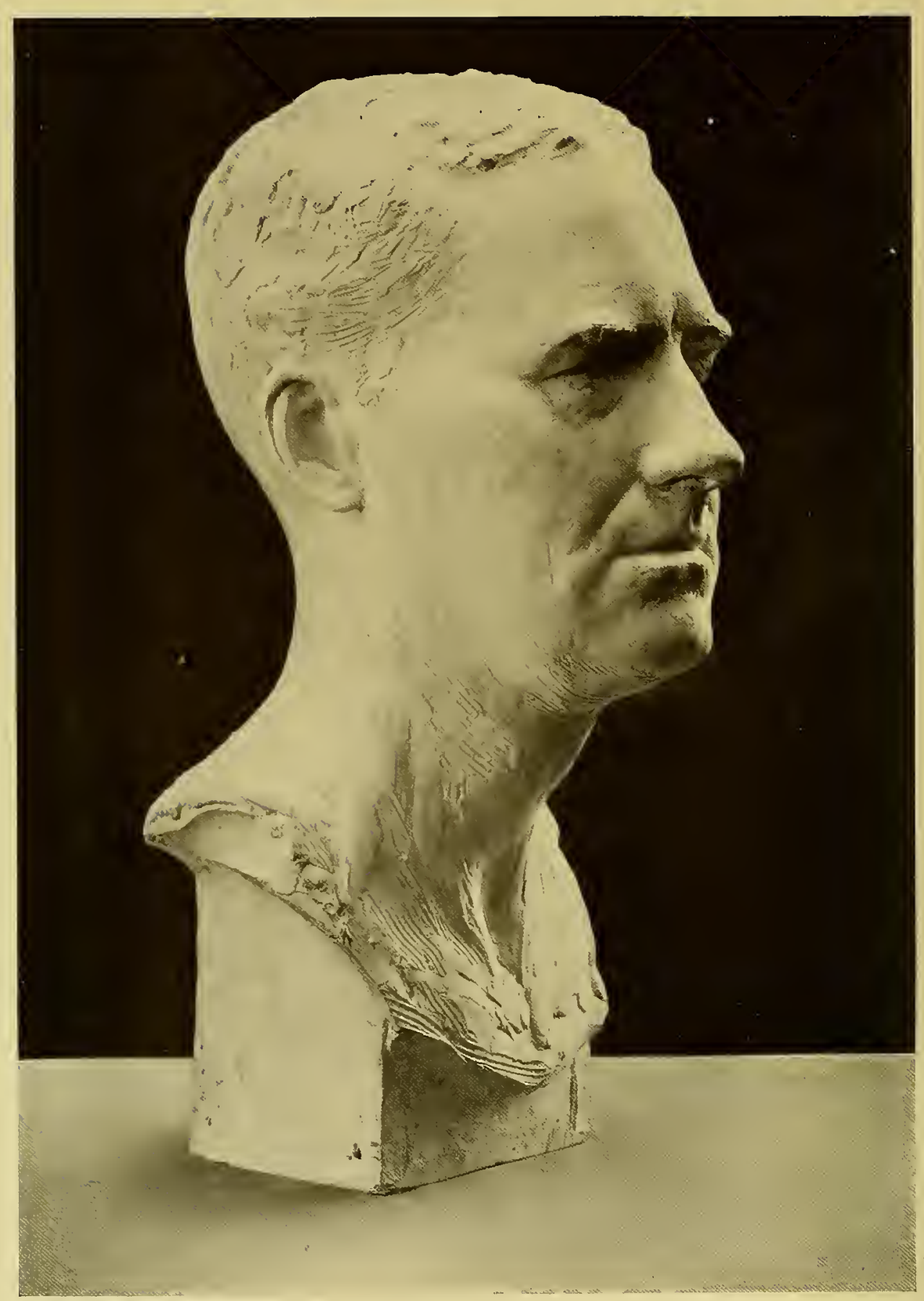

Portrait of Liston L. Lewis

BRONZE 


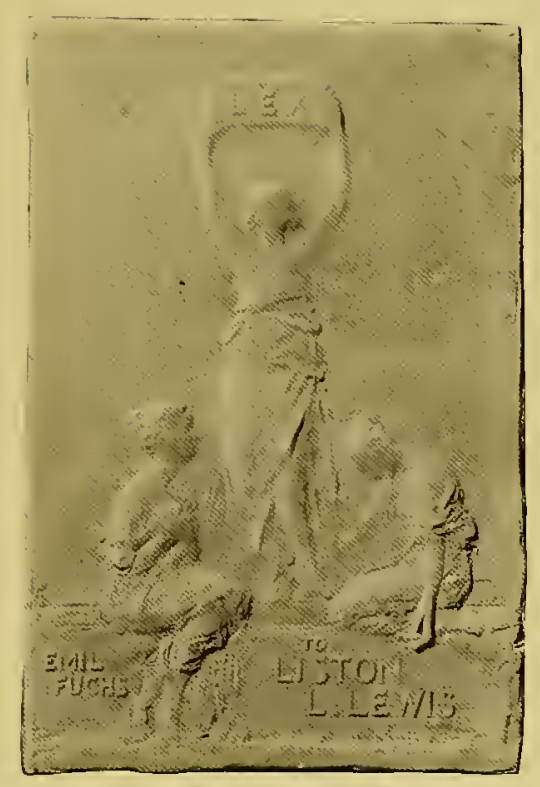

Plaquette in the Pedestal for the Lewis Portrait

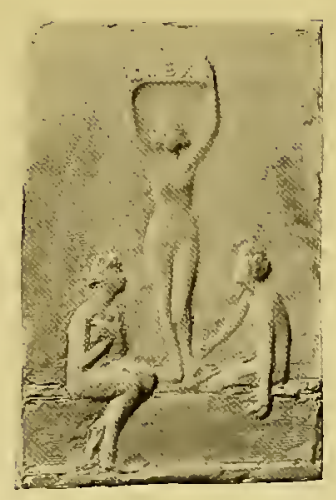



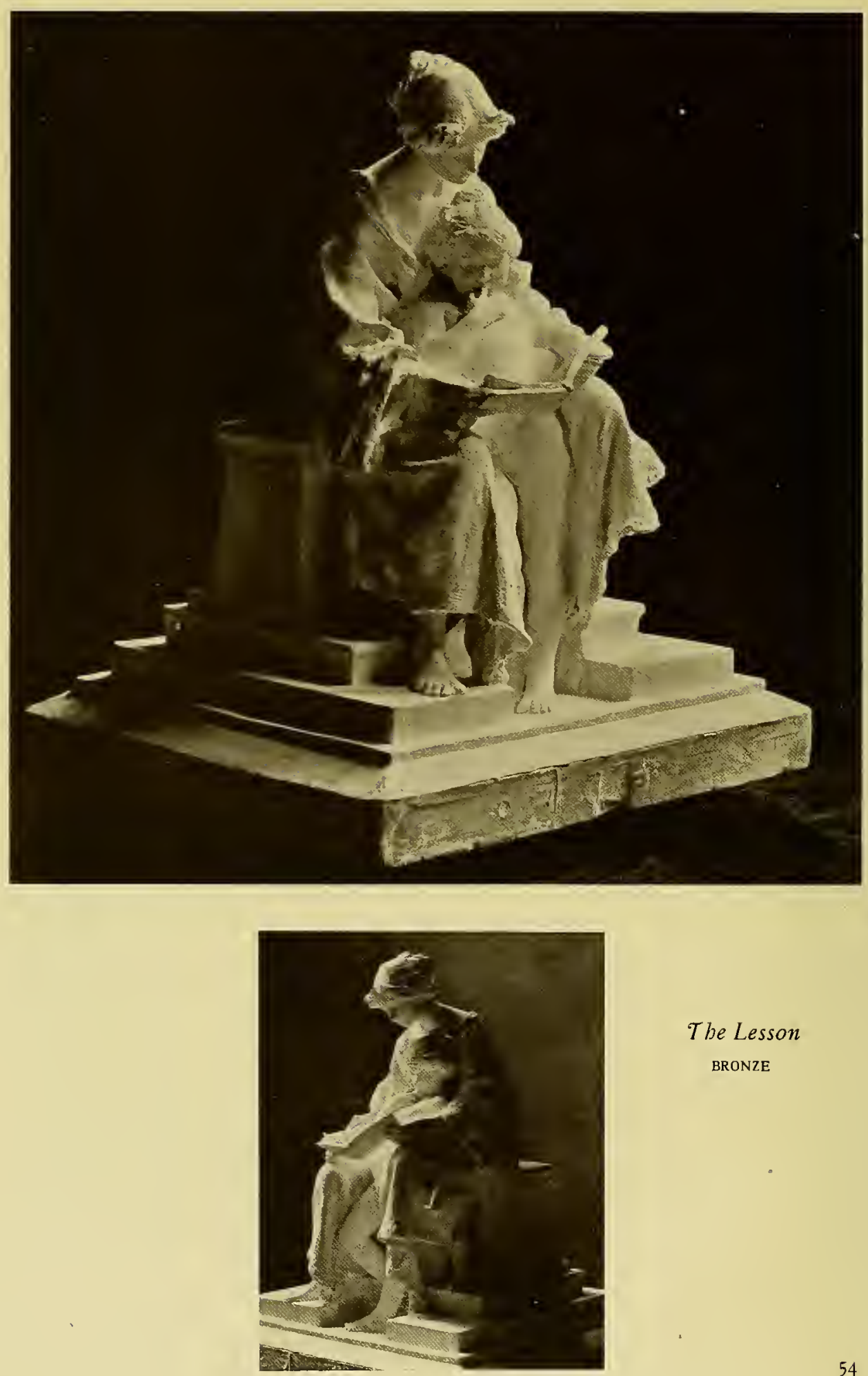

The Lesson

BRONZE 


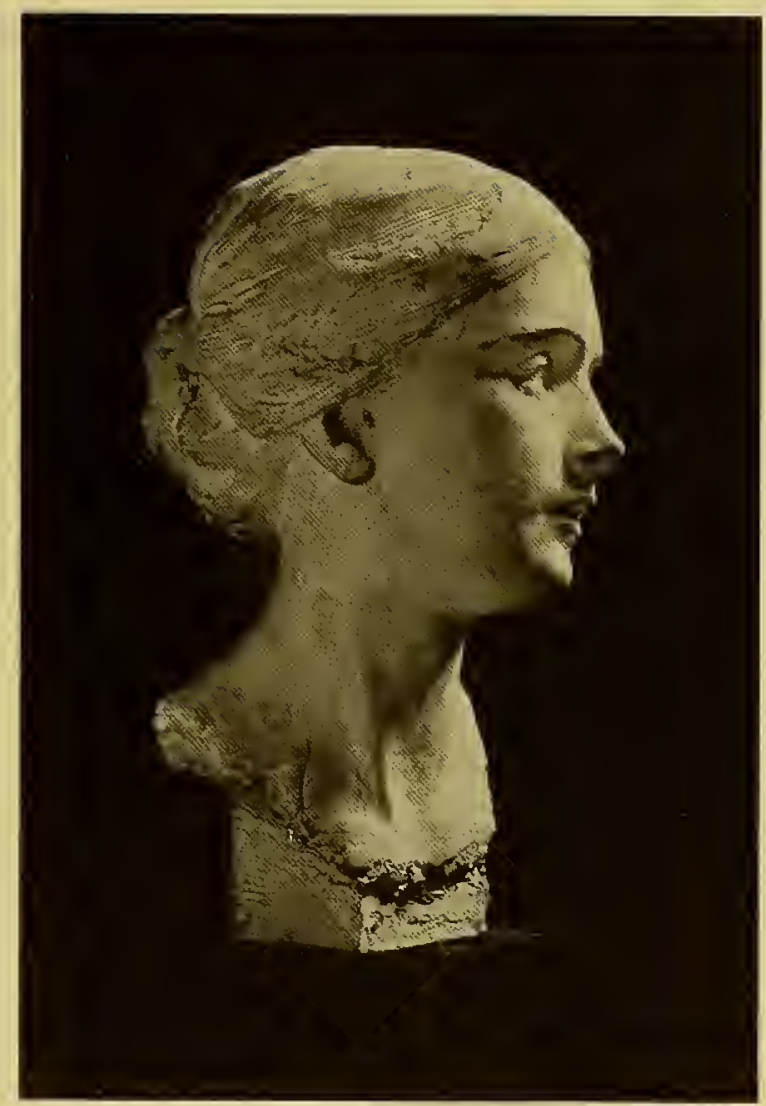

Girlbood

(PHYLLIS)

MARBLE 


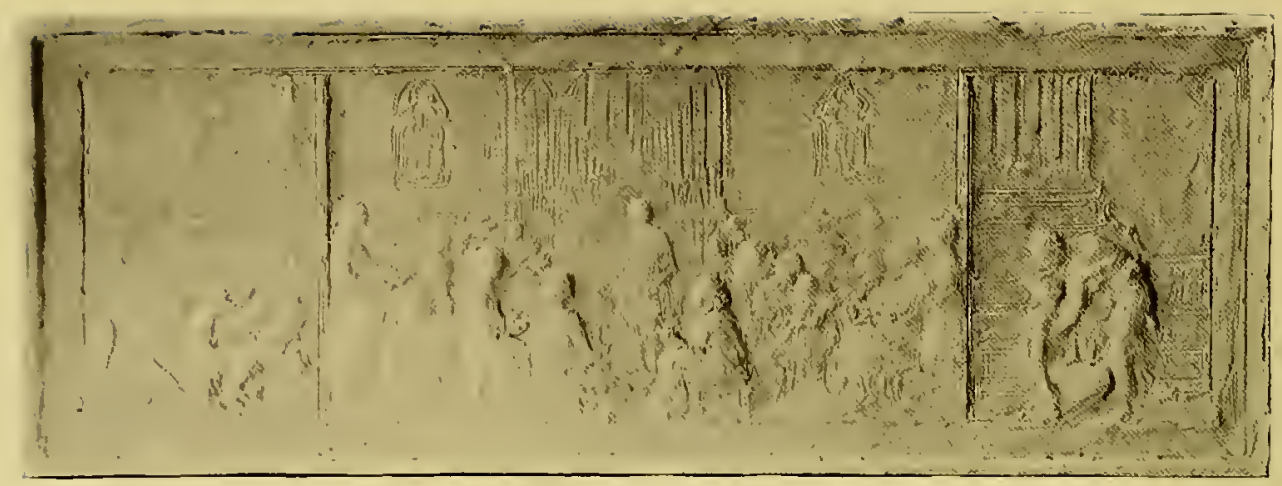

Devotion

Work for the Sunday School

Cbarity

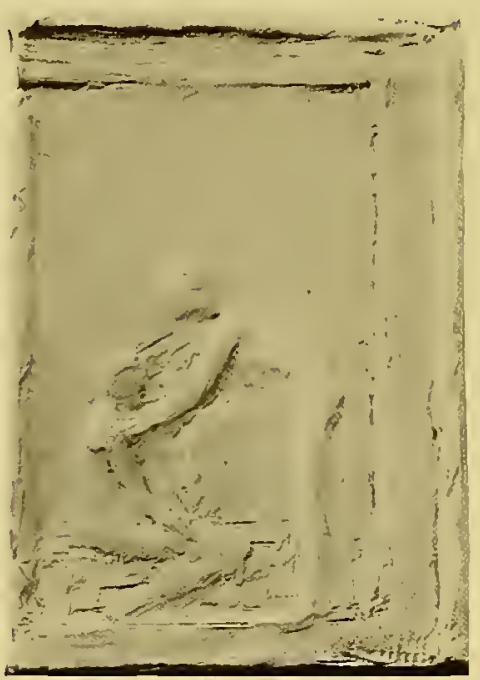

Sketches for the Bas Relief in the H. J. Heinz CMemorial PITTSBURGH 


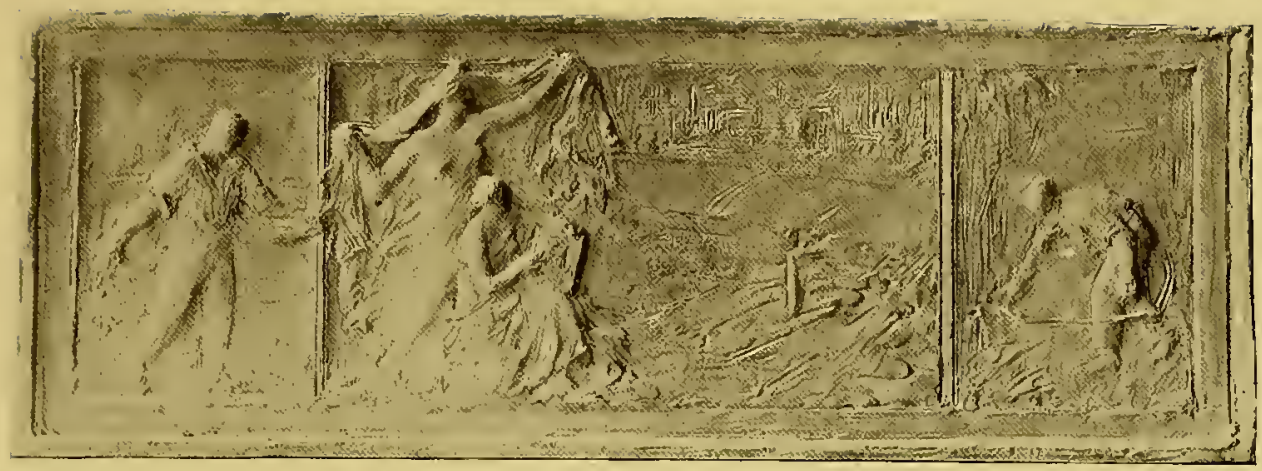

The Sower

The Jrower

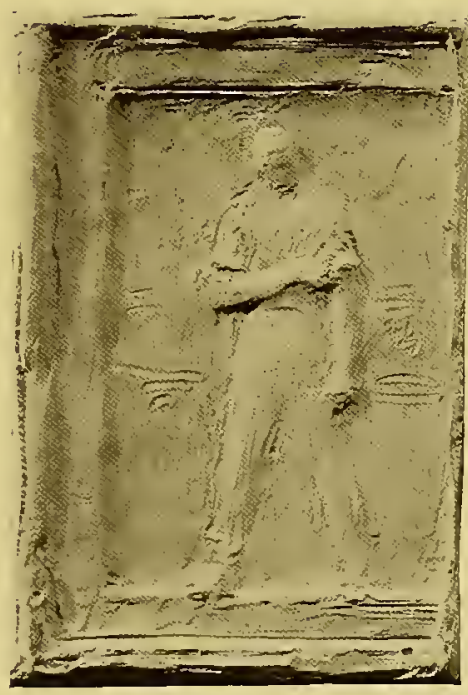

Sketches for the Bas Relief in the H.J. Heinz Memorial PITTSBURGH 


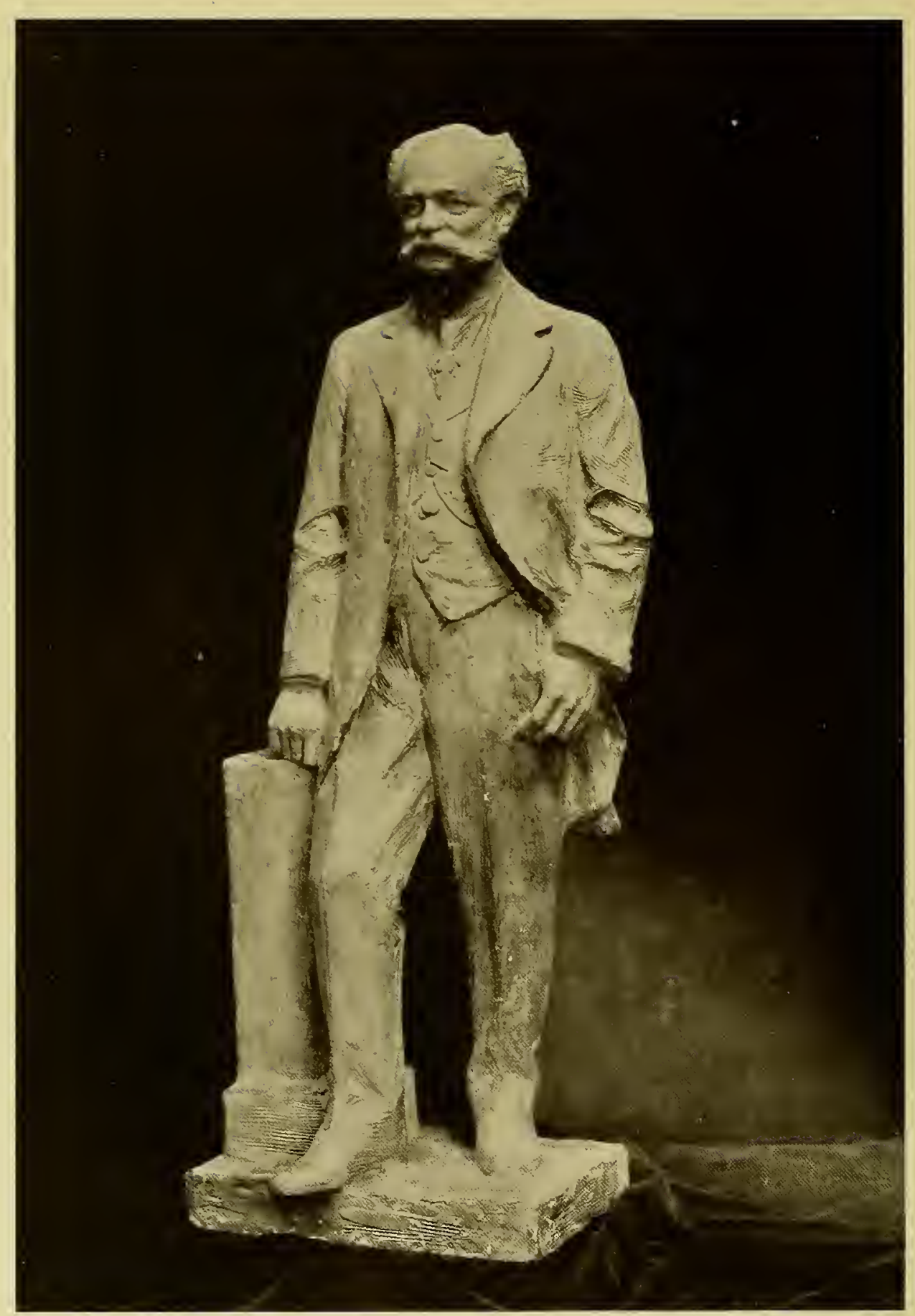

Henry J.Heinz

OModel for the Portrait Statue to be executed in bronze in Pittsburgh, given by the Employees to commemorate the Fiftieth anniversary of the founding of H.J. Heini Company 


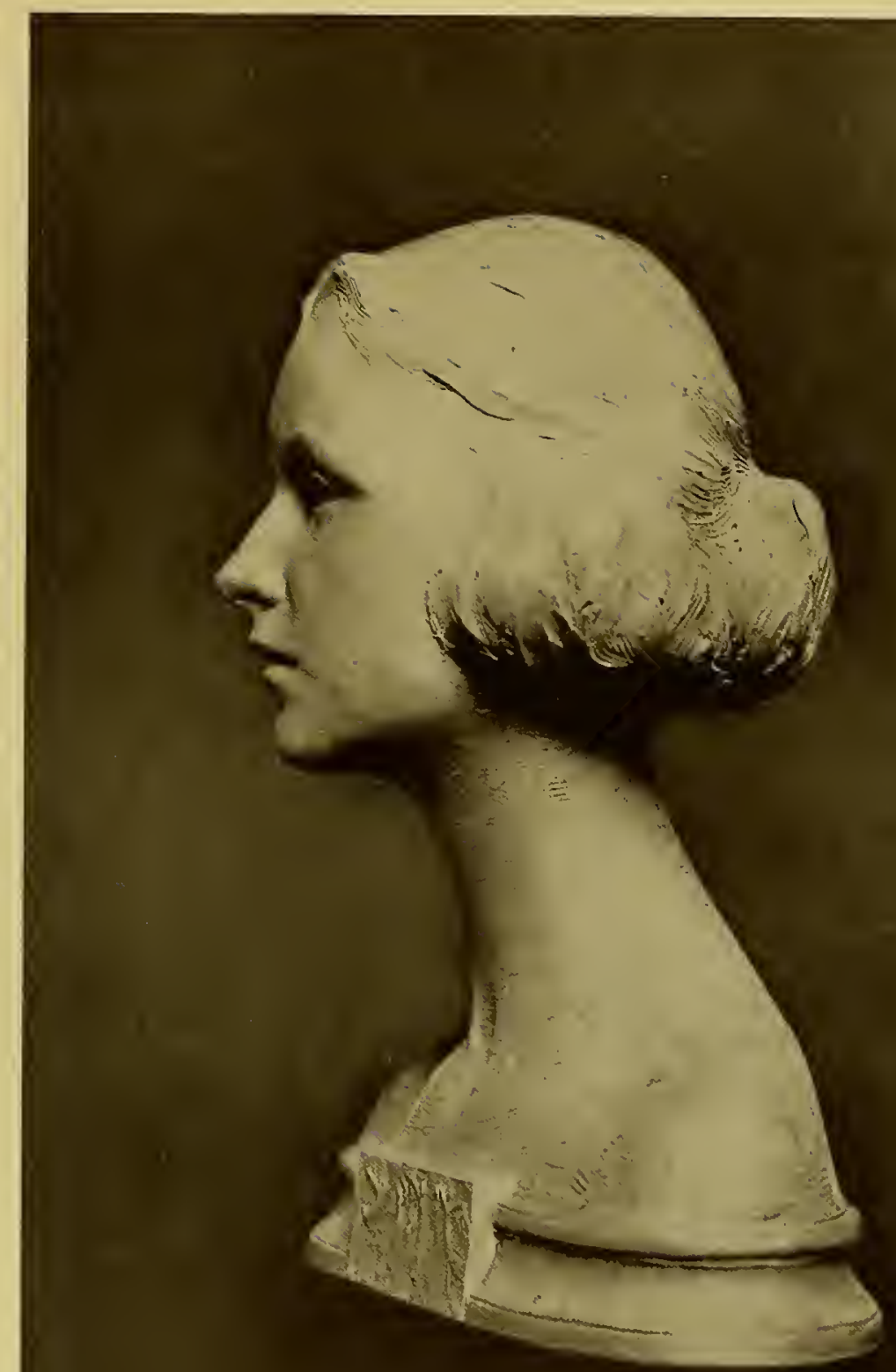

\section{Sylvana}

GESSO 


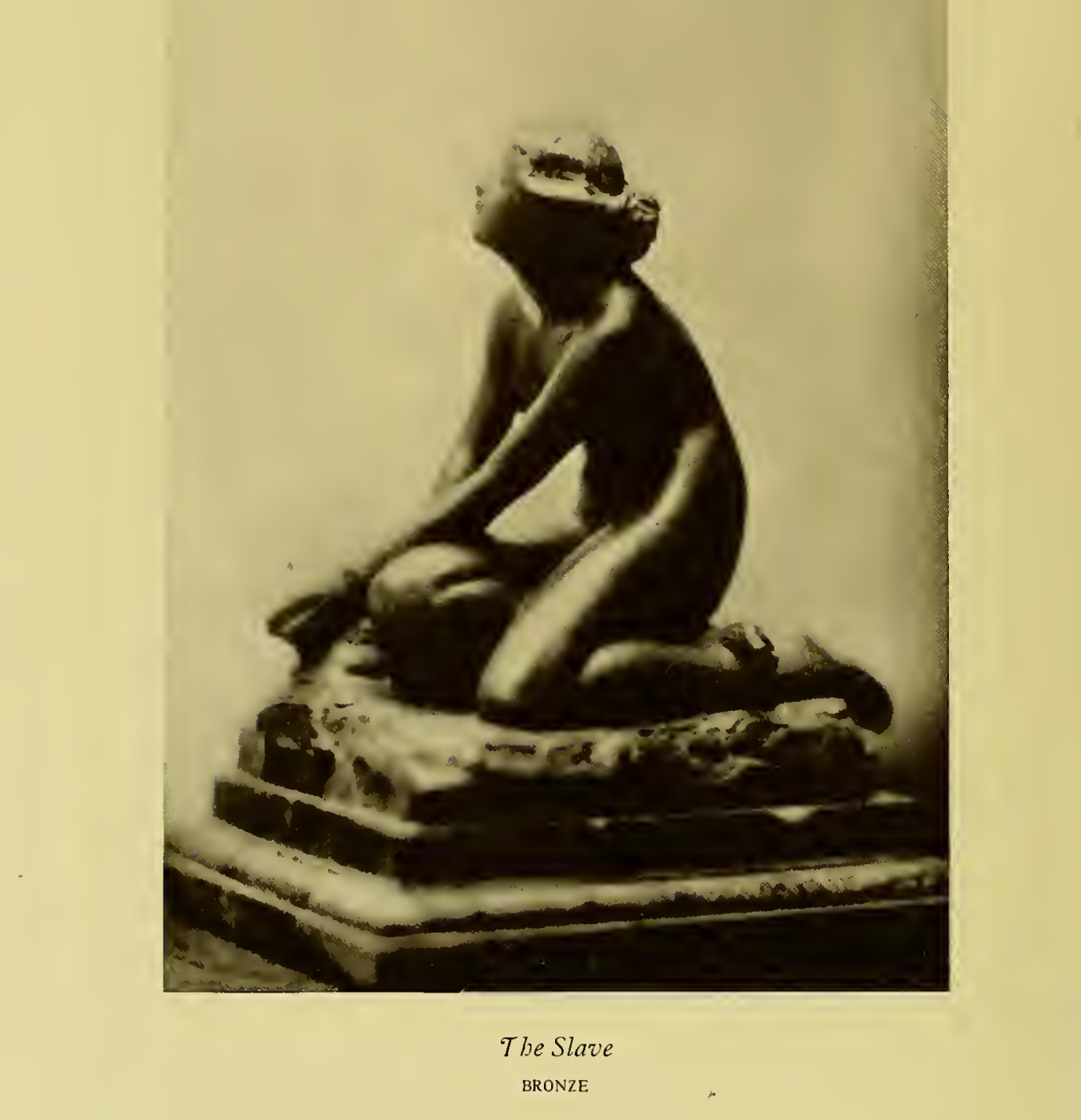


PAINTINGS 



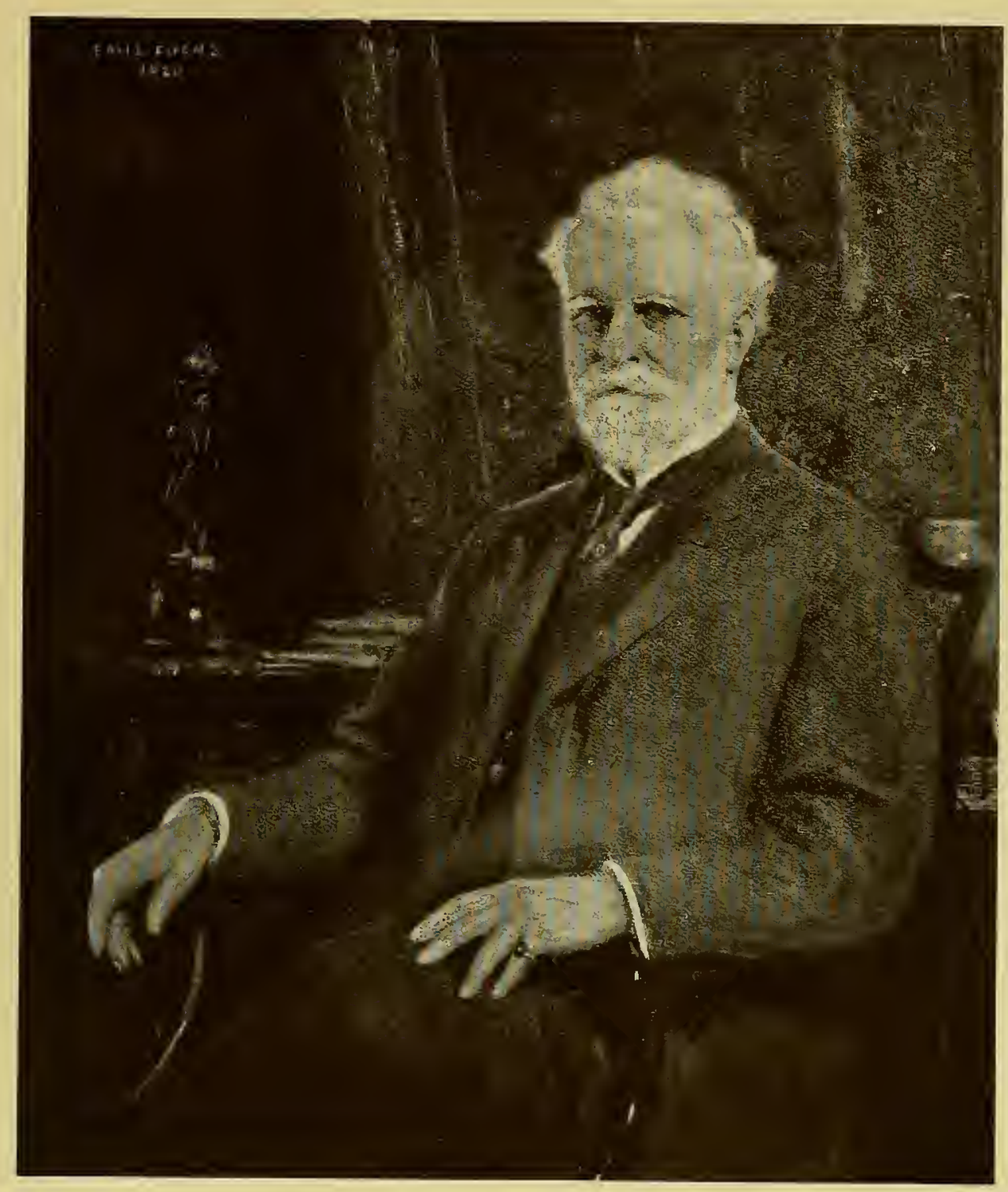

Ambrose Swasey 


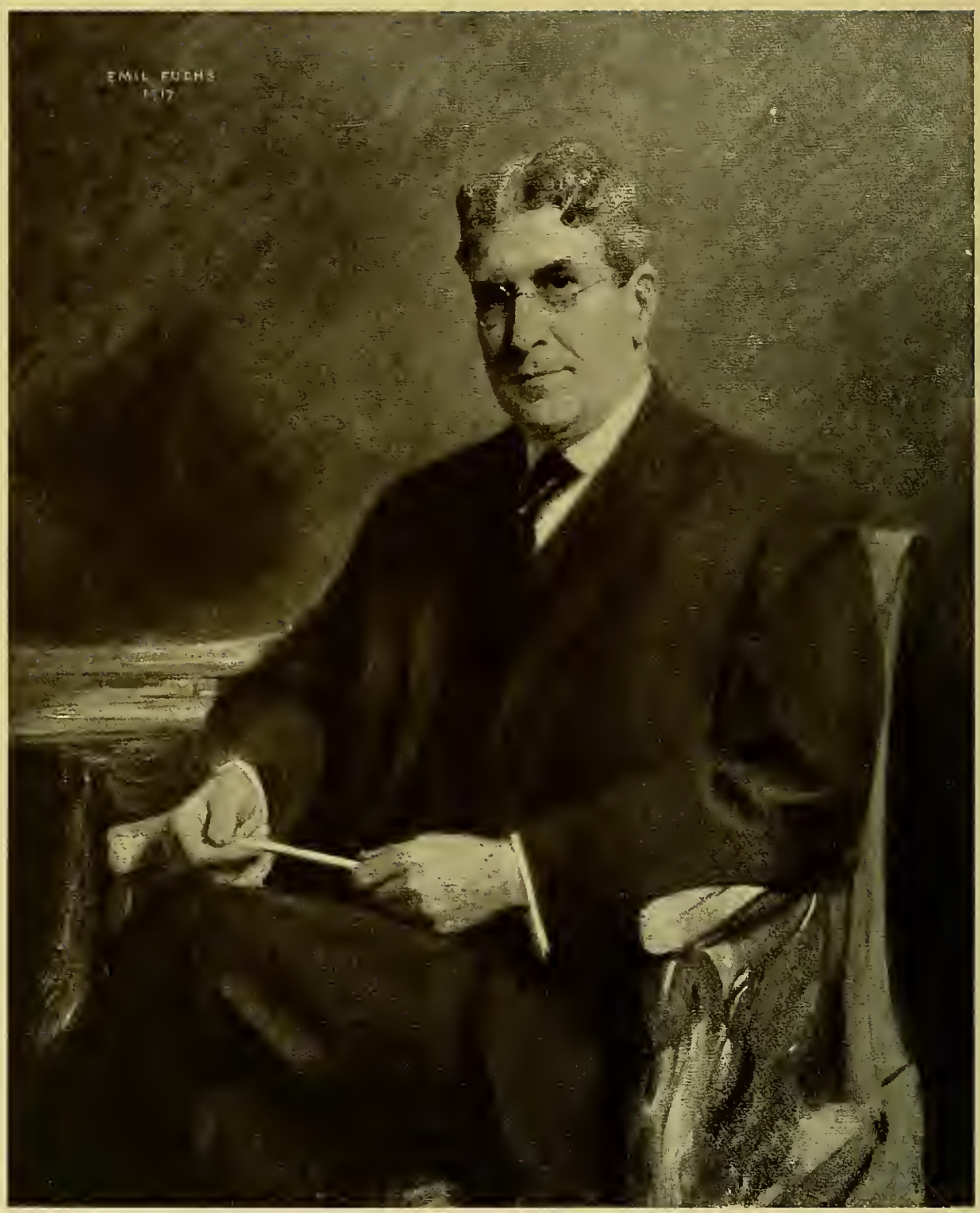

Lindley M. Garrison

PAINTED FOR THE WAR DEPARTMENT

WASHINGTON 


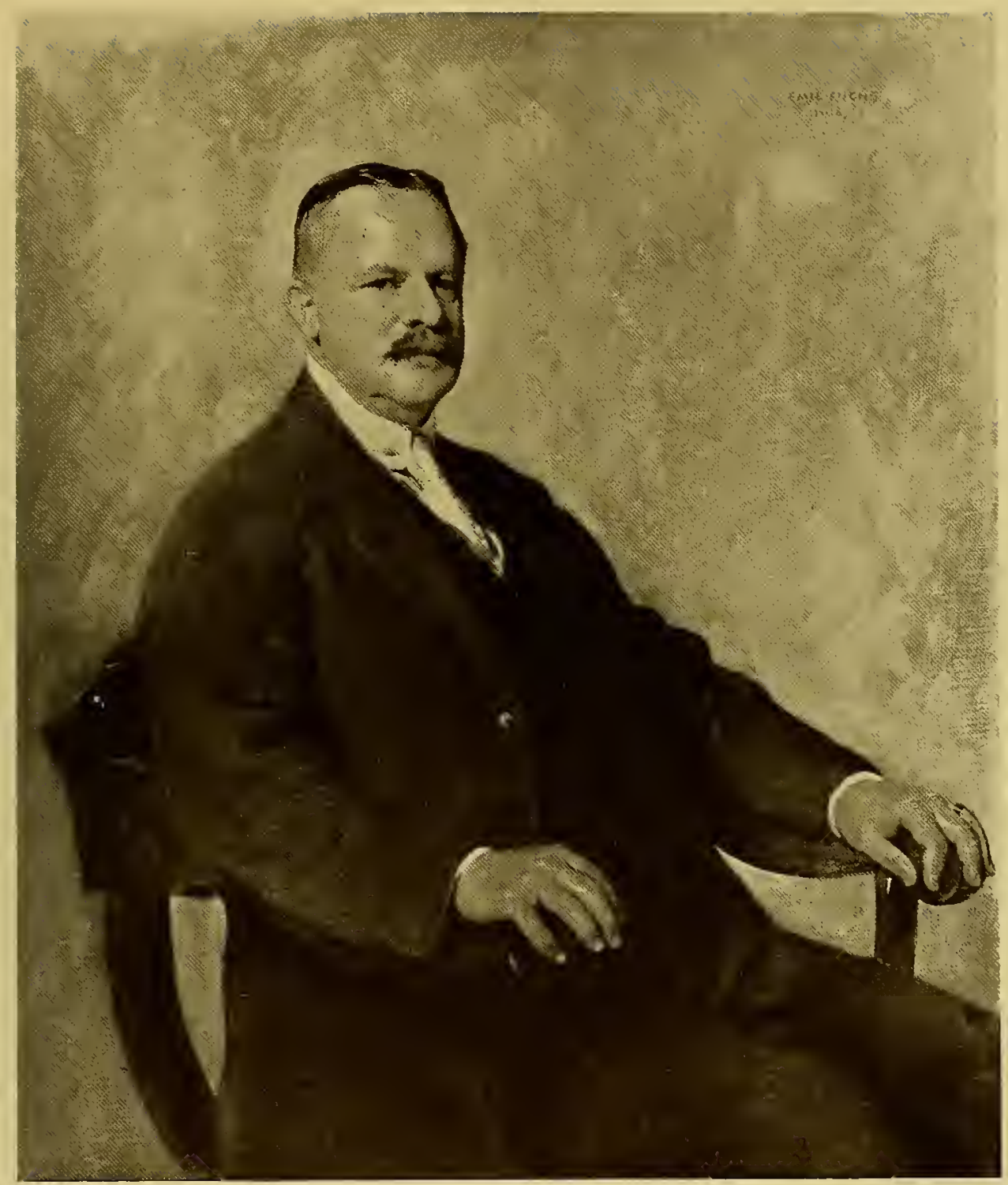

George J. Gould 


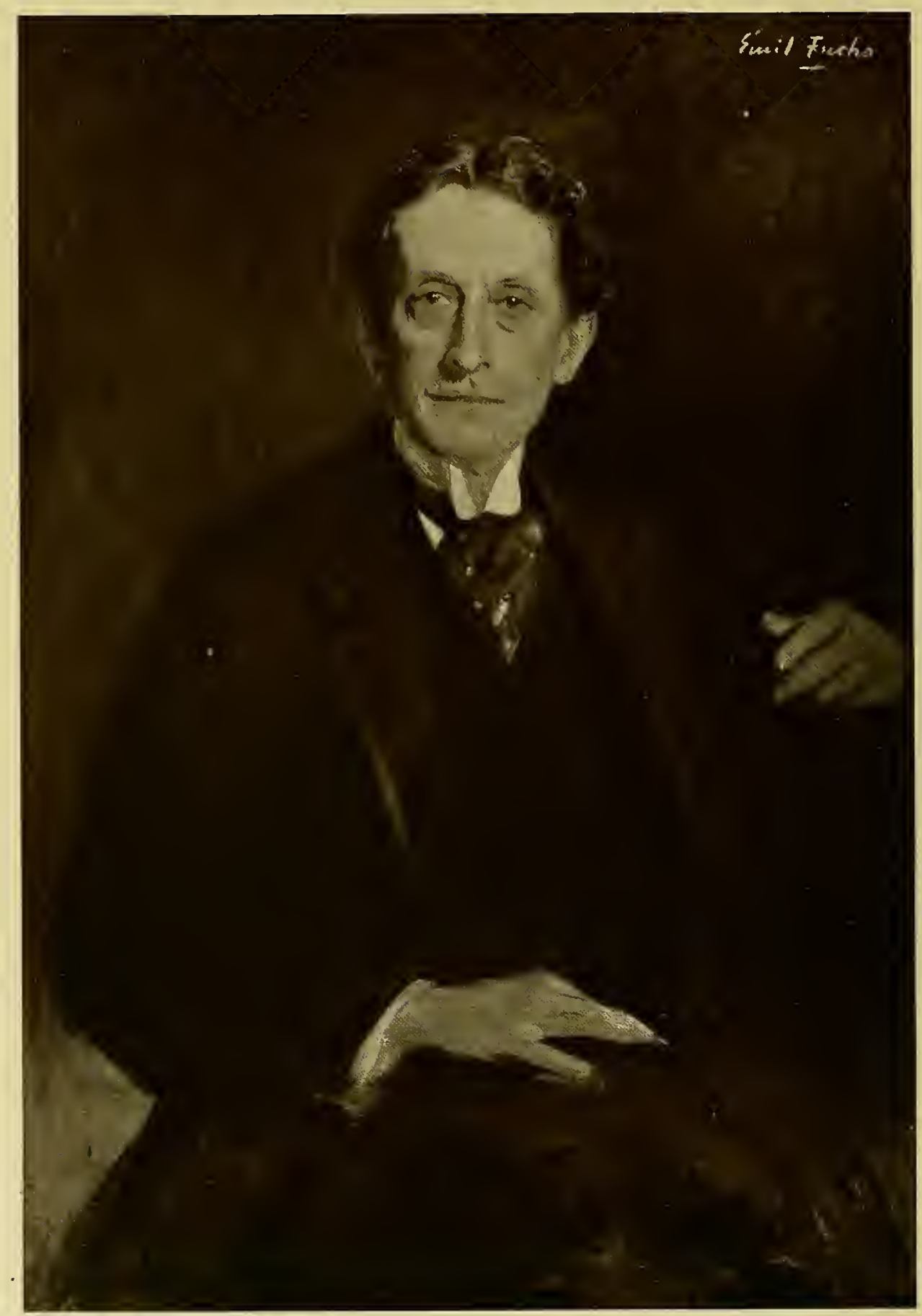

Sir Jobnston Forbes Robertson. 


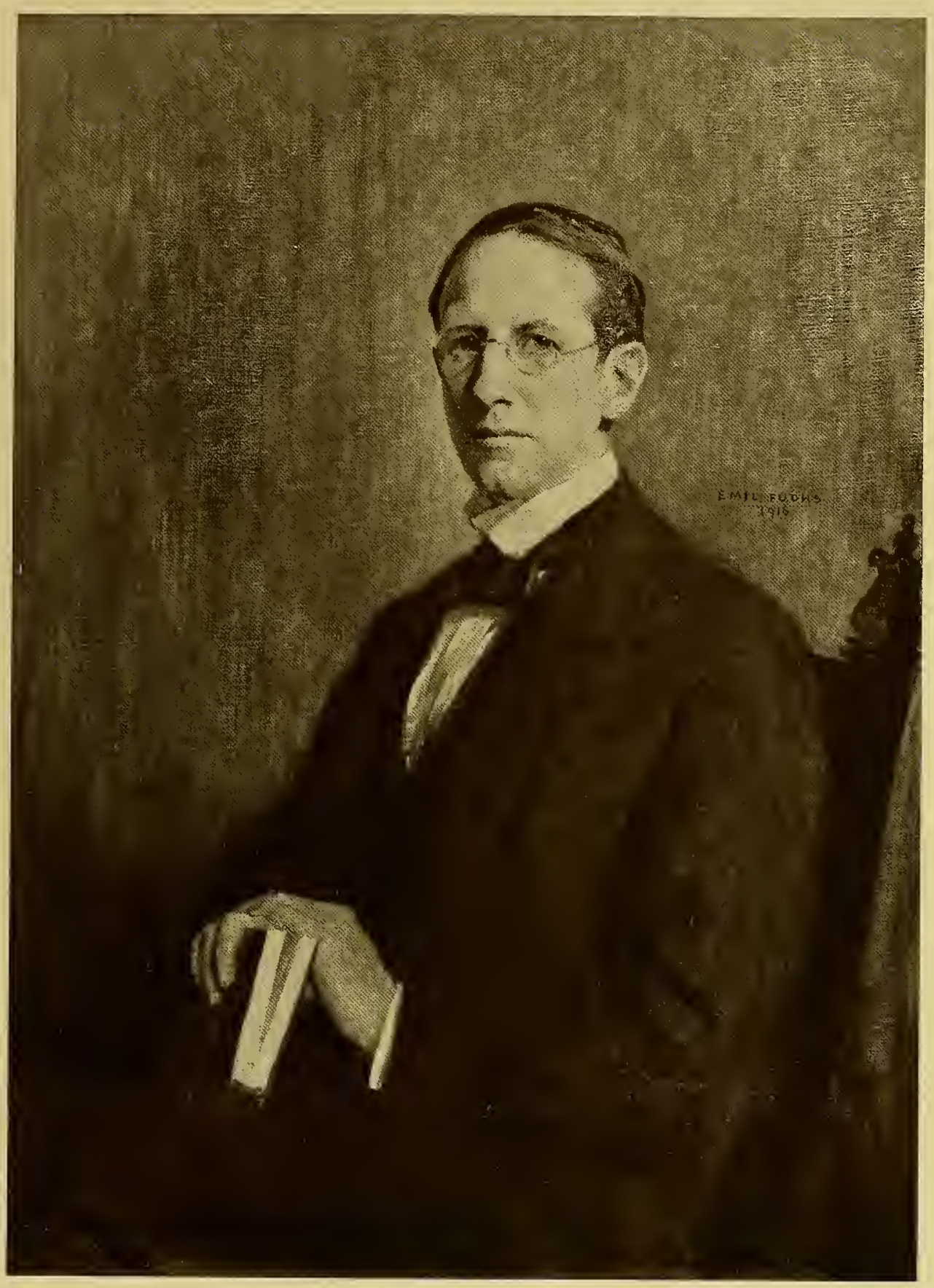

Henry OM. Earle 


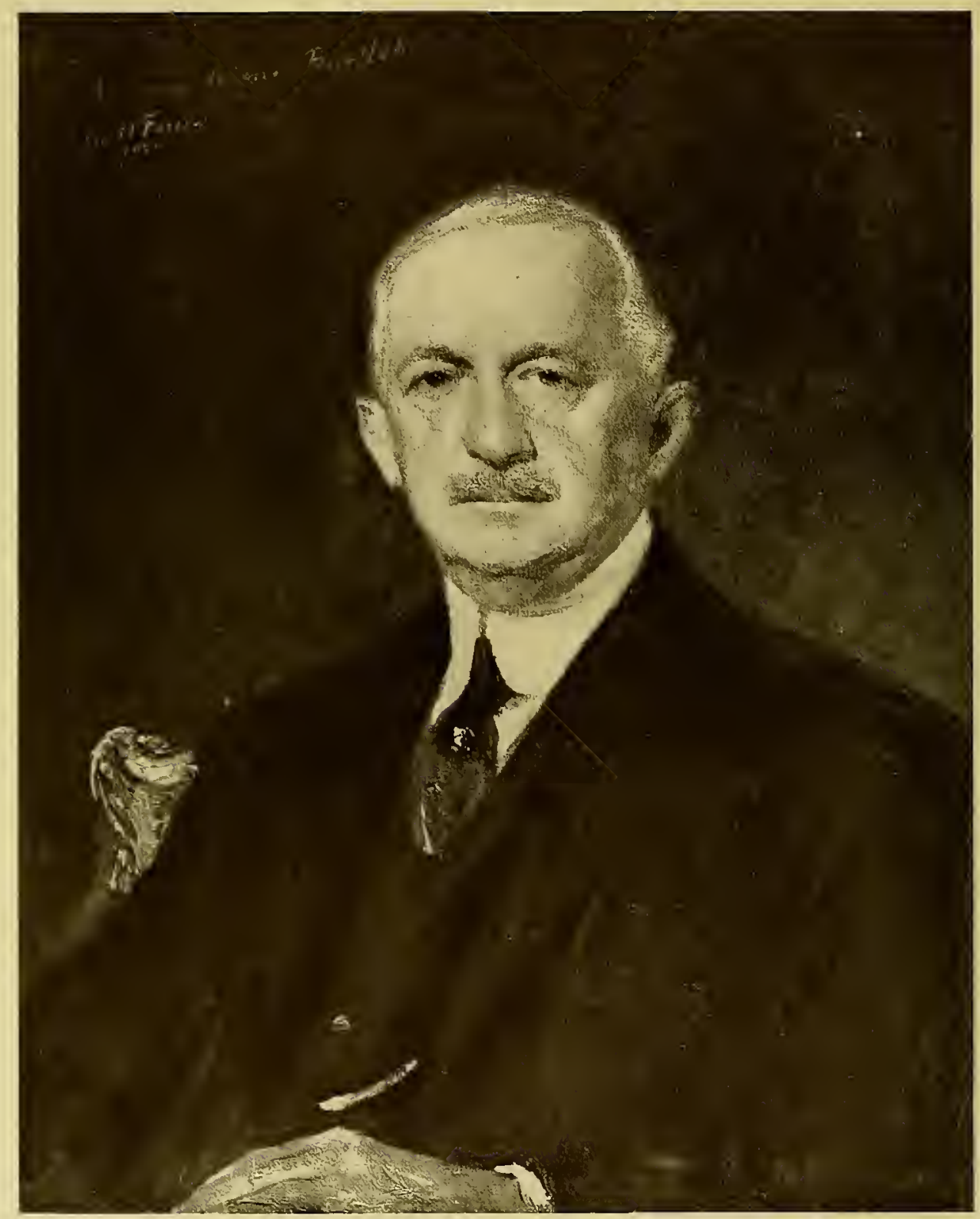

Edward E. Bartlett 


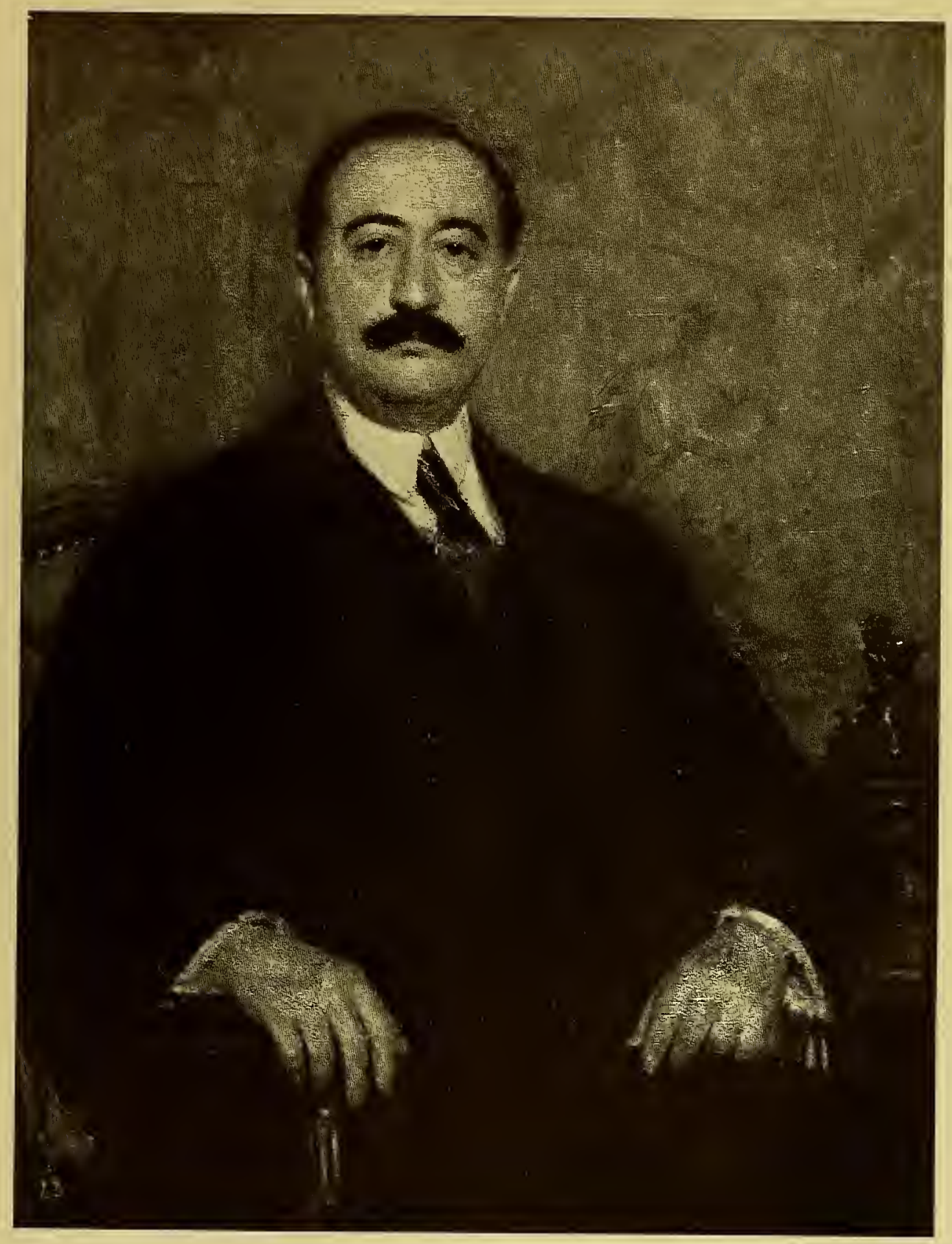

\section{Orestes Ferrara}

PROFESSOR OF THE NATIONAL UNIVERSITY OF HAVANA AND EX-SPEAKER OF THE HOUSE OF REPRESENTATIVES 


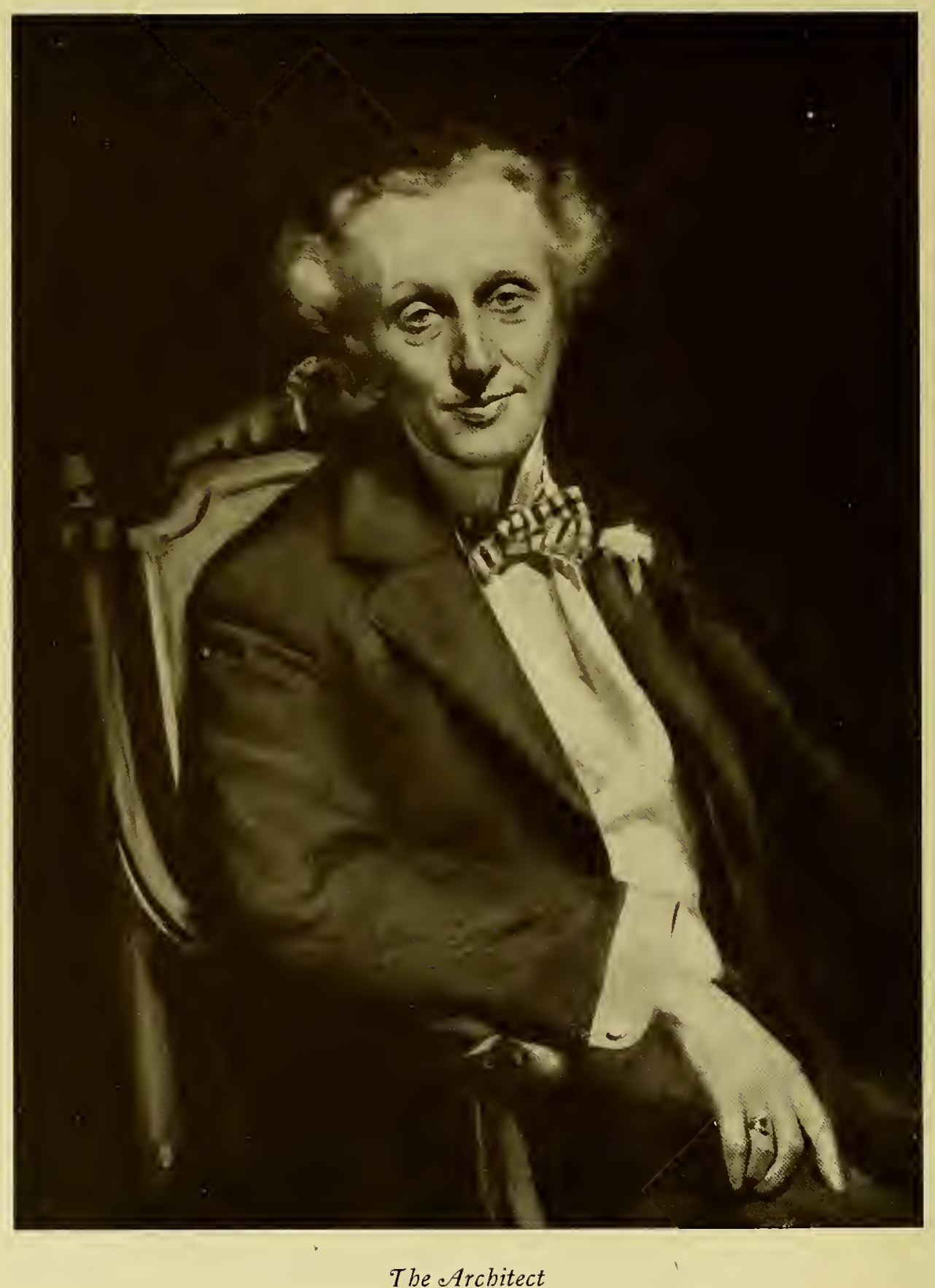

T be Arcbitect 
EMit rucns
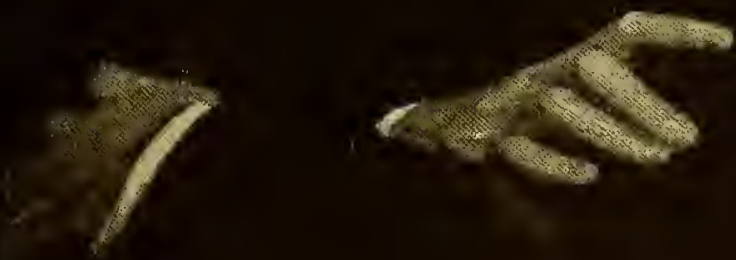

The late Howard $\mathcal{M}$. Beal, $\mathcal{M} . \mathcal{D}$. HEAD OF THE AMERICAN RED CROSS HOSPITAL, PAYNTON. ENGLAND 


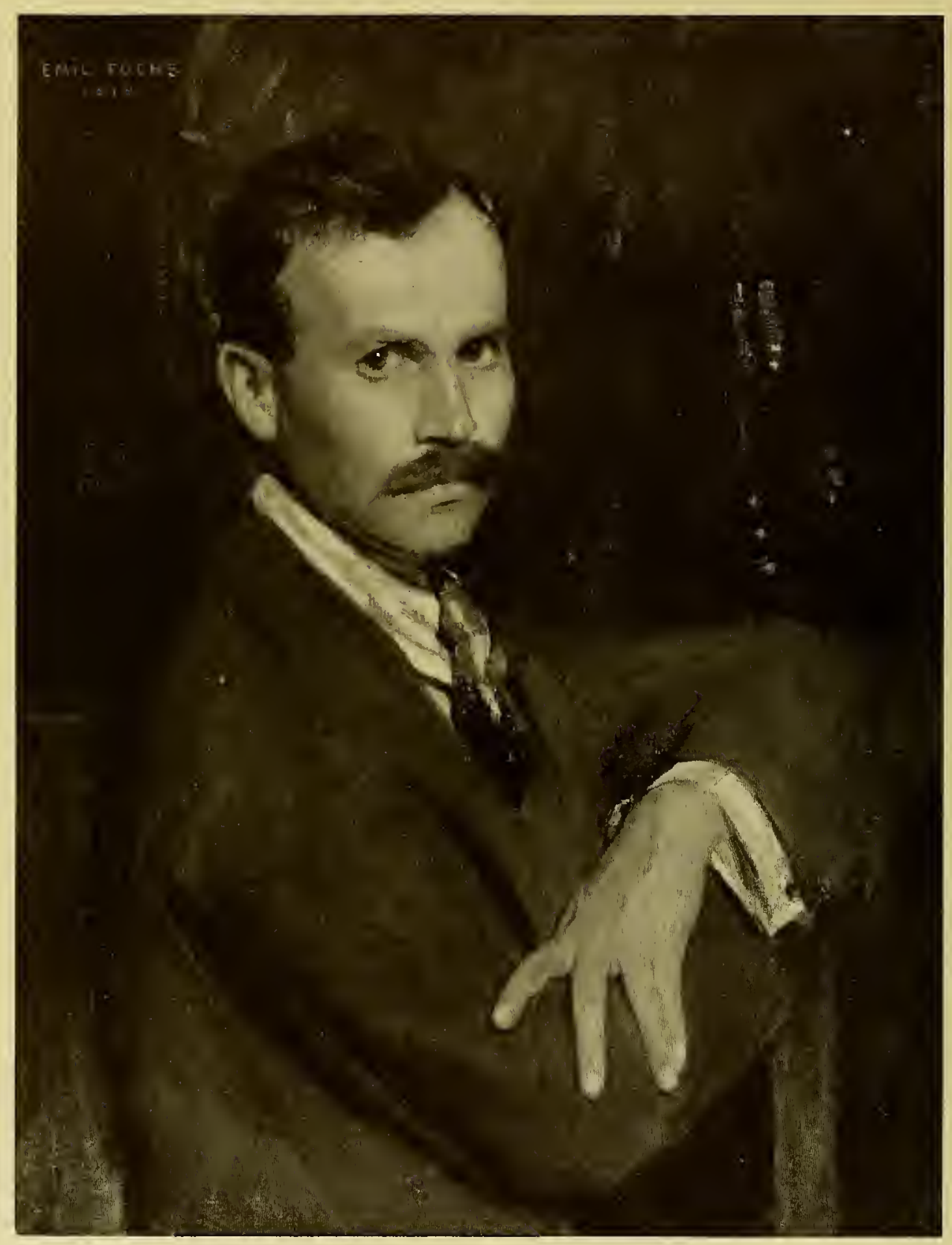

- Olariin Birnbaum 


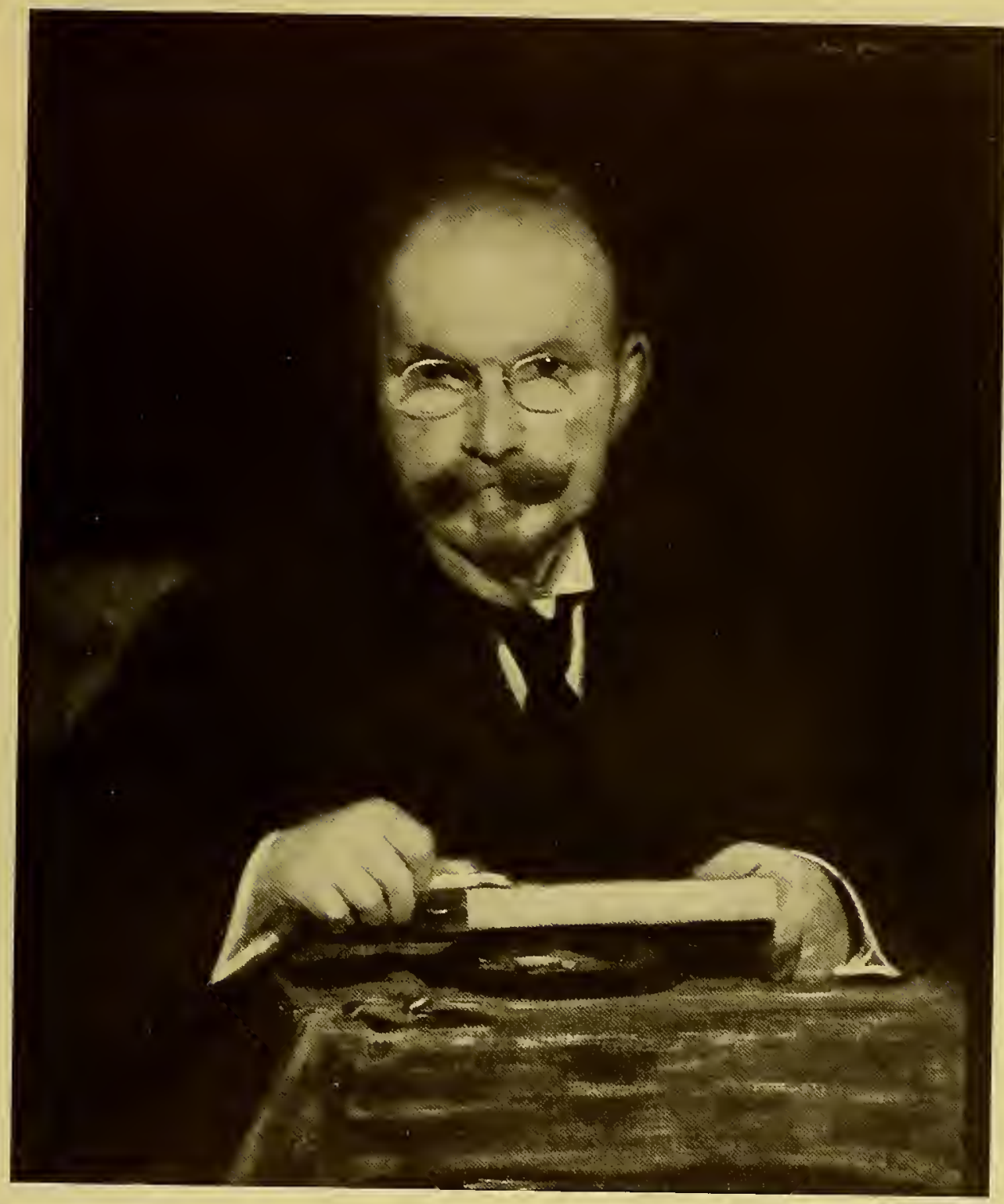

The Wood Engraver HENRY WOLF 


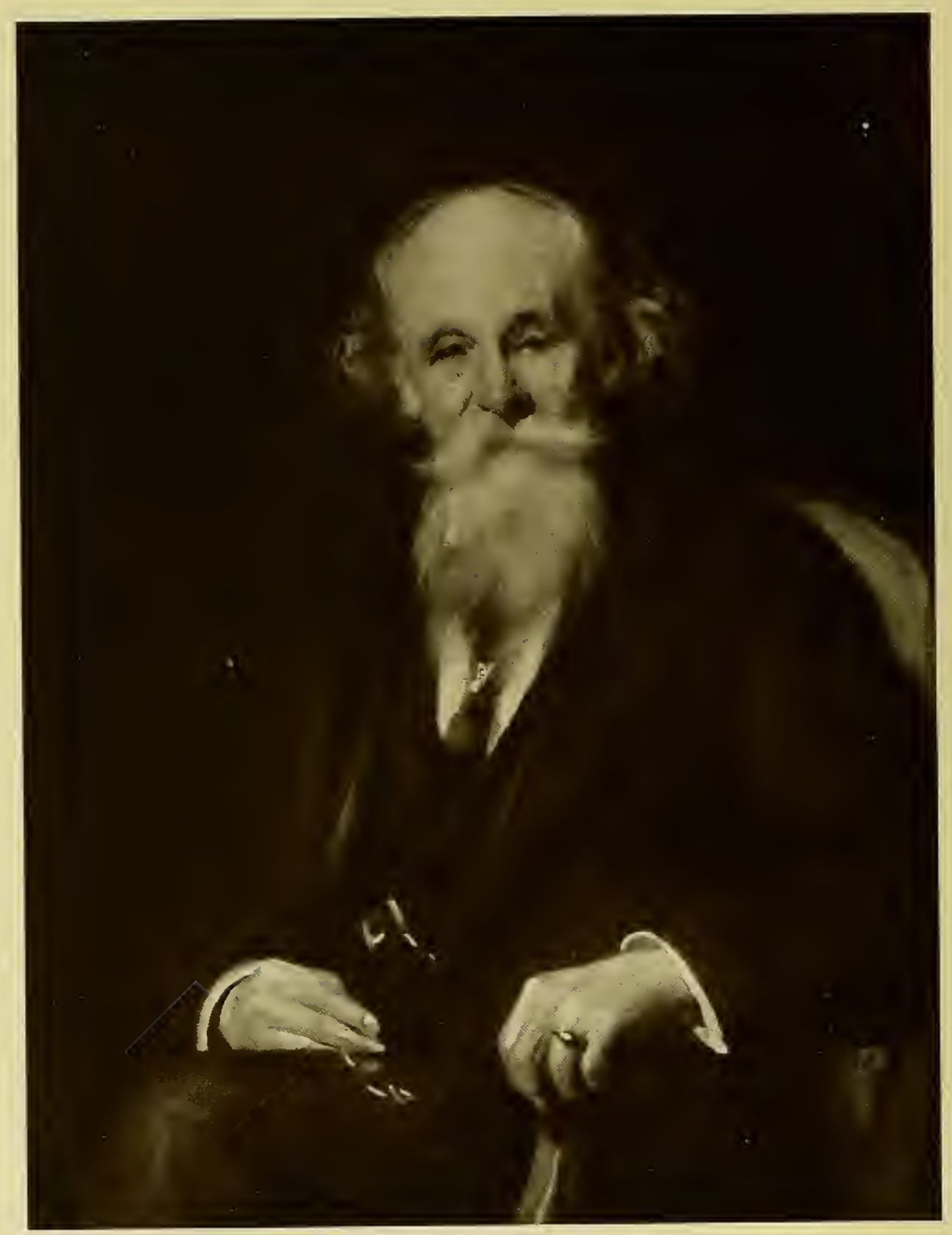

The Art Dealer

MARTIN COLNAGHI 


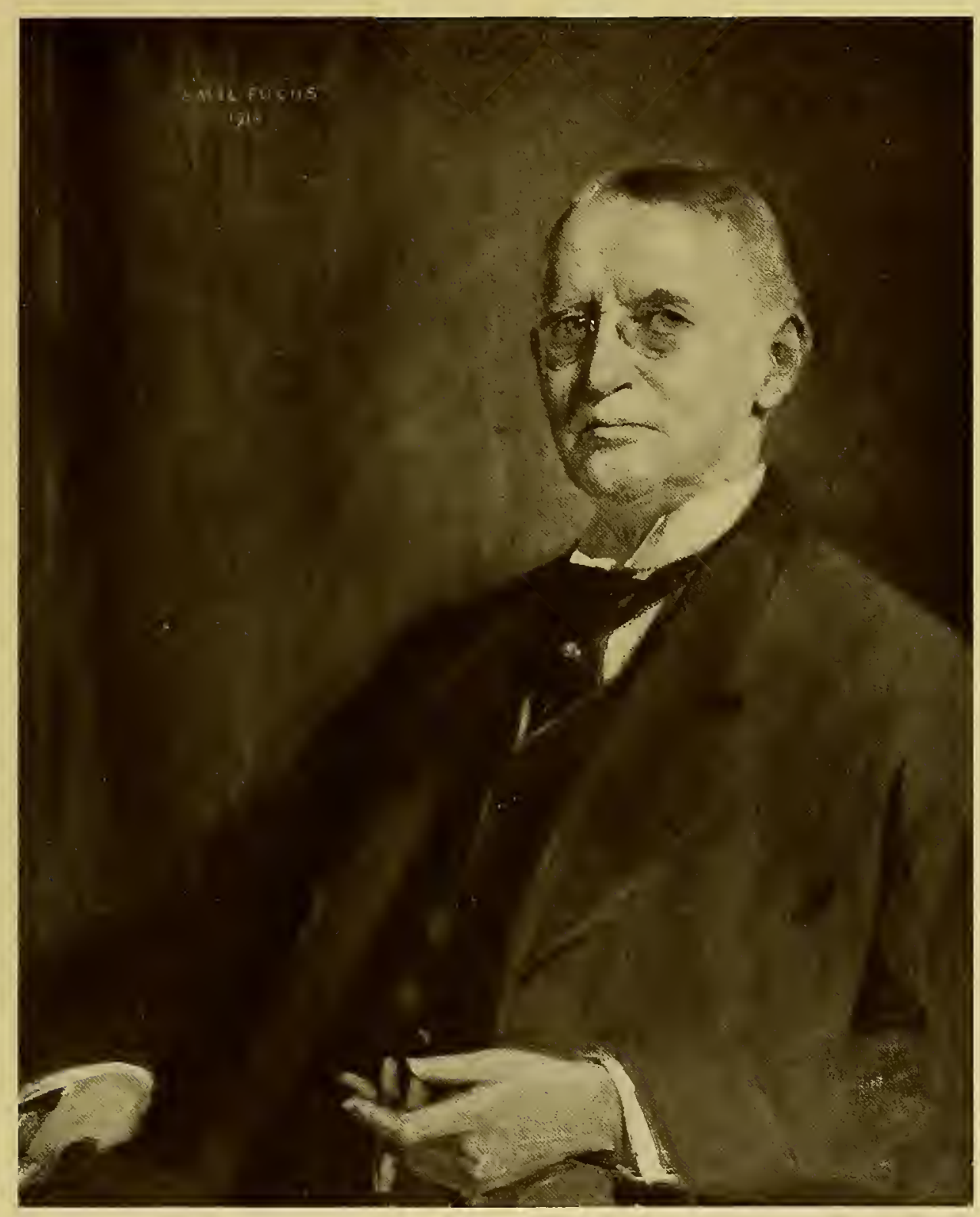

Trelville E. Stone

GENERAL MIANAGER OF THE ASSOCIATED PRESS 


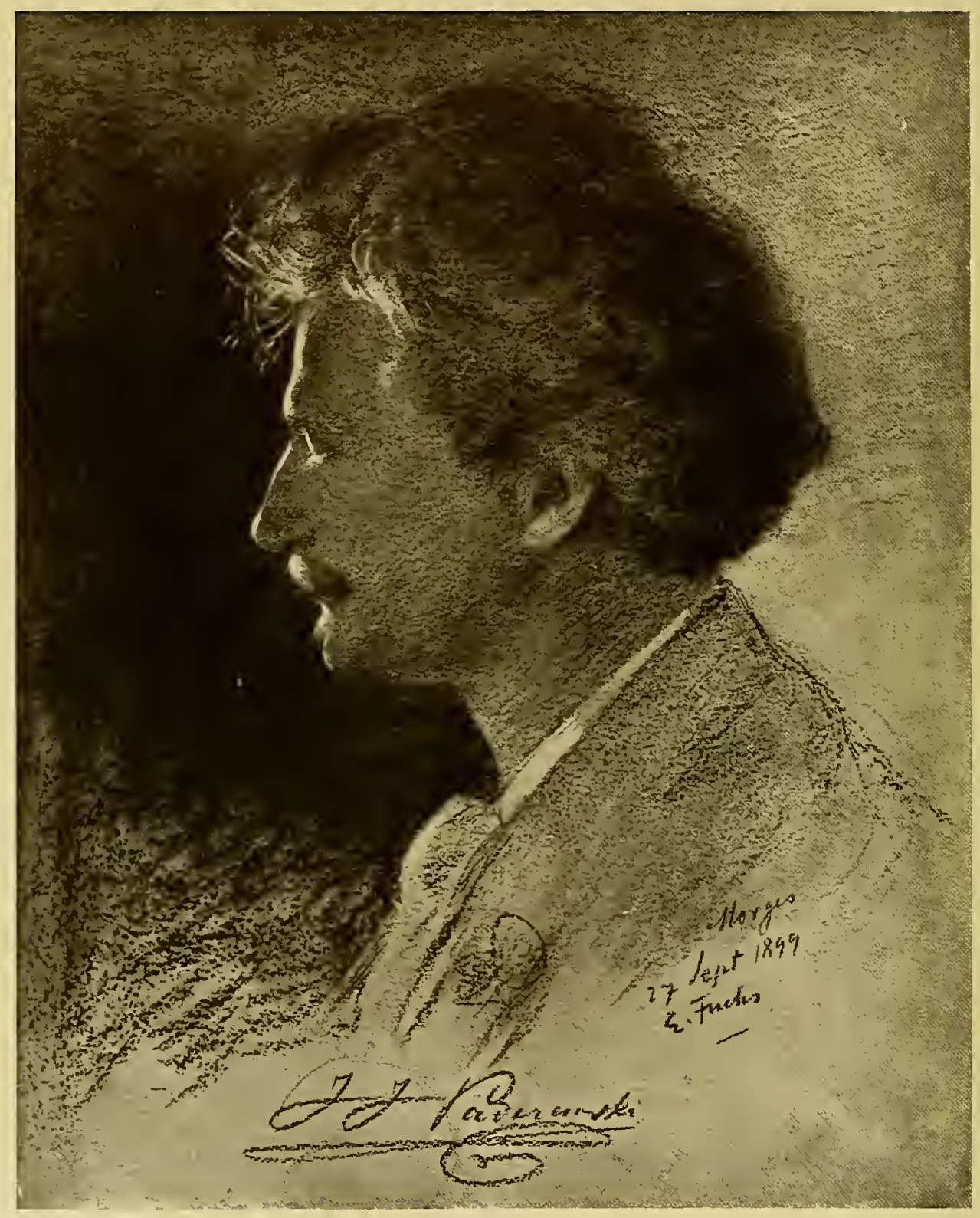

Paderewski 


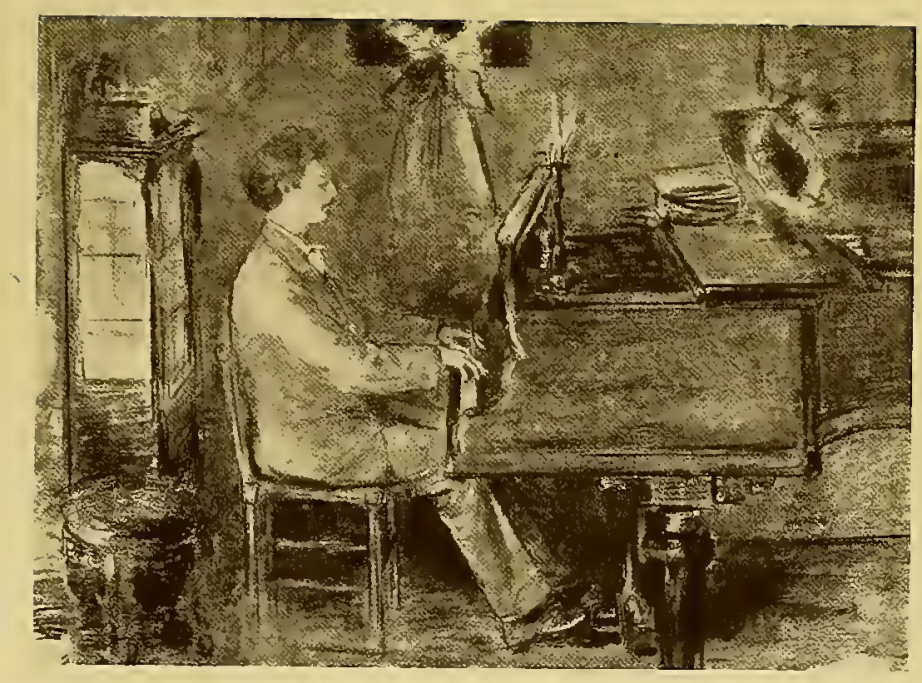

Paderewski at Home 


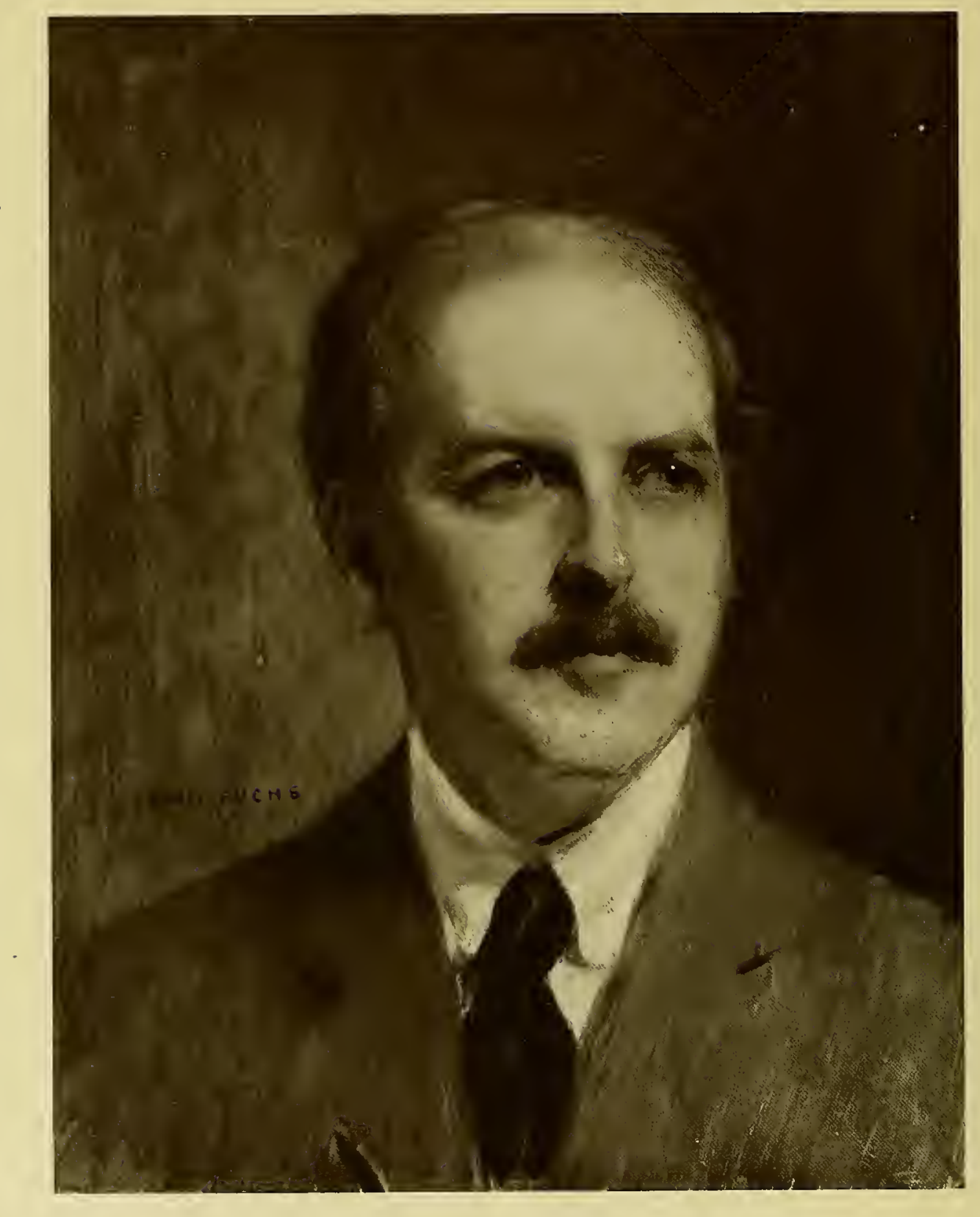

William A. Evans 


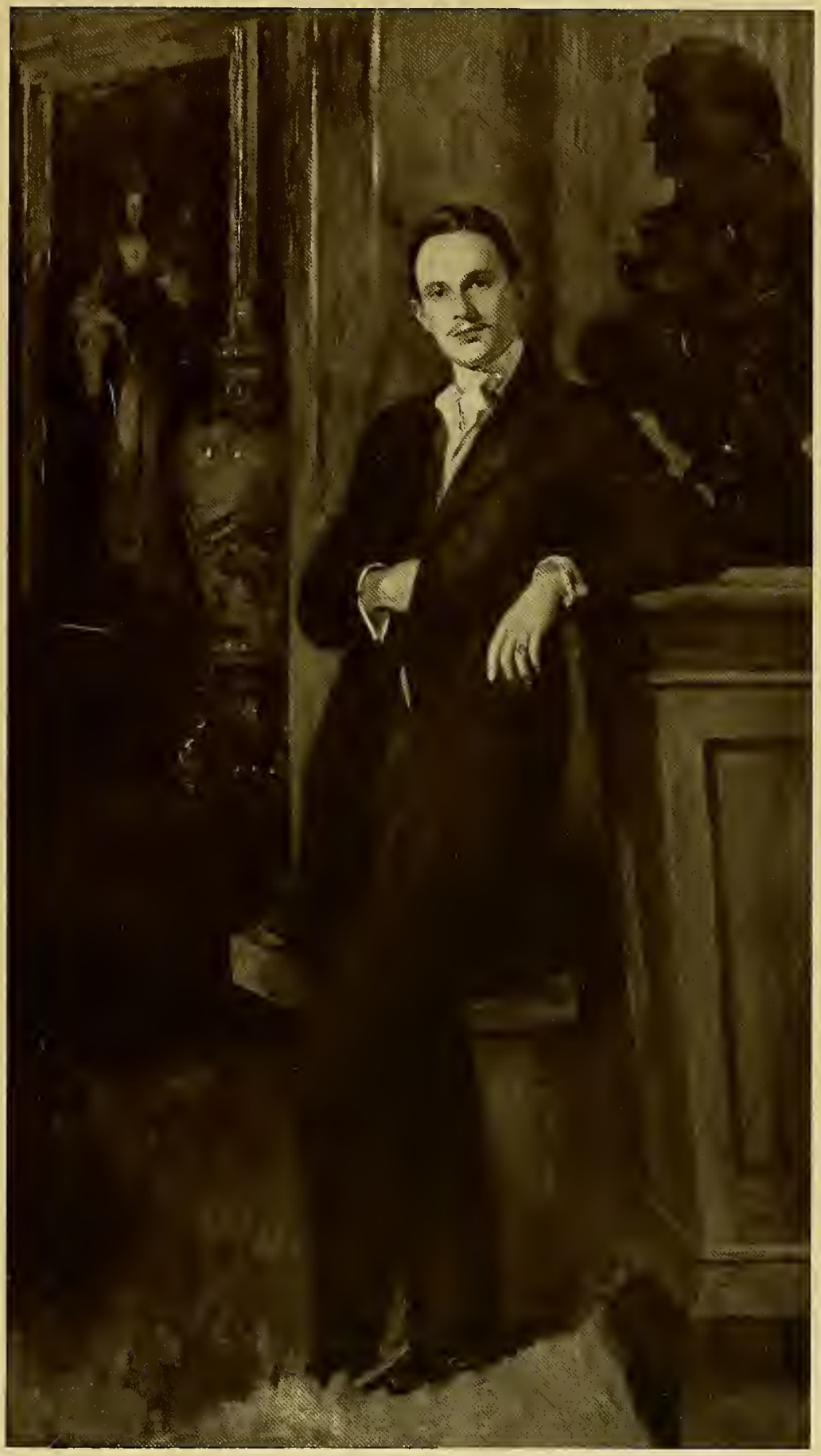

Kingdon Gould 



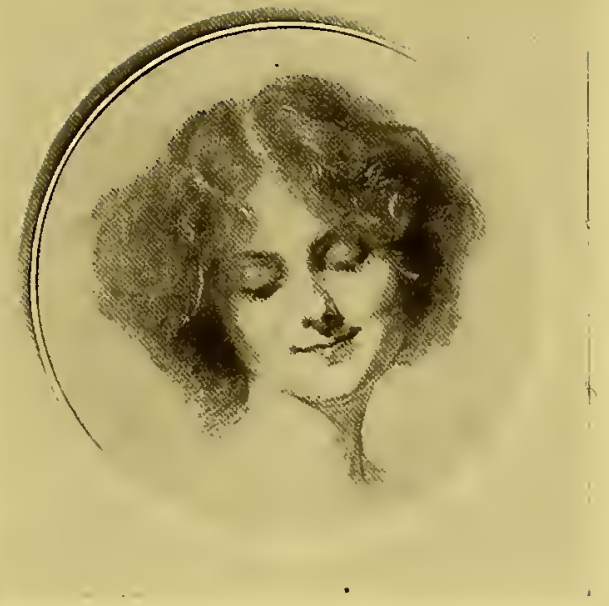




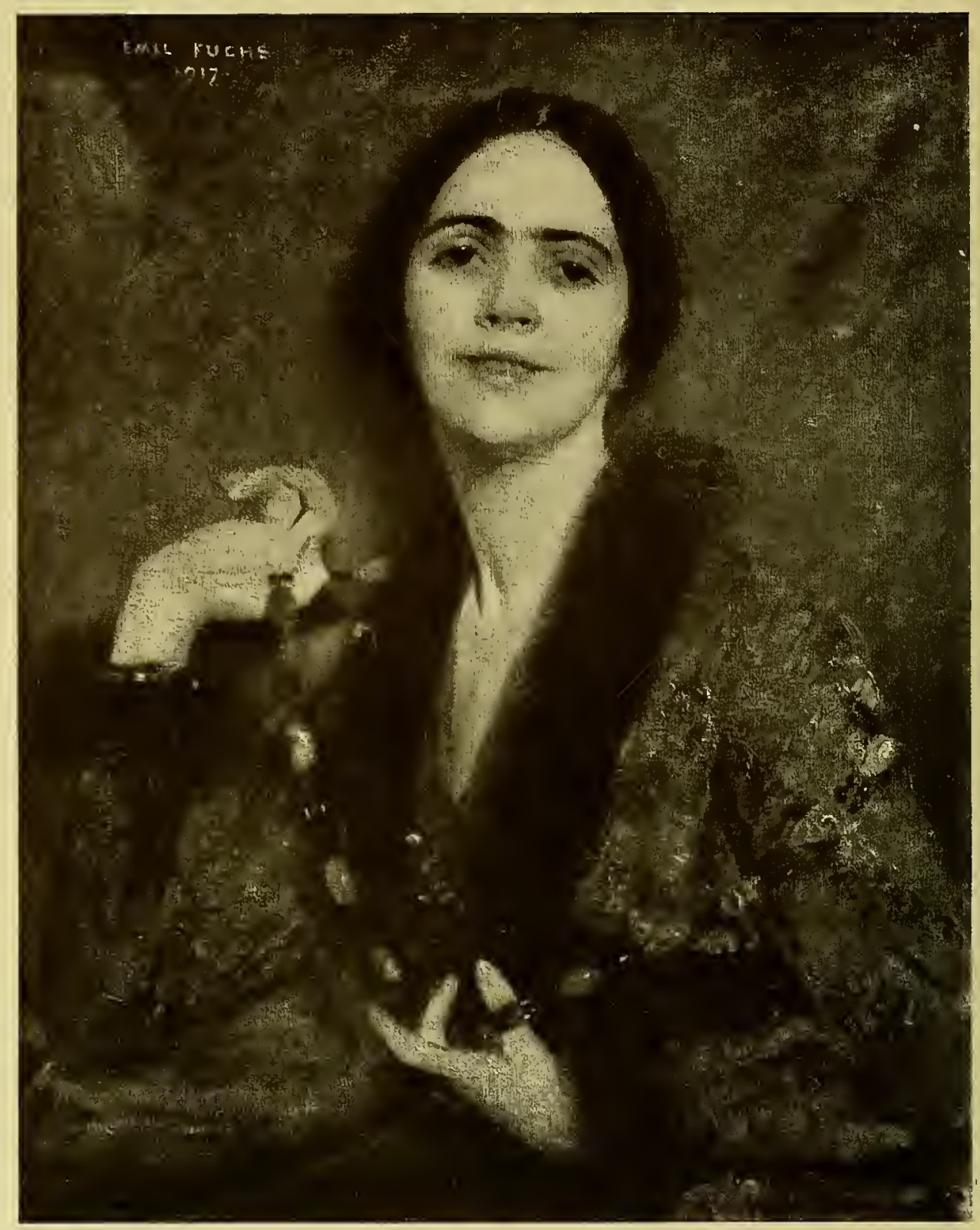

Roshanara 


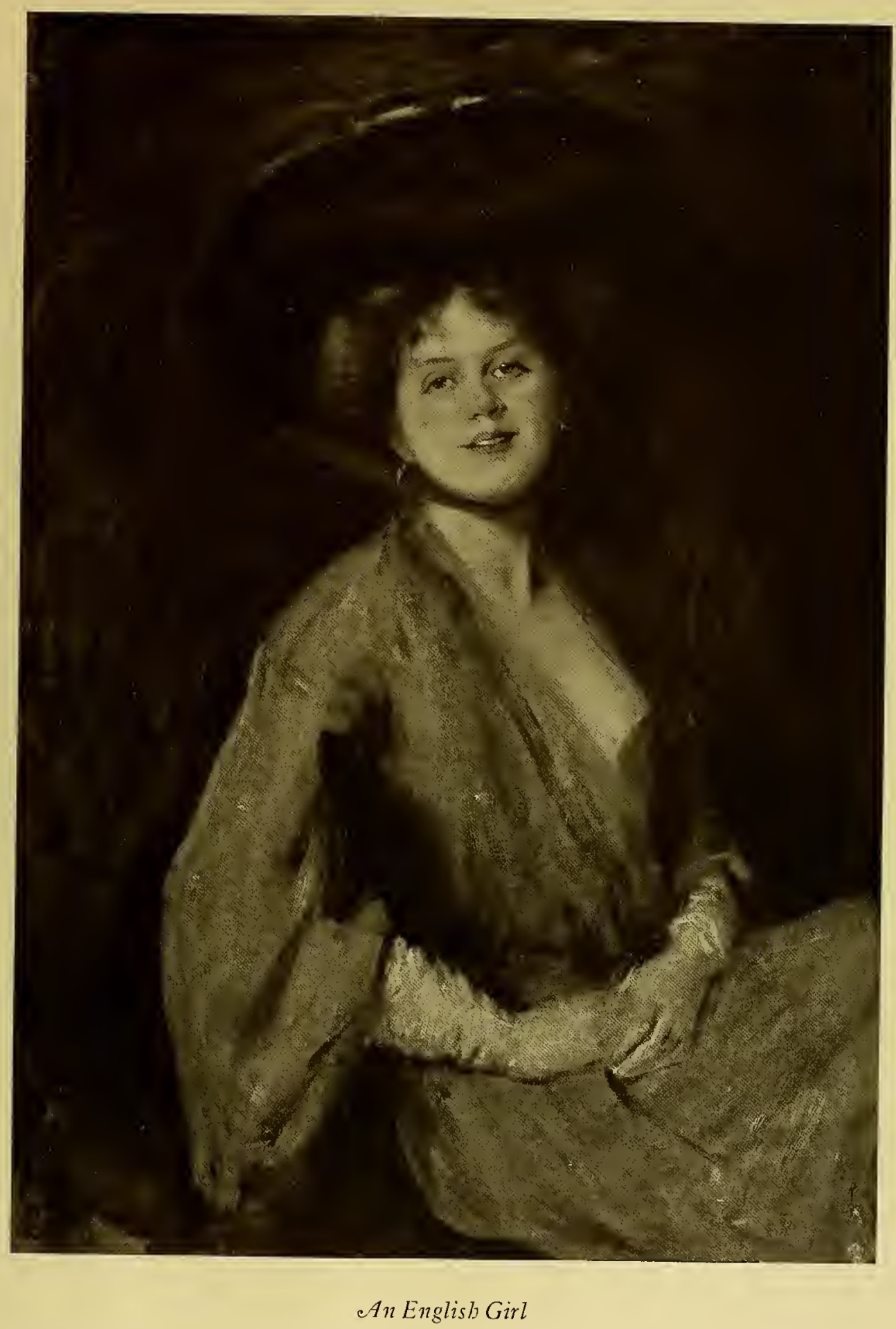




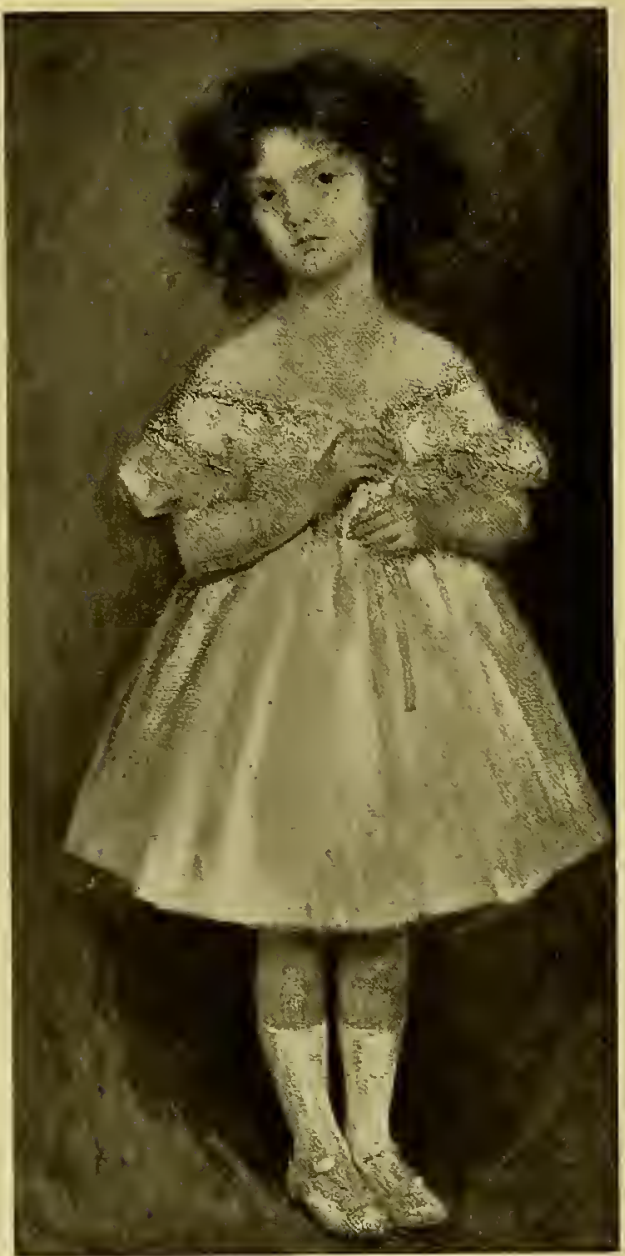

Little Jane 


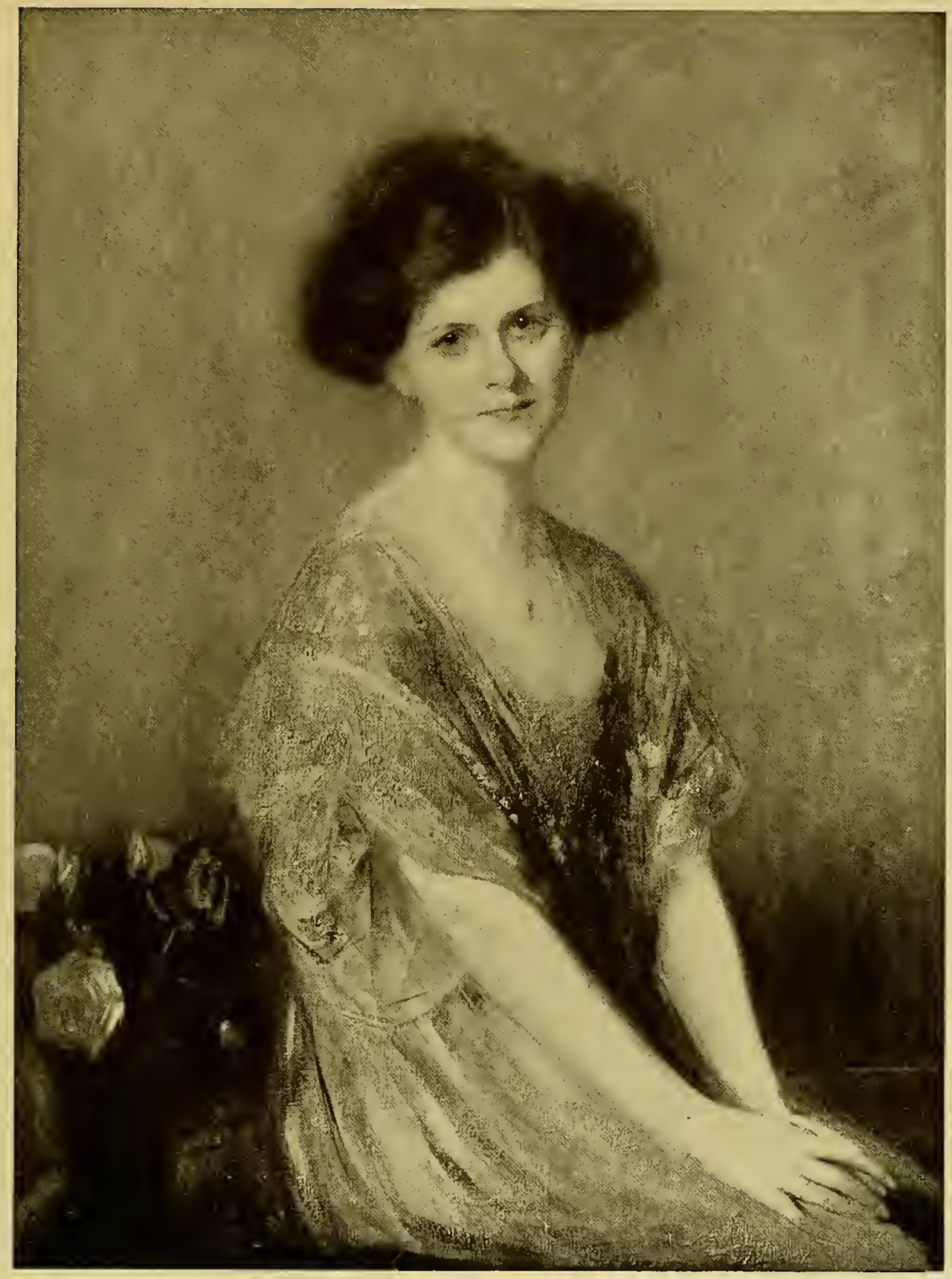

A Study in Blue and Gold 


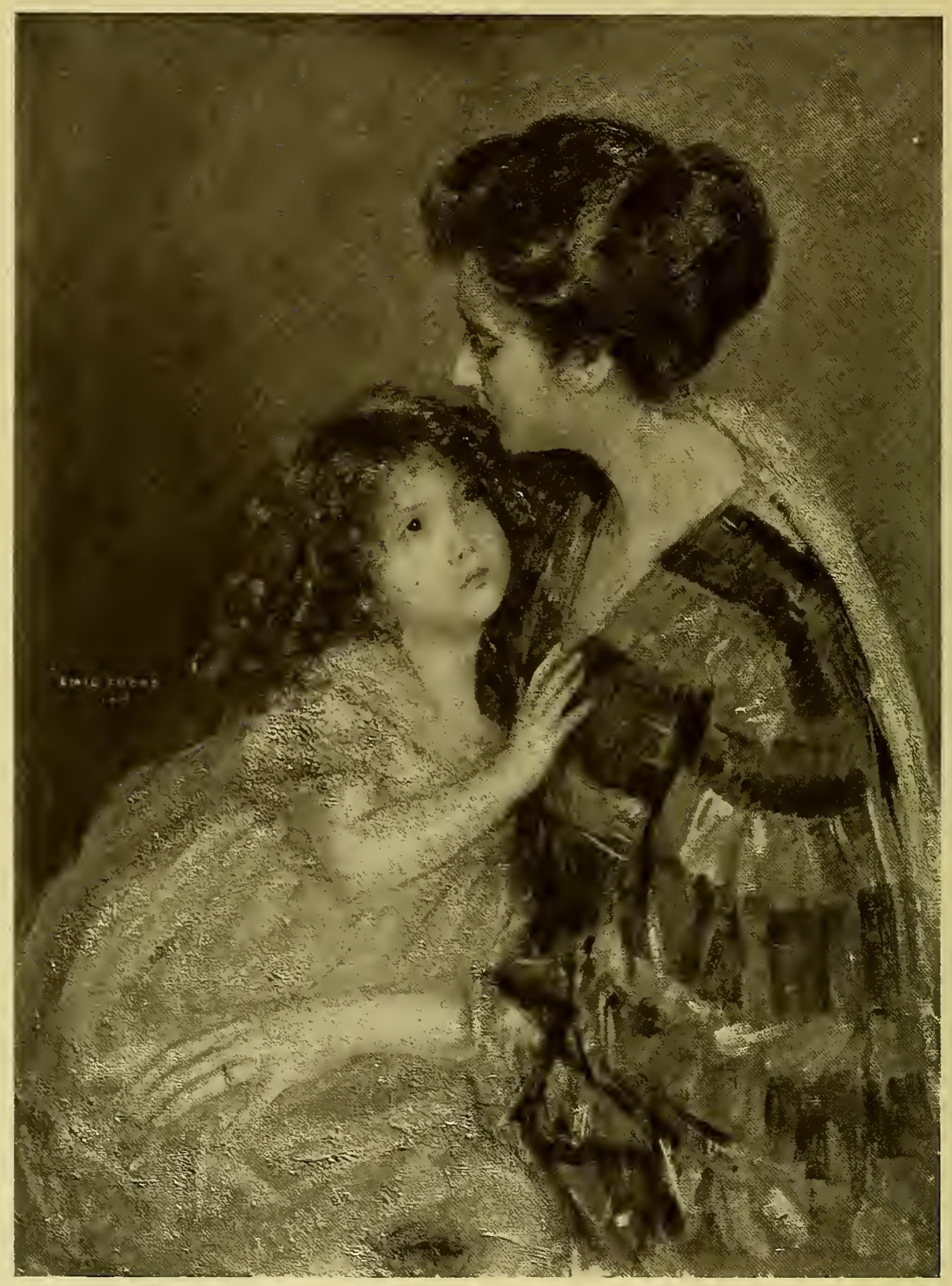

Little Jane and Her Mrother 


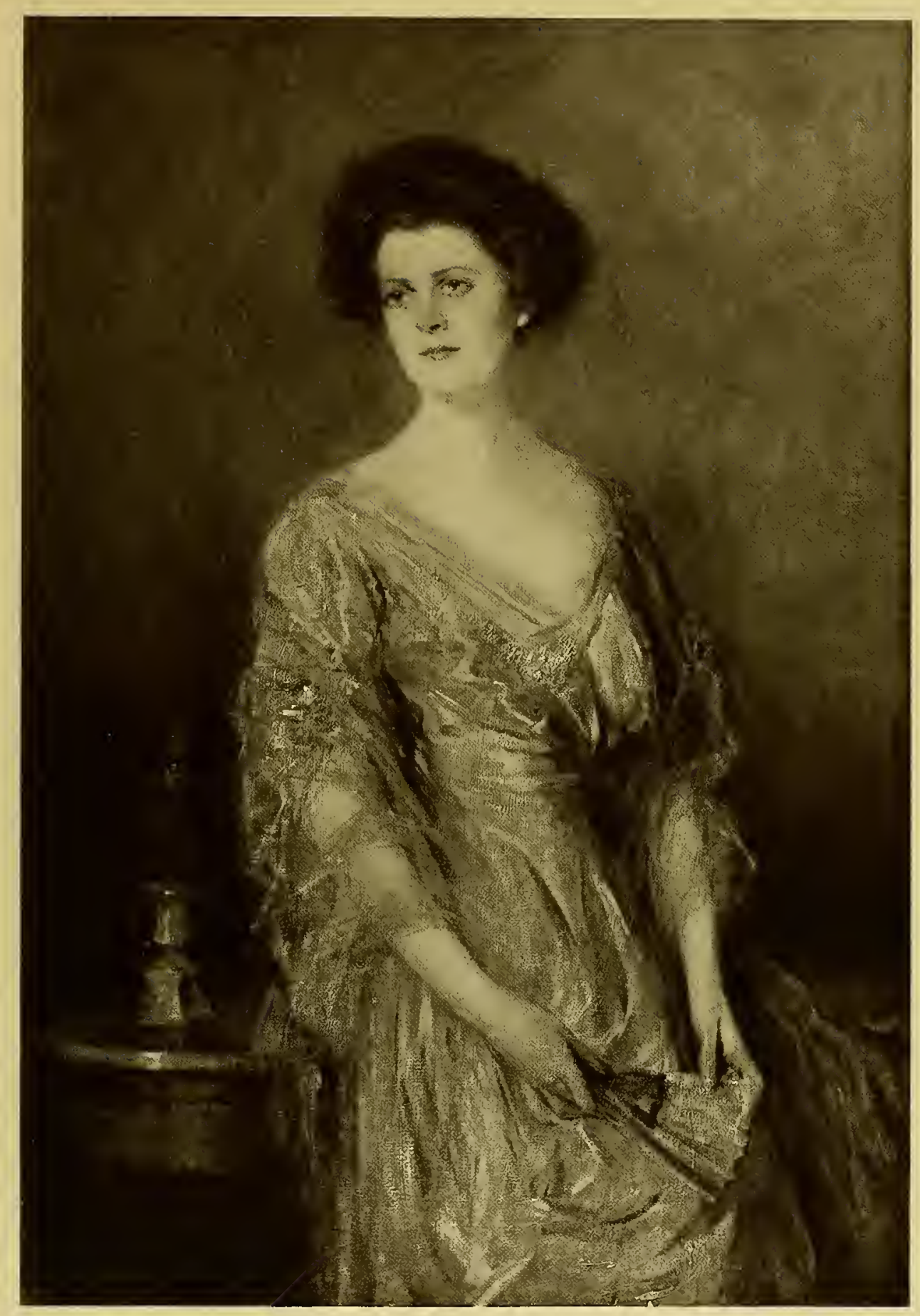

Mrs. Courtlandt Nicoll 


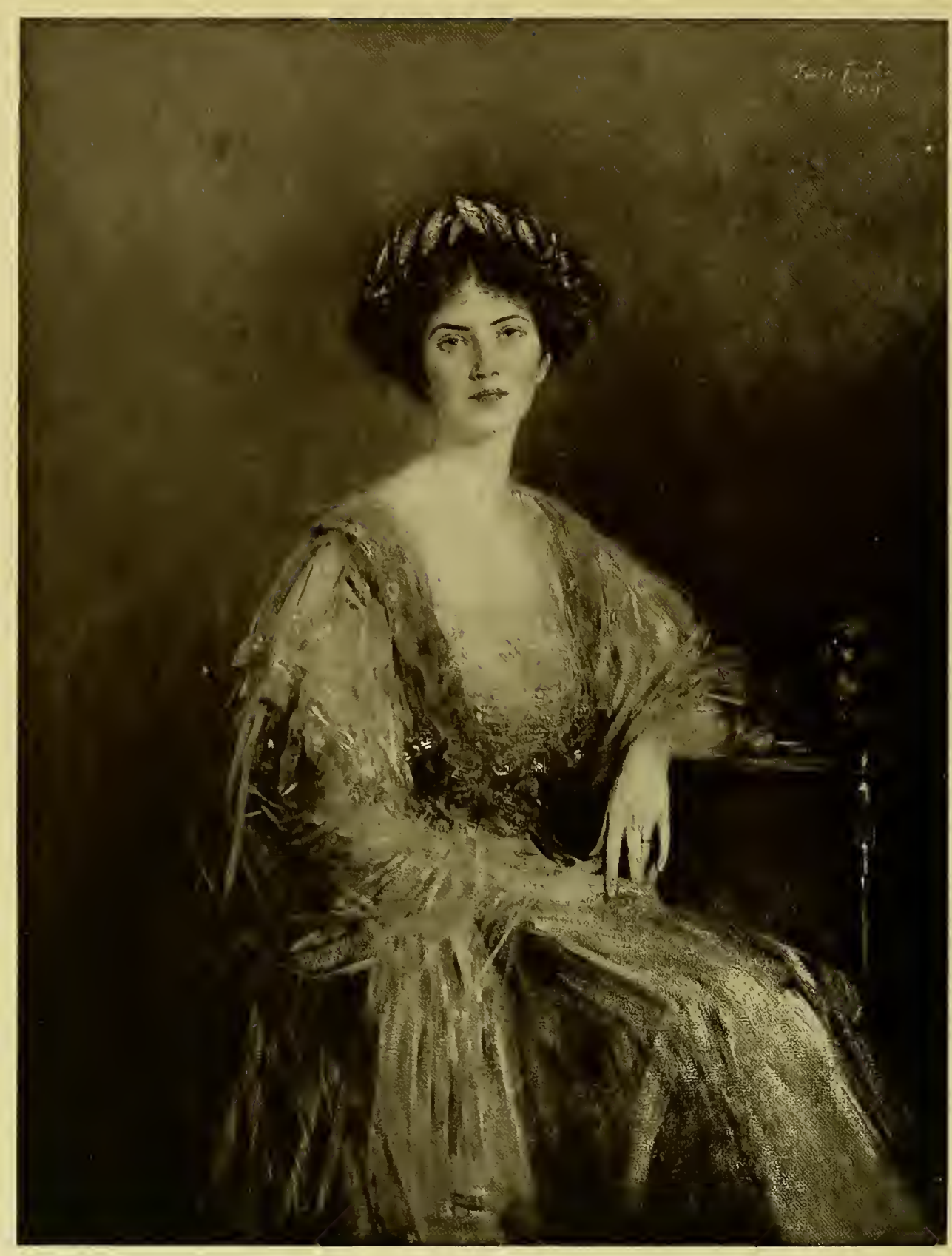

Mrs. Henry Clews, Jr. 


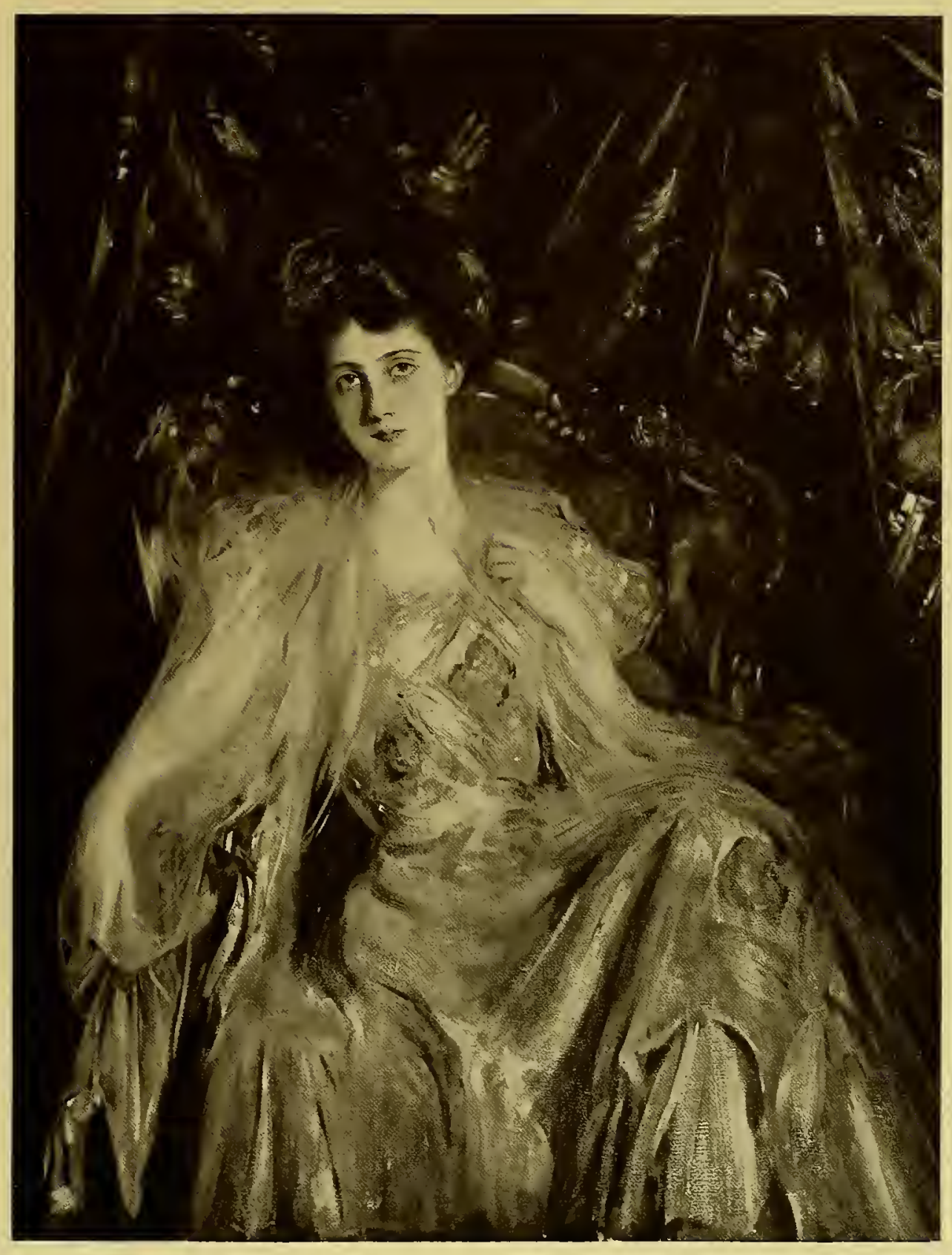

Adrienne de Carrière 

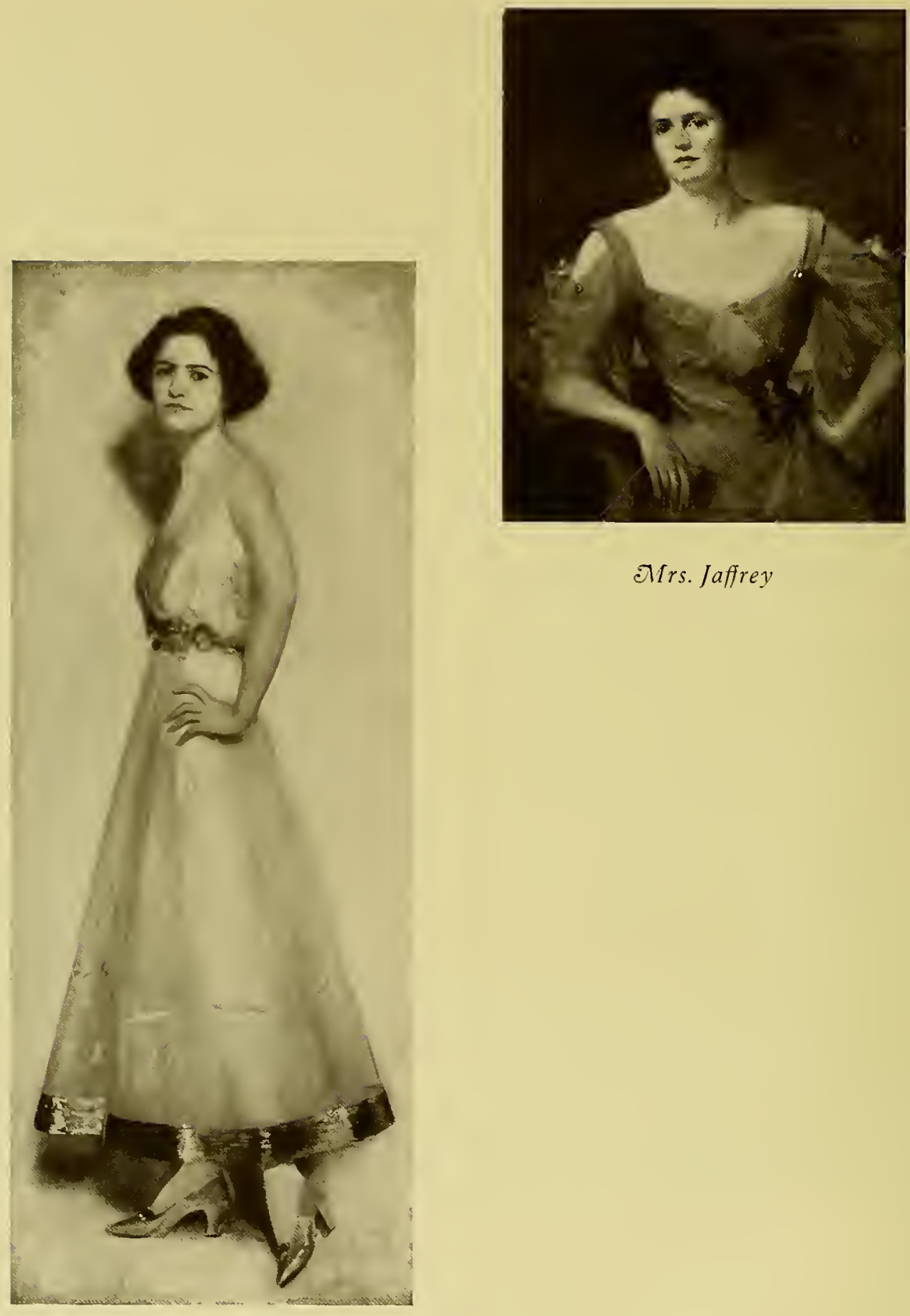

Mrs. Jaffrey

AMr. Allan Wellman 


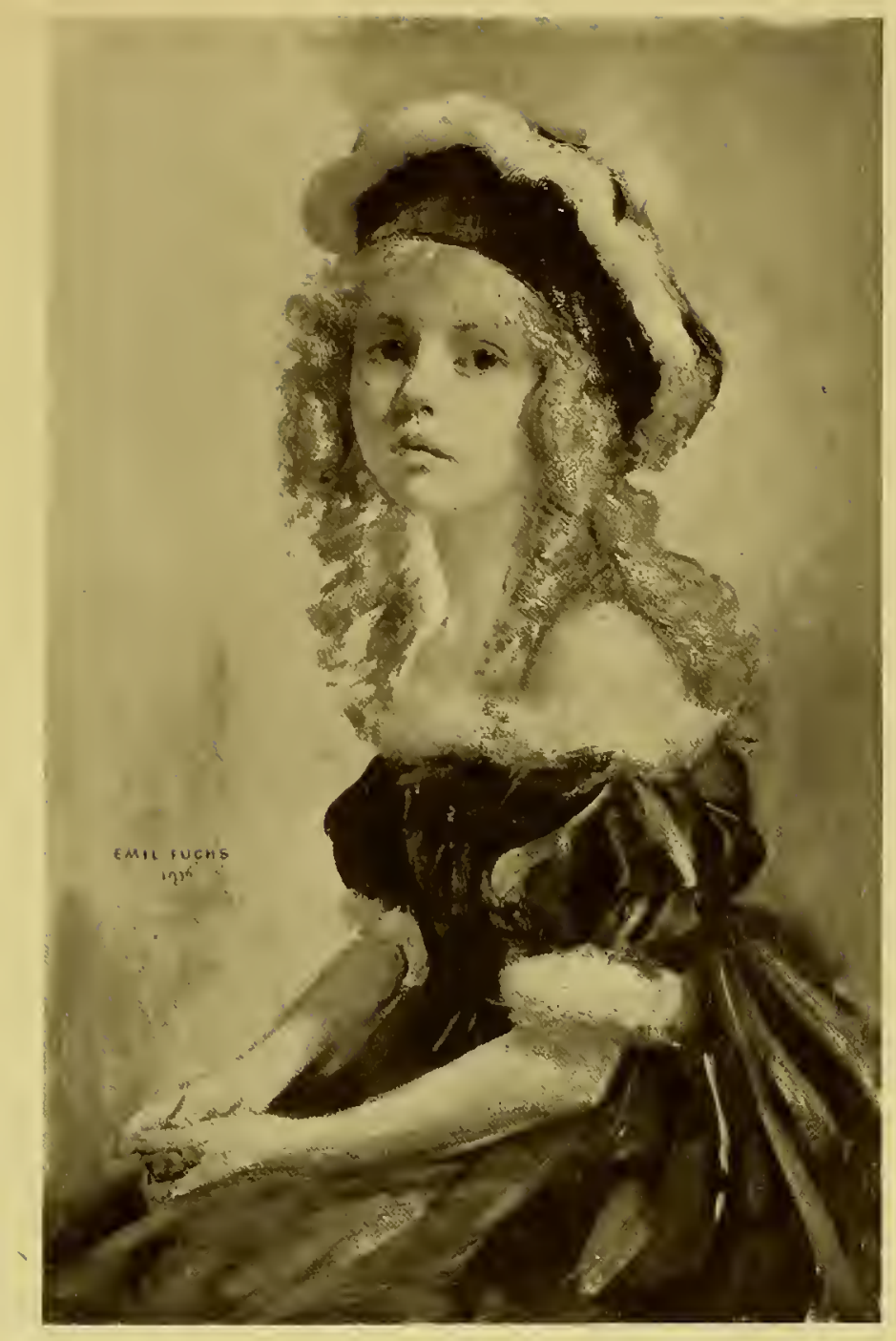

Etbelmary Oakland THE CHILD ACTRESS 


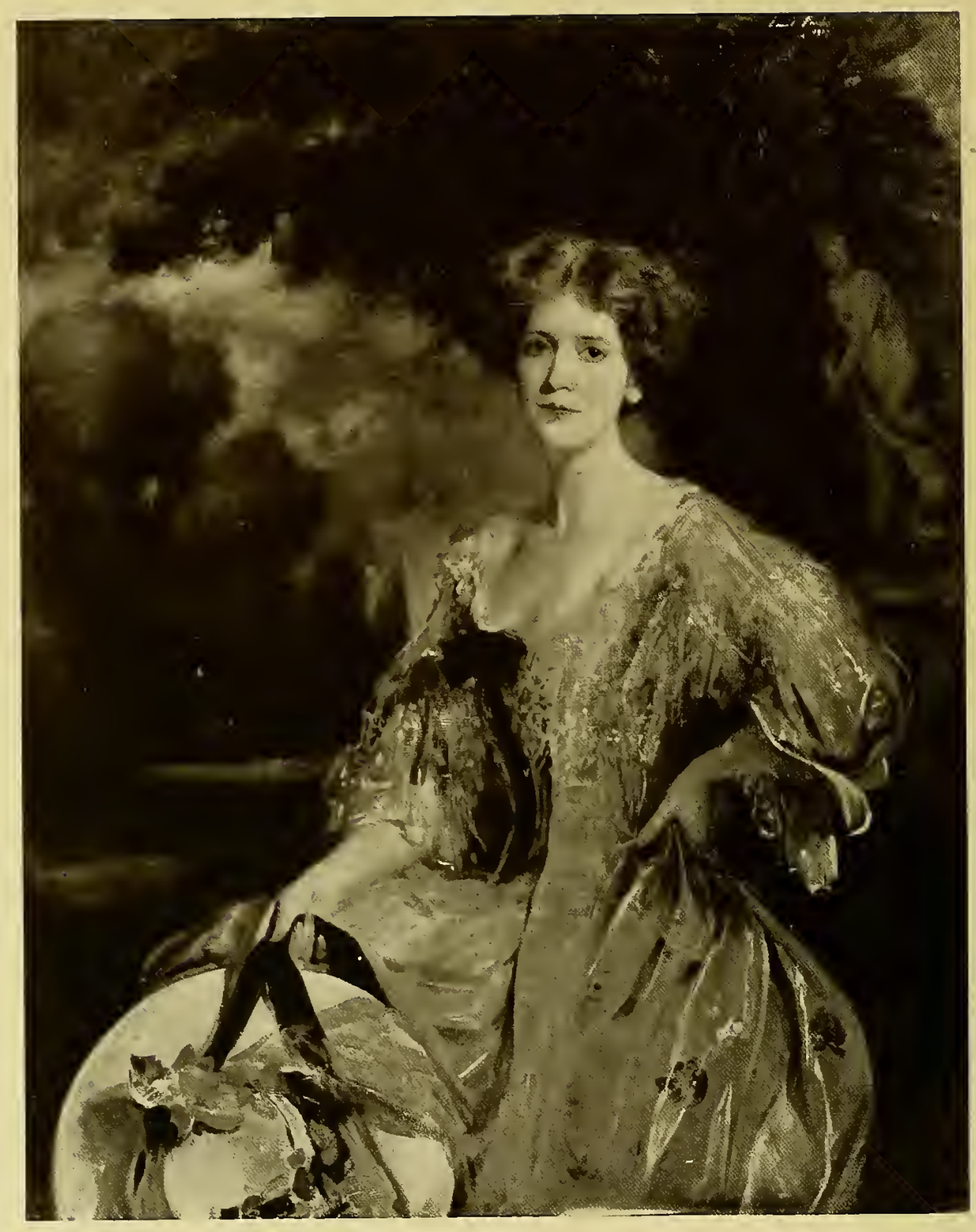

Mrs. Edmund C. Randolpb 


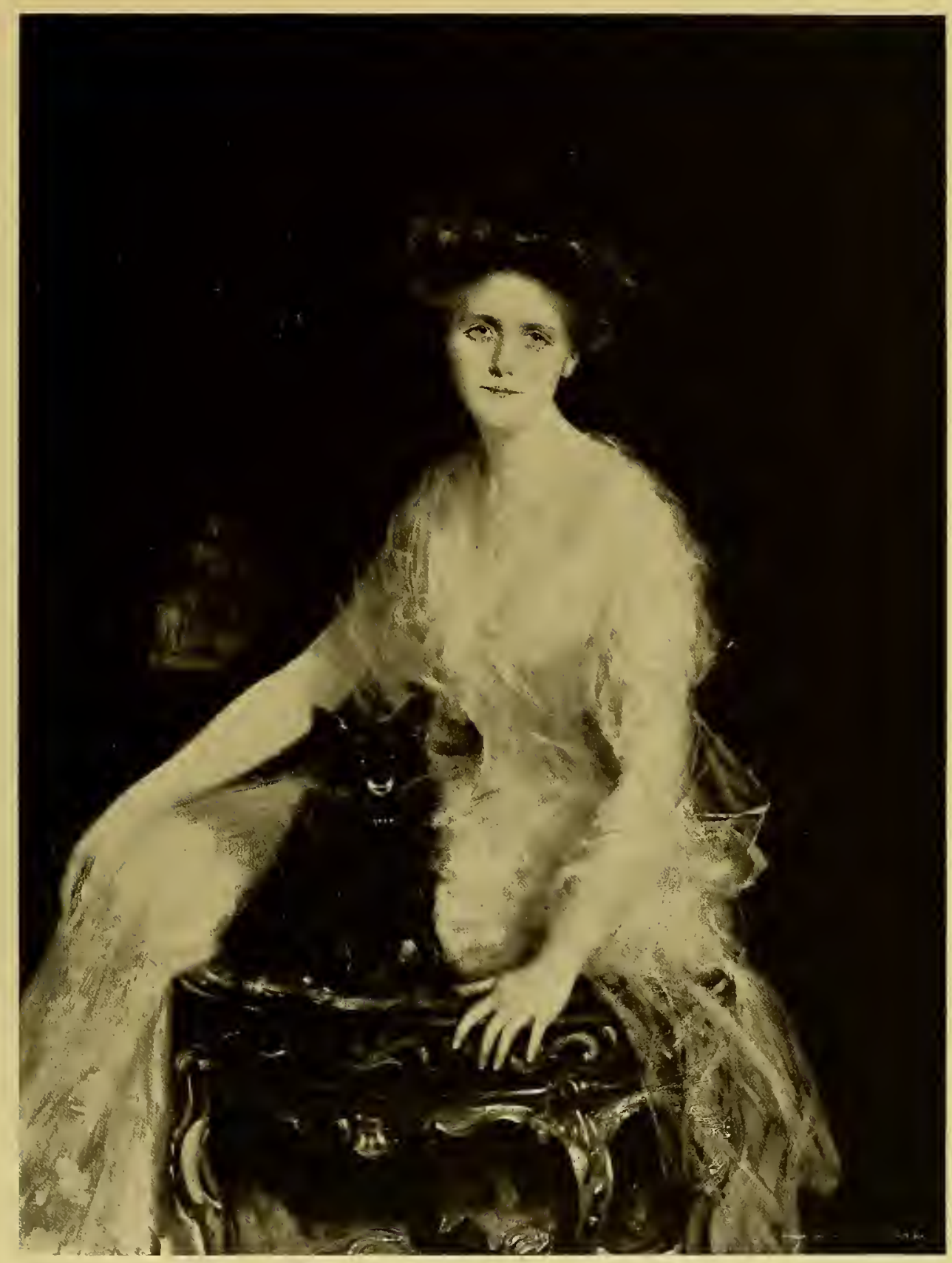

AIrs. ETarshall Field III 

MEDALS 


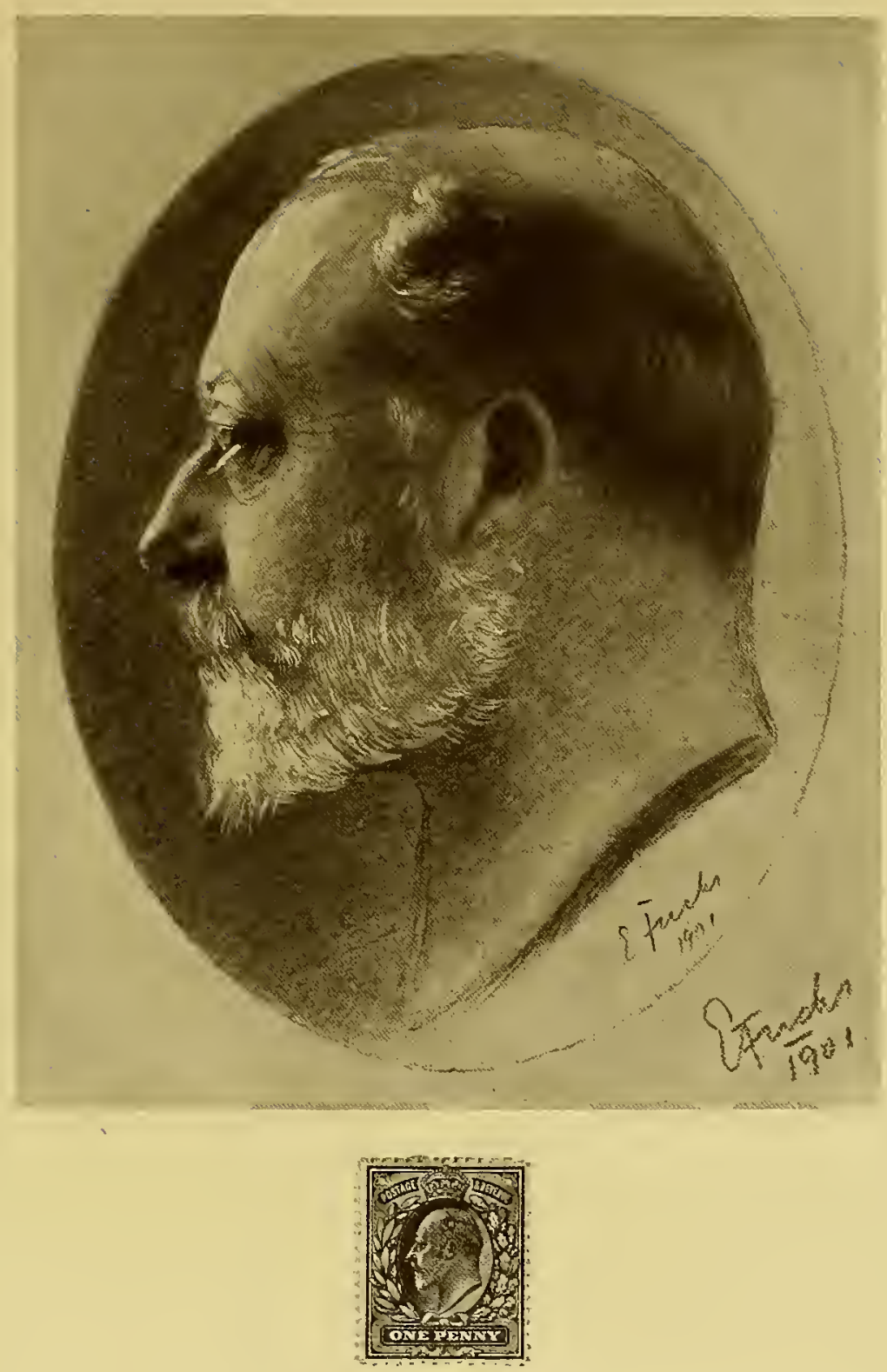

Drawing of the Head of King Edward VII for postage stamp

FROM THE ORIGINAL AT SOMERSET HOUSE, LONDON 

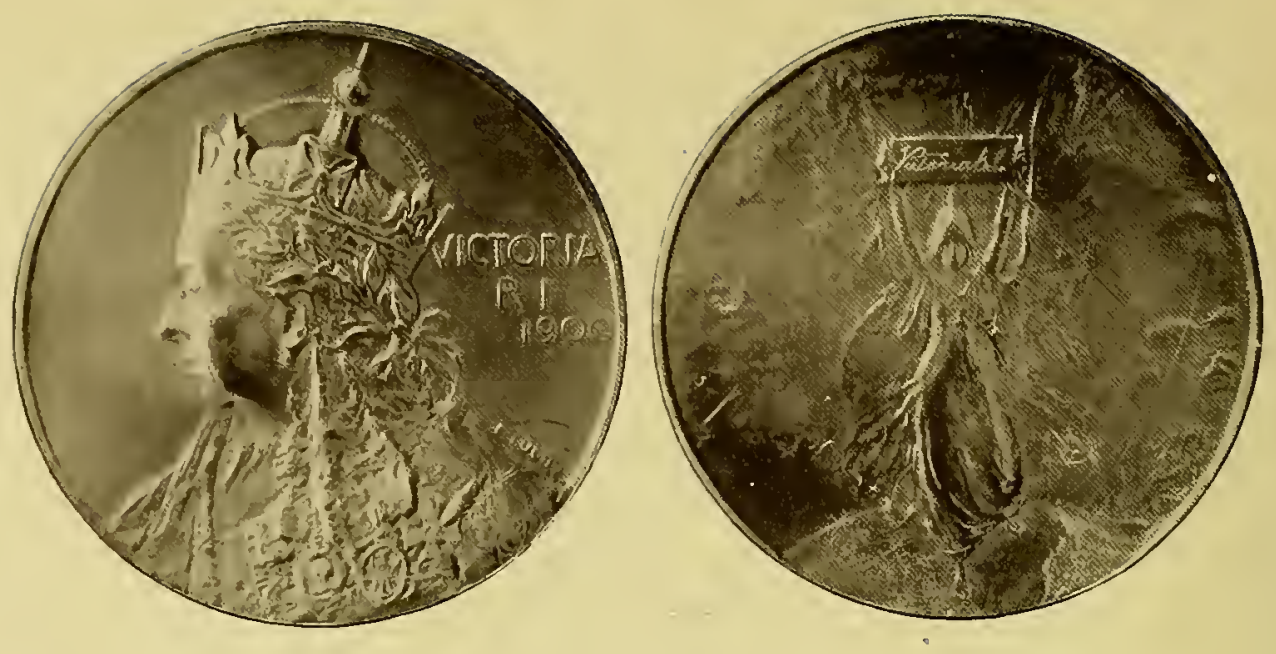

Queen Victoria

MEDAL COMMEMORATING HER REIGN IN THE TWENTIETH CENTURY 

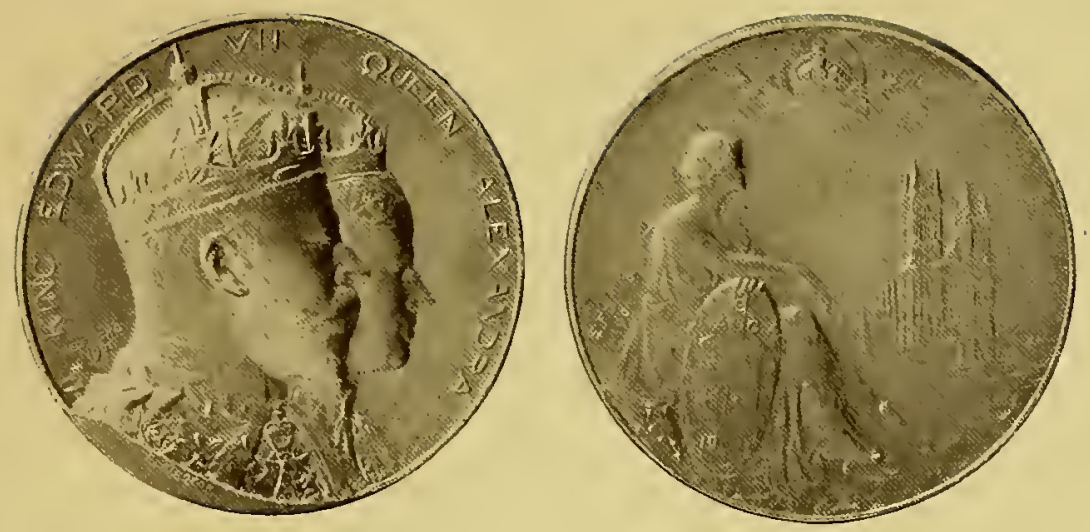

Official Coronaiton stedal

King Edward VII and Queen Hlexandra 


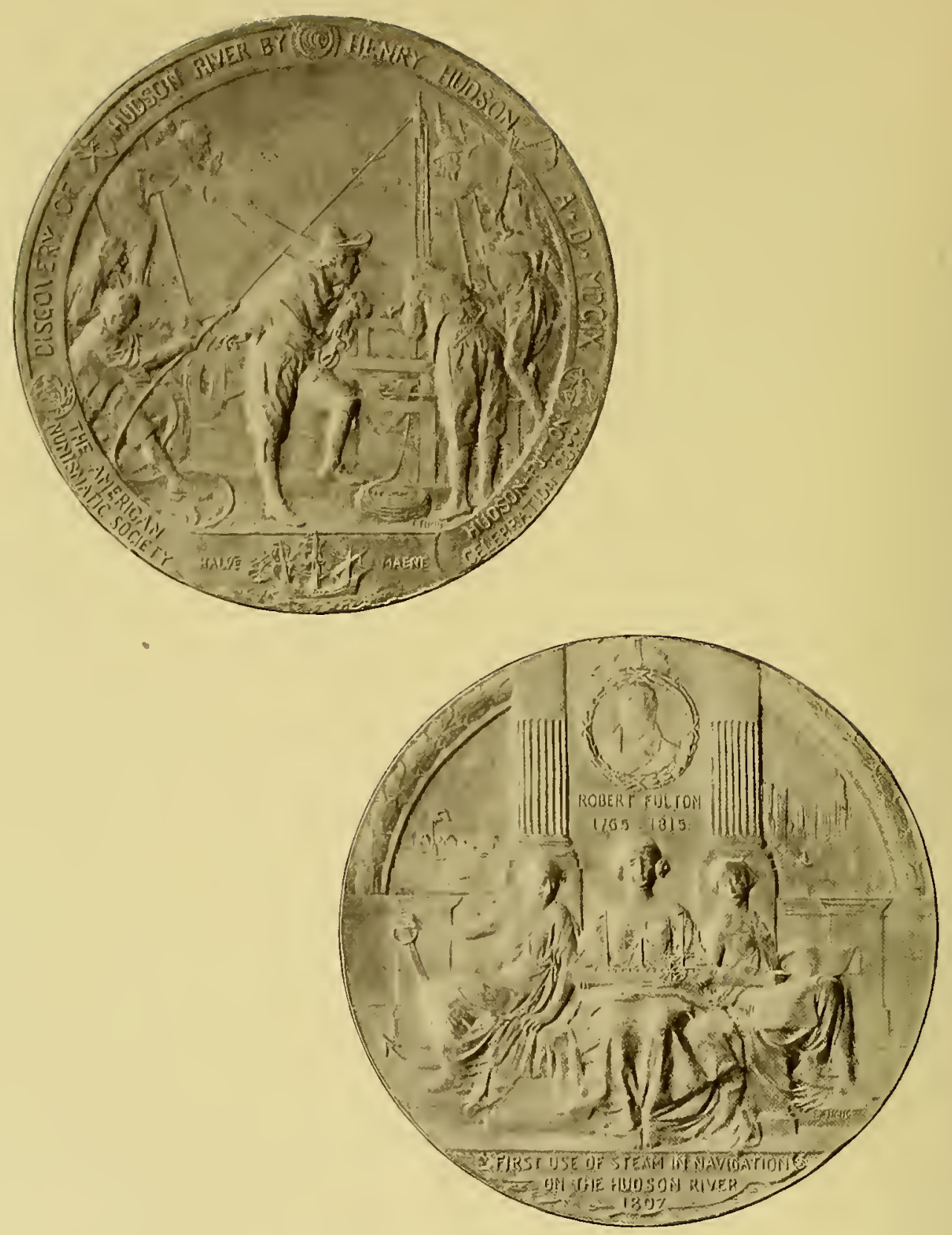

The Hudson-Fulton Commemoration Medal 

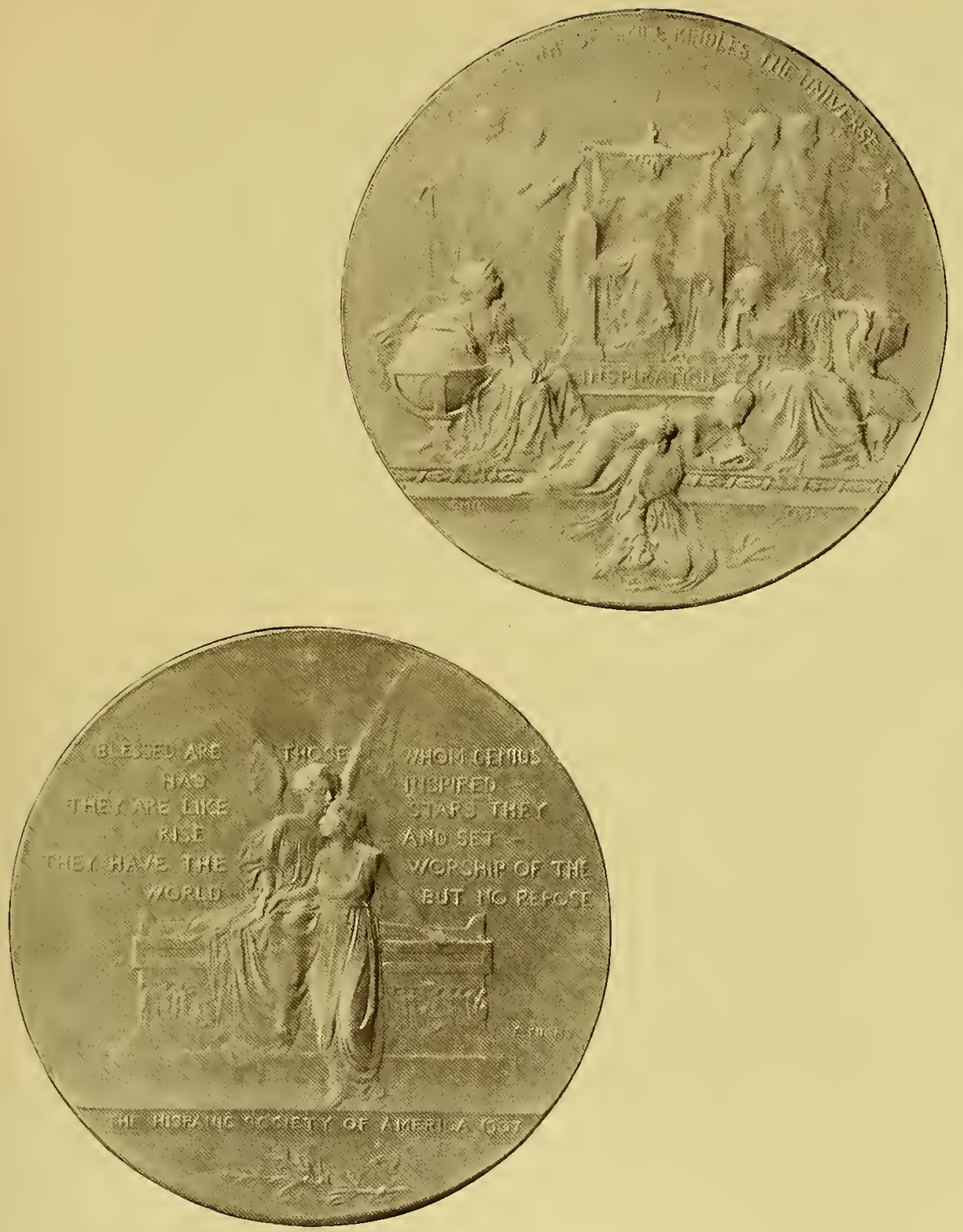

Medal for Disting Art and Music

DESIGNED FOR MR. ARCHER M. HUNTINGTON OF NEW YORK 

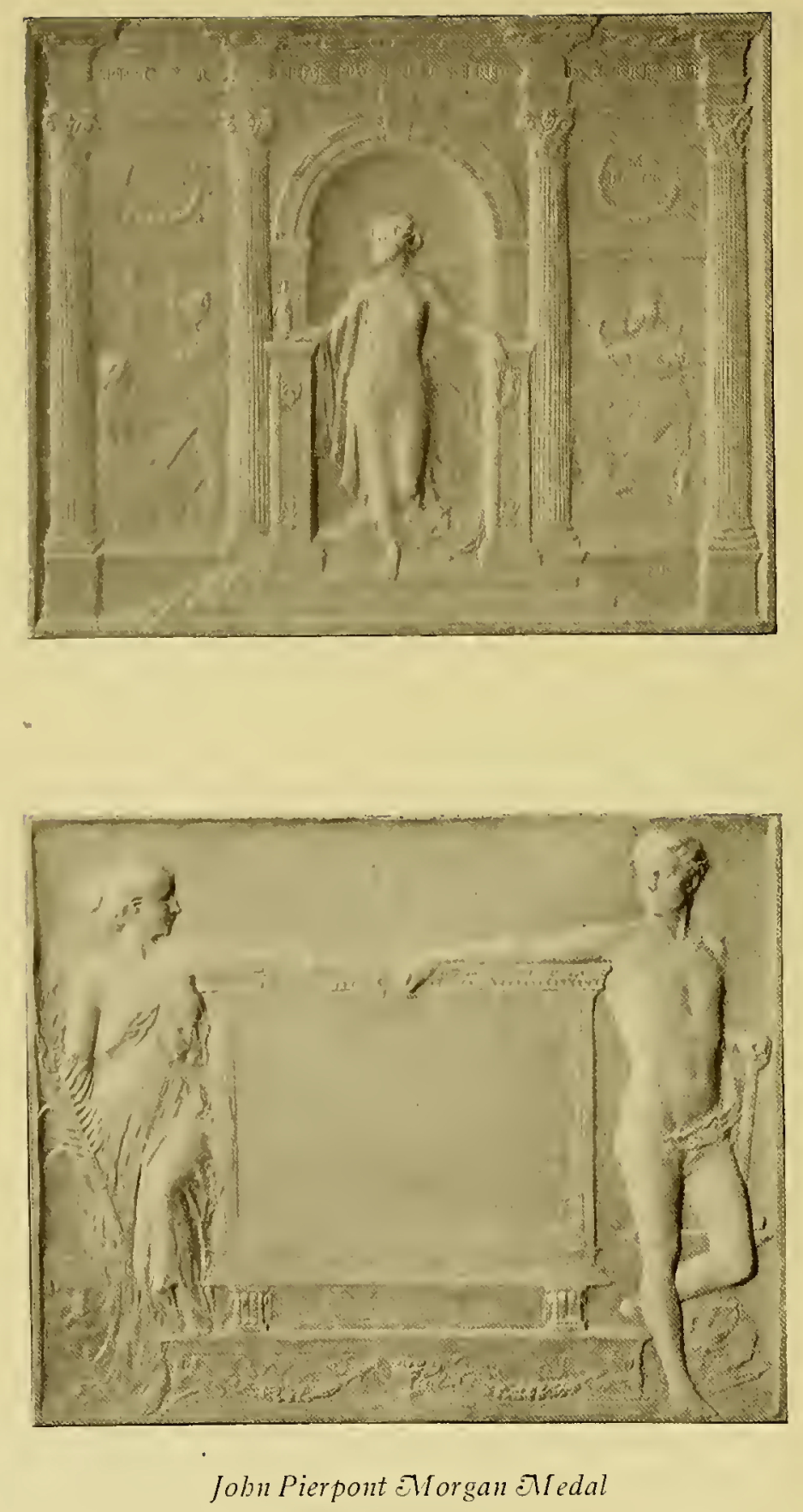

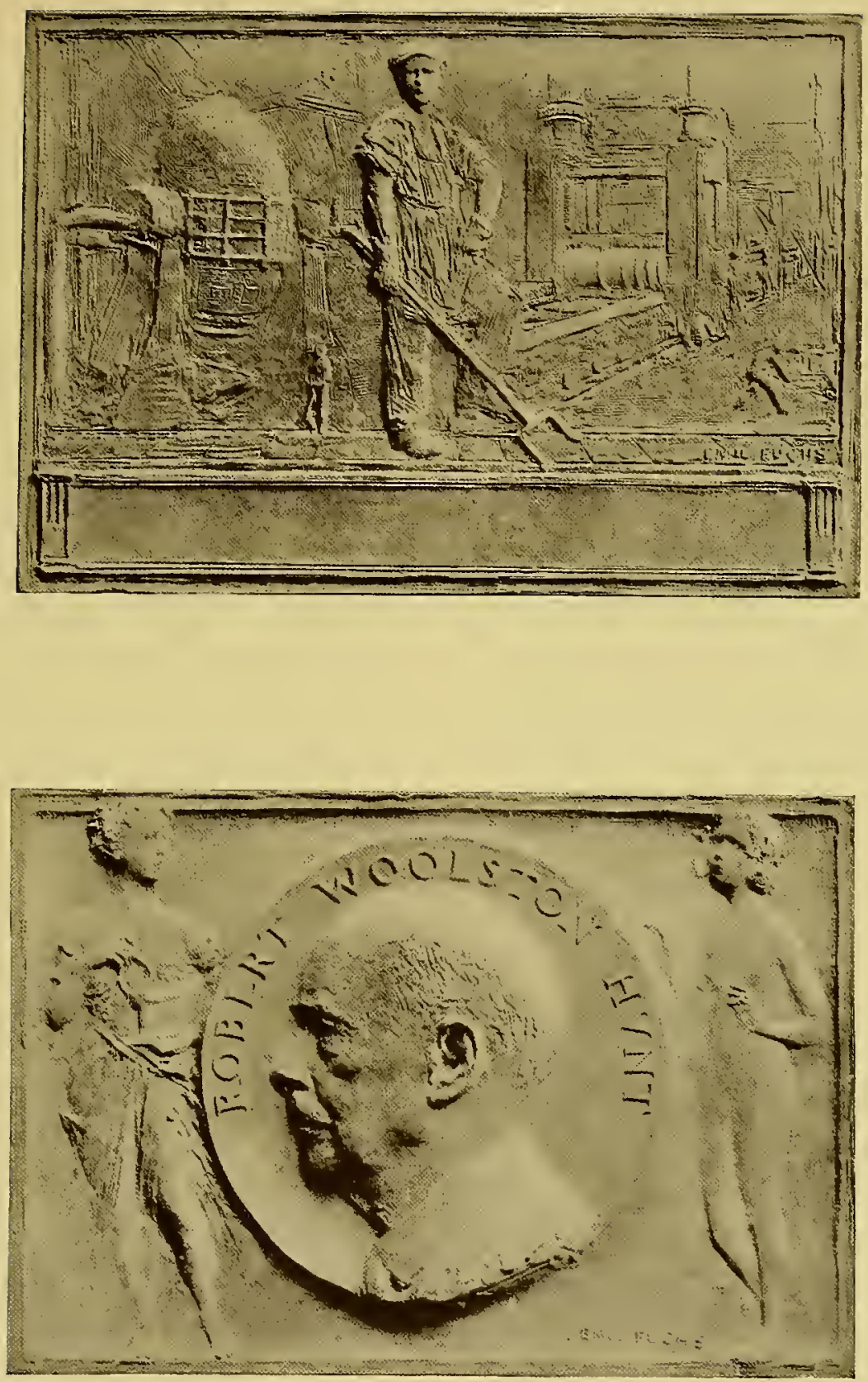

Robert W. Hunt Medal

DESIGNED FOR THE AMERICAN SOCIETY OF MINING AND METALLURGICAL ENGINEERS 

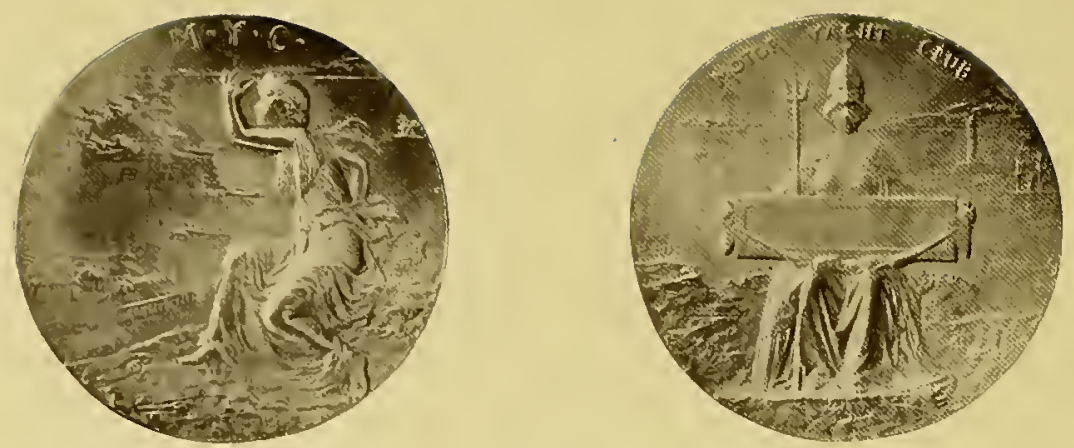

Medal-Motor Yacht Club of England
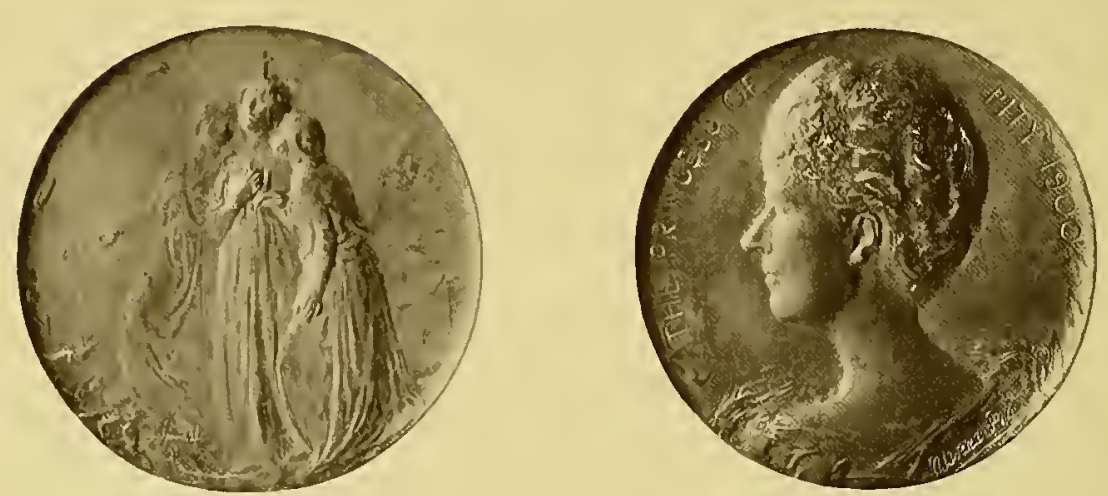

Queen eflexandra as Princess of Pity

Reverse (Faitb, Hope and Charity)
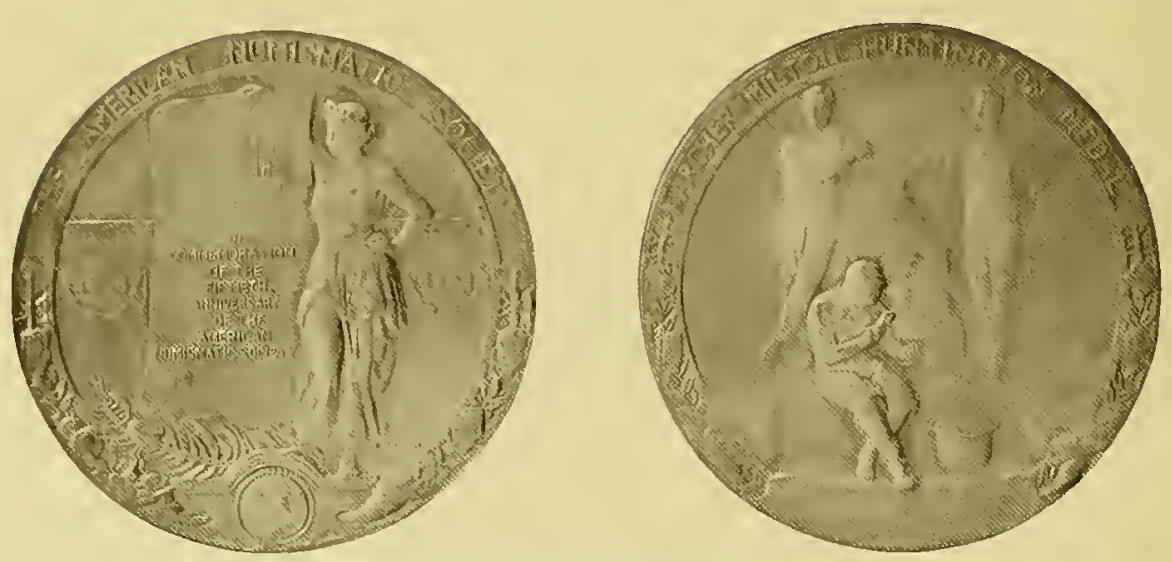

Membersbip Medal for

American Xumismatic Society 

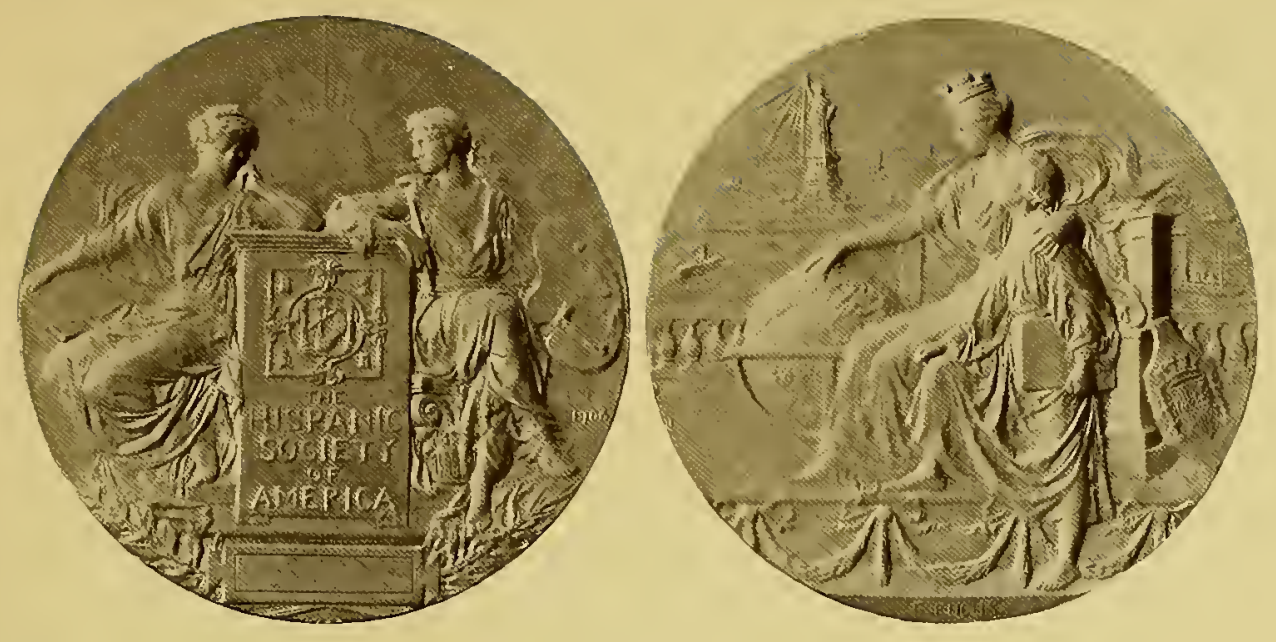

Membership Medal for the Hispanic Society of America
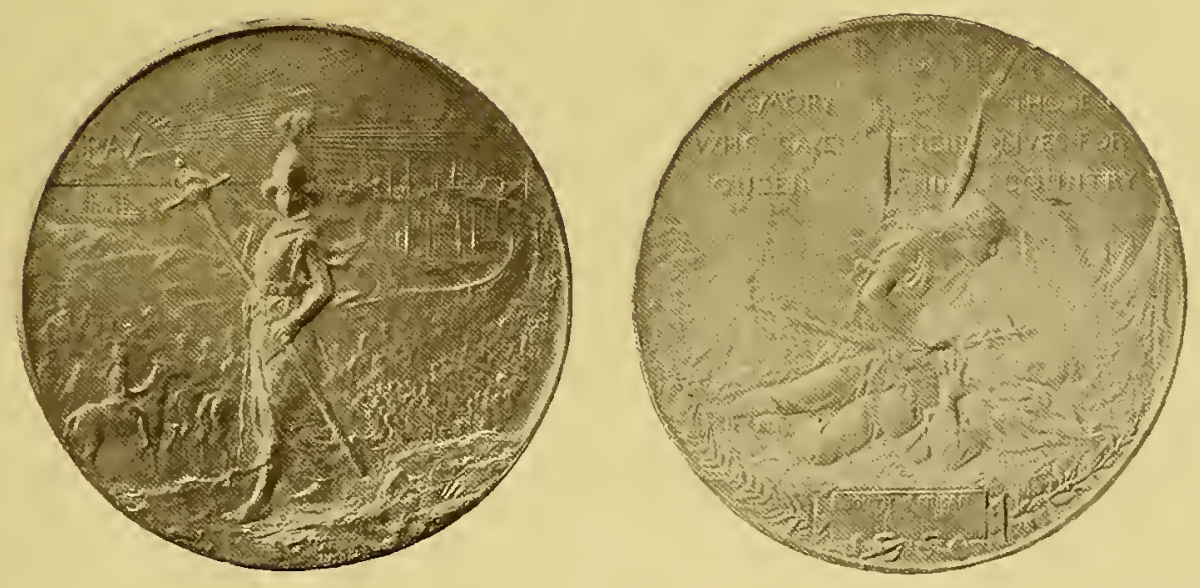

ETedal Commemorating

the Termination of the South effrican II ar 

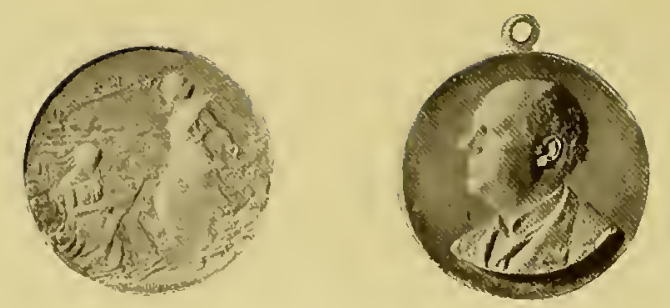

Lord Charles Beresford

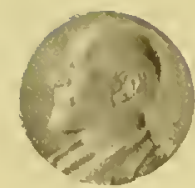

Sir Ernest Cassel

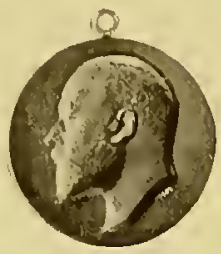

King Edward I'II

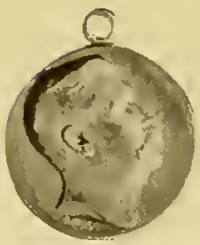

General Sir ctrthur Ellis EQUERRY TO KING EDWARD VII

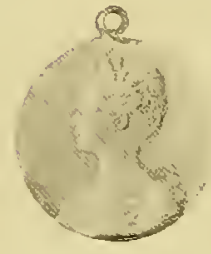

OTadame Ephrussi

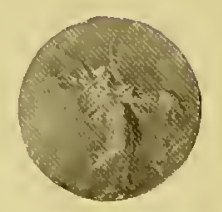

Lord Roberts N/edal REVERSE

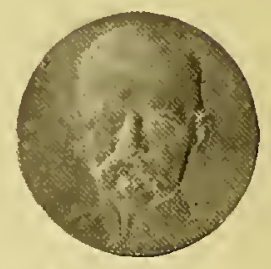

Field N R arsbal Lord Roberts
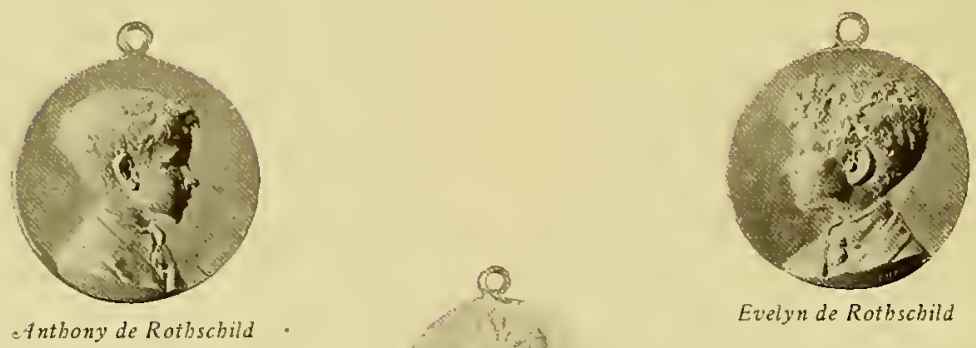

Evelyn de Rotbscbild 


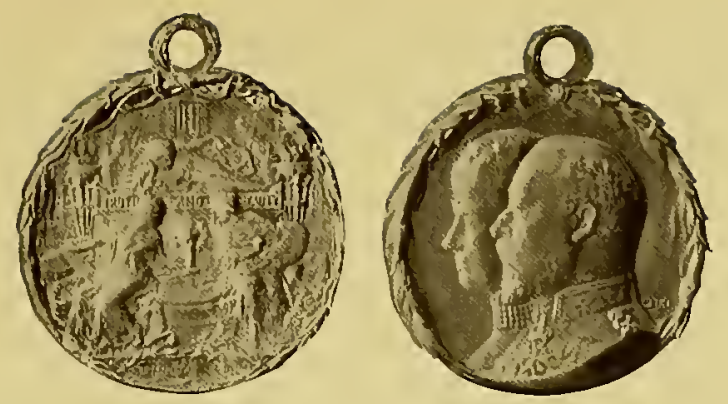

Medal Designed for King Edward VII

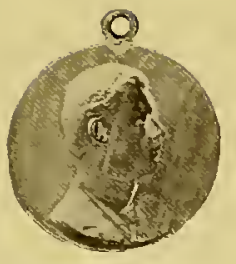

Jobn S. Cburcbill
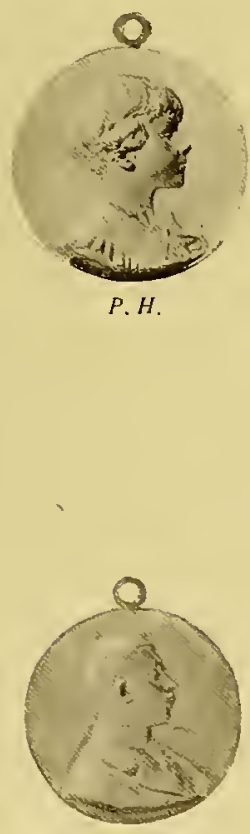

Count S.

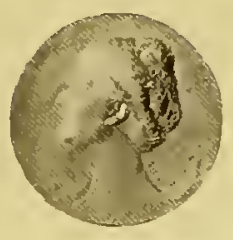

Princess Henry of Battenberg

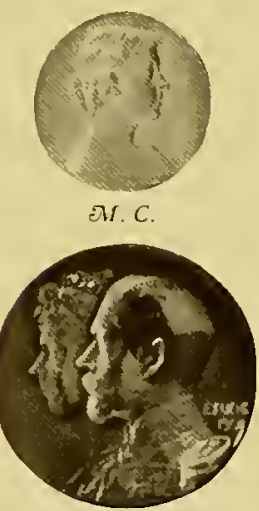

fing Geotge and Oueen or fary

COMLMEMORATING THEIR JOURNEY AROUND THE WORLO AS THE PRINCE AND PRINCESS OF WALES
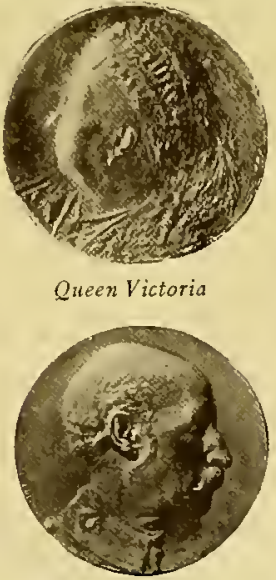

General Sir George Wbite DEFENDER OF LADYSMITH, SOUTH AFRICAN WAR

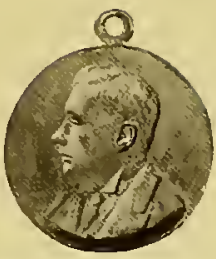

Winston S. Cburcbill SECRETARY FOR THE COLONIES
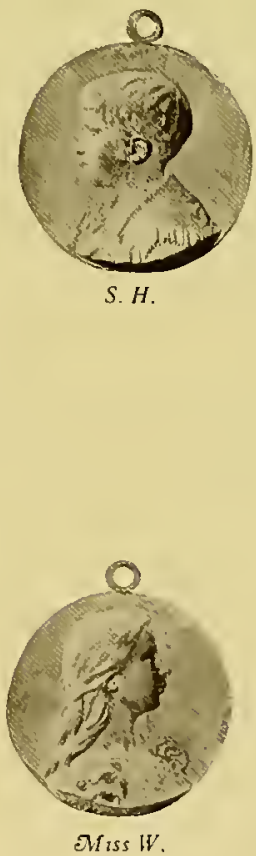

oriss $W$. 


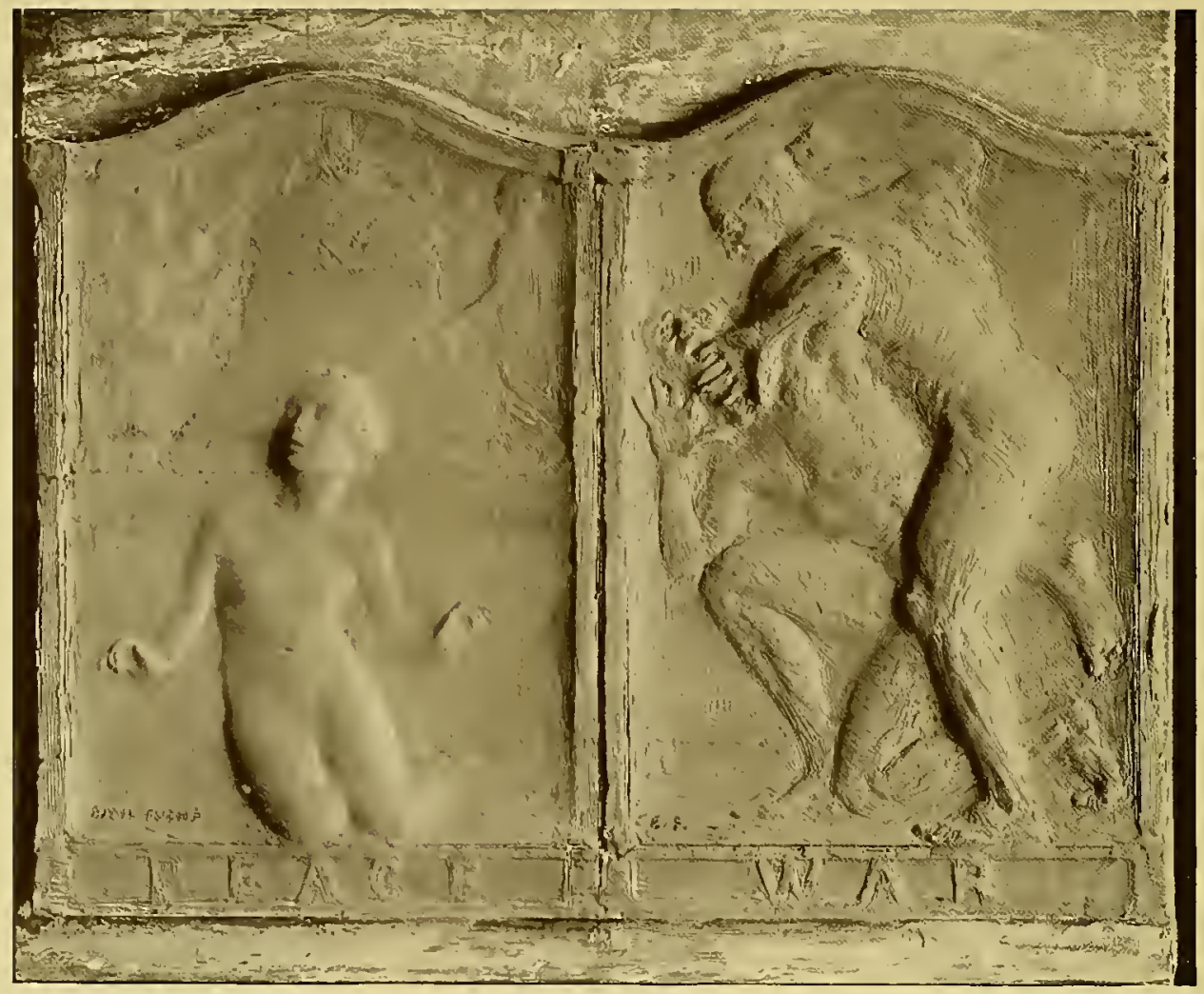

Mredal Commemorating the Signing of the Peace Treaty JUNe 28, 1919

DESIGNED FOR AND ISSUED BY MESSRS. CARTIER 
STUDIES 



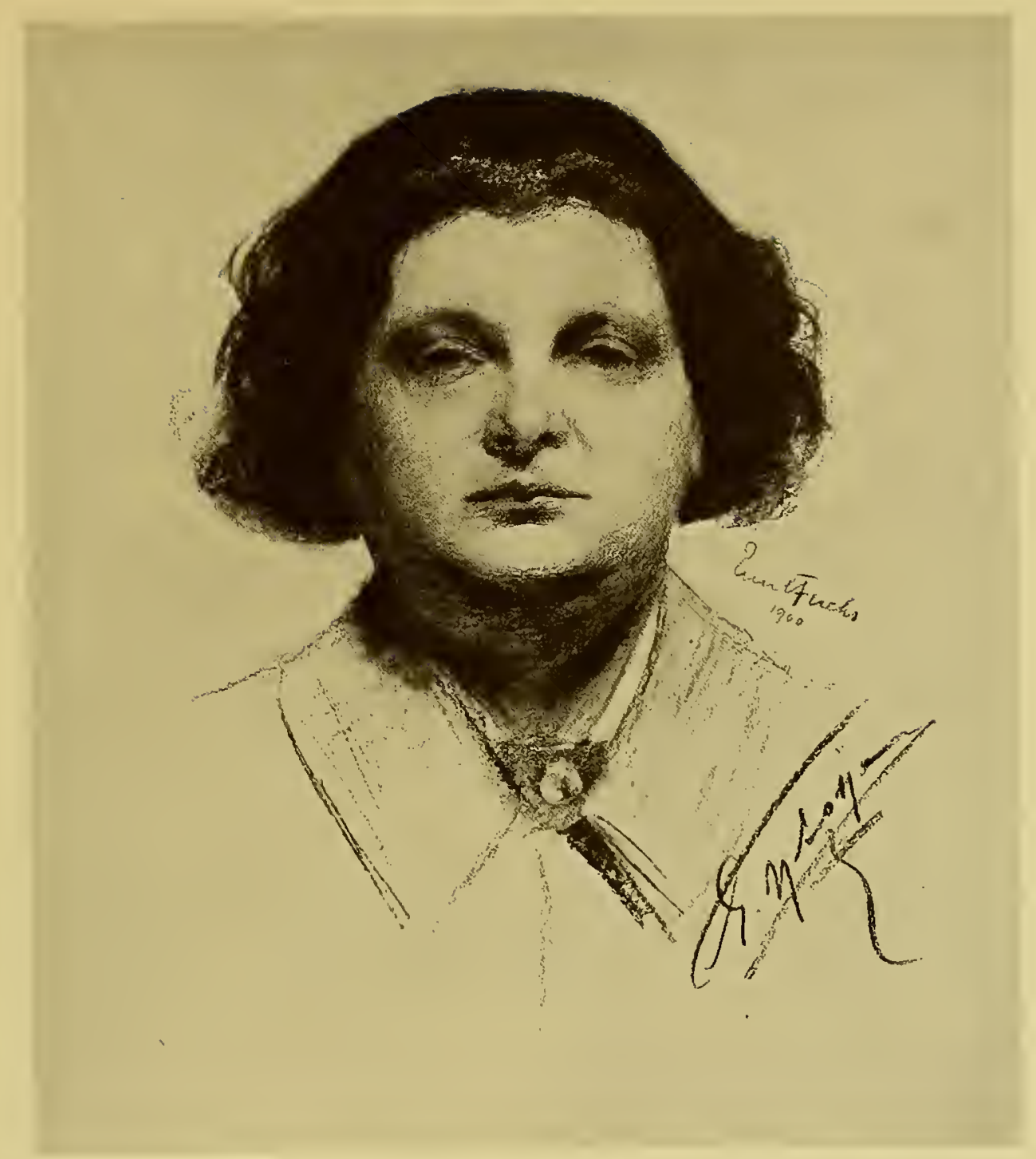

Ysaye 


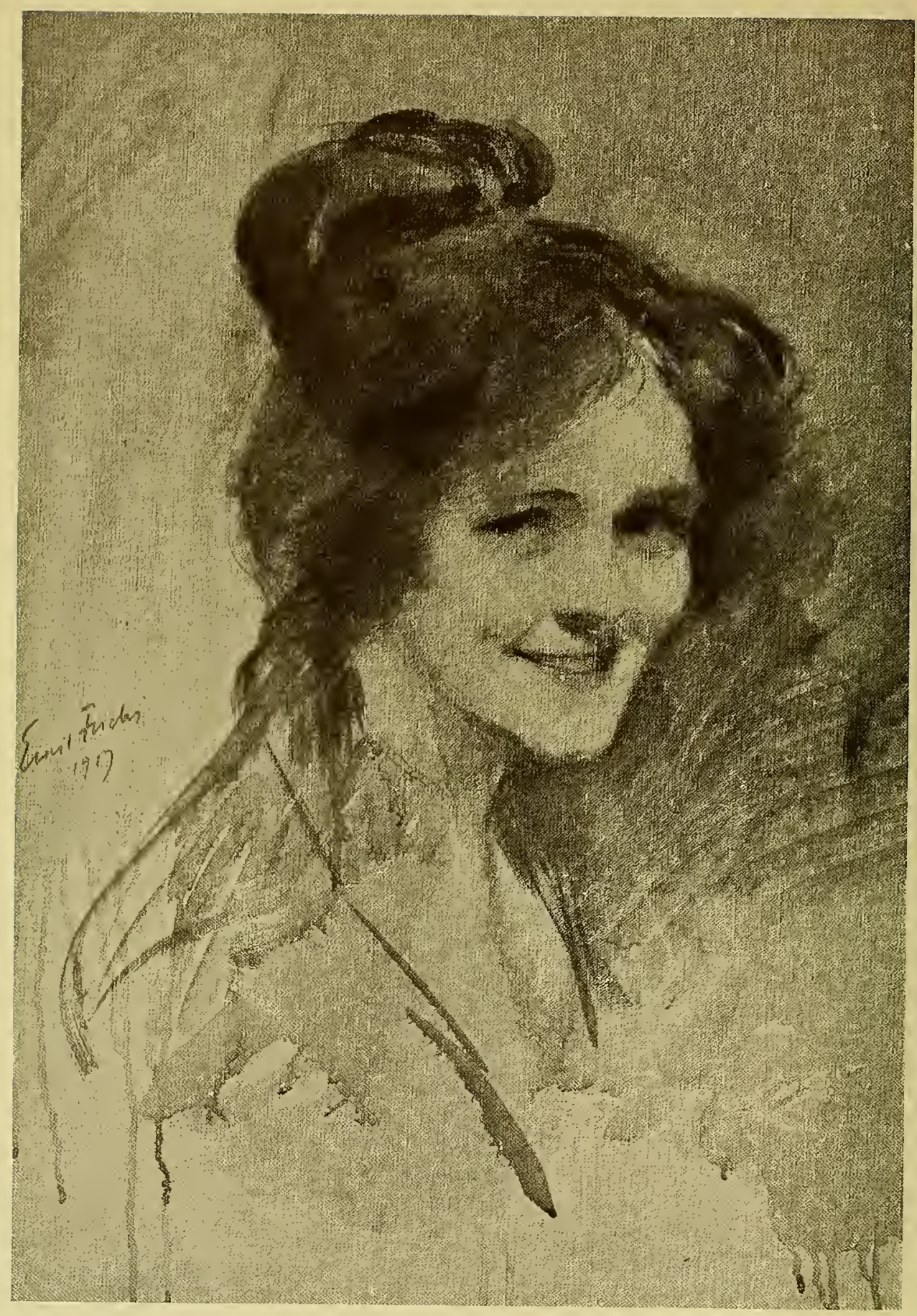

Beatrix 


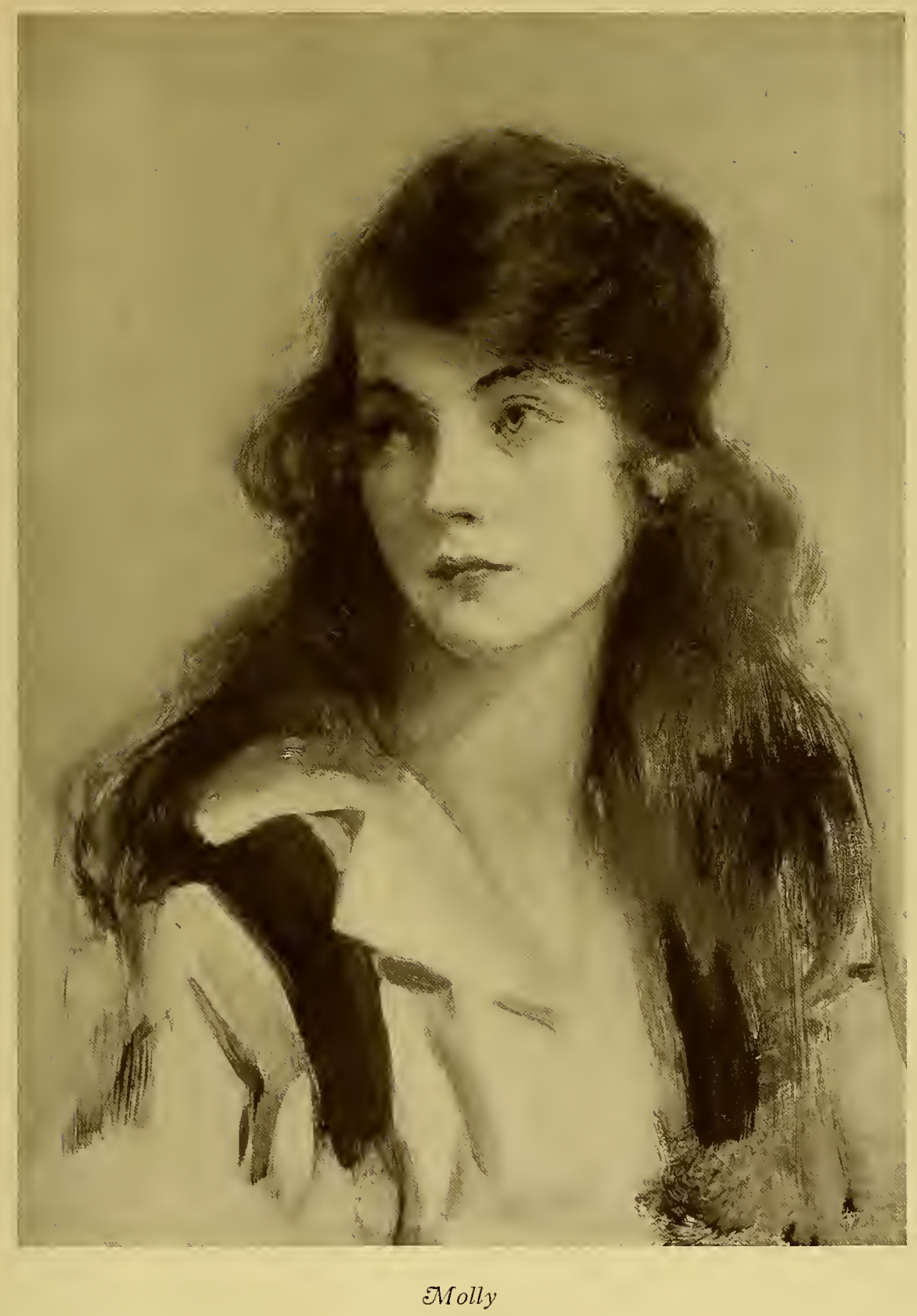




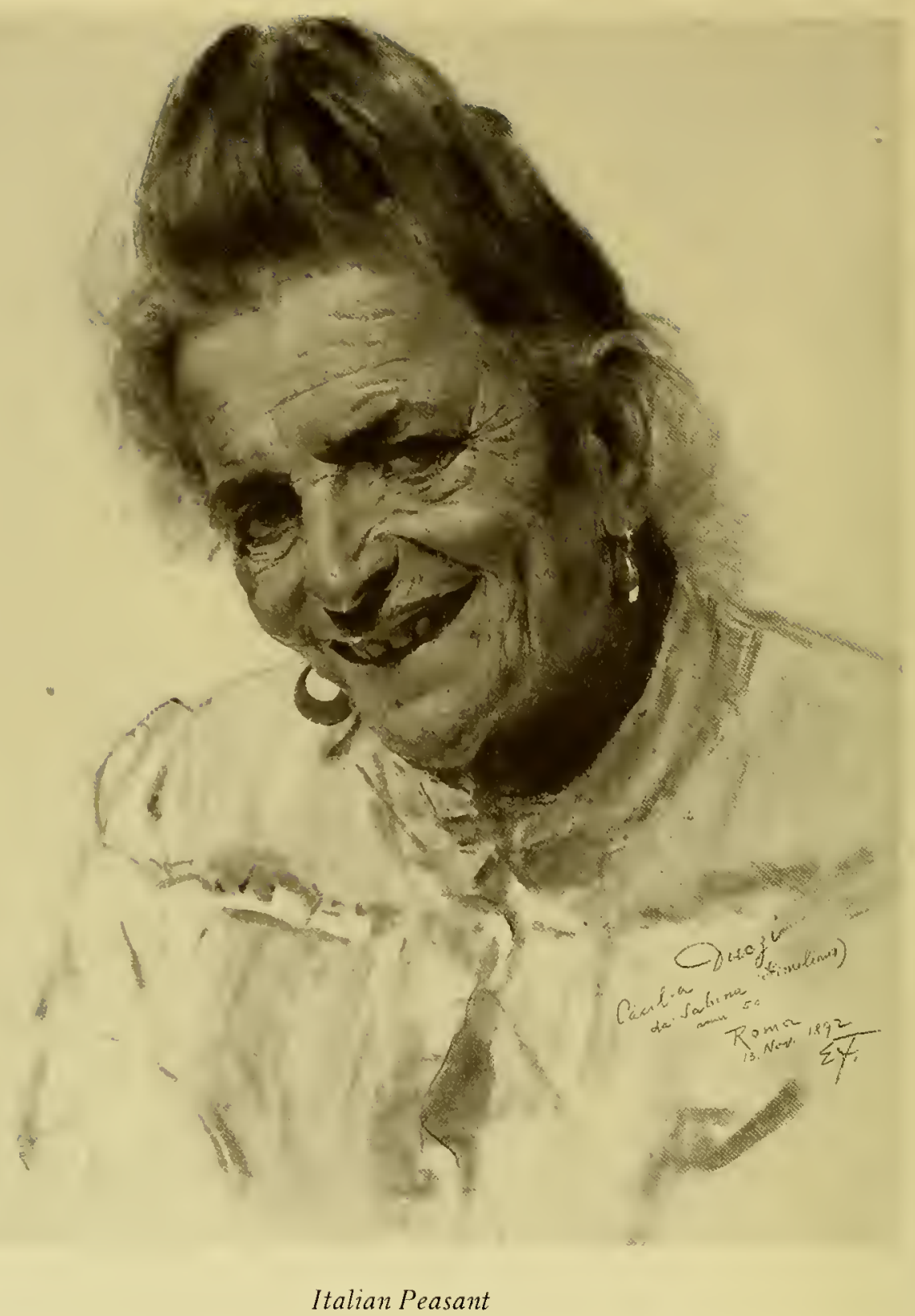

Italian Peasant 


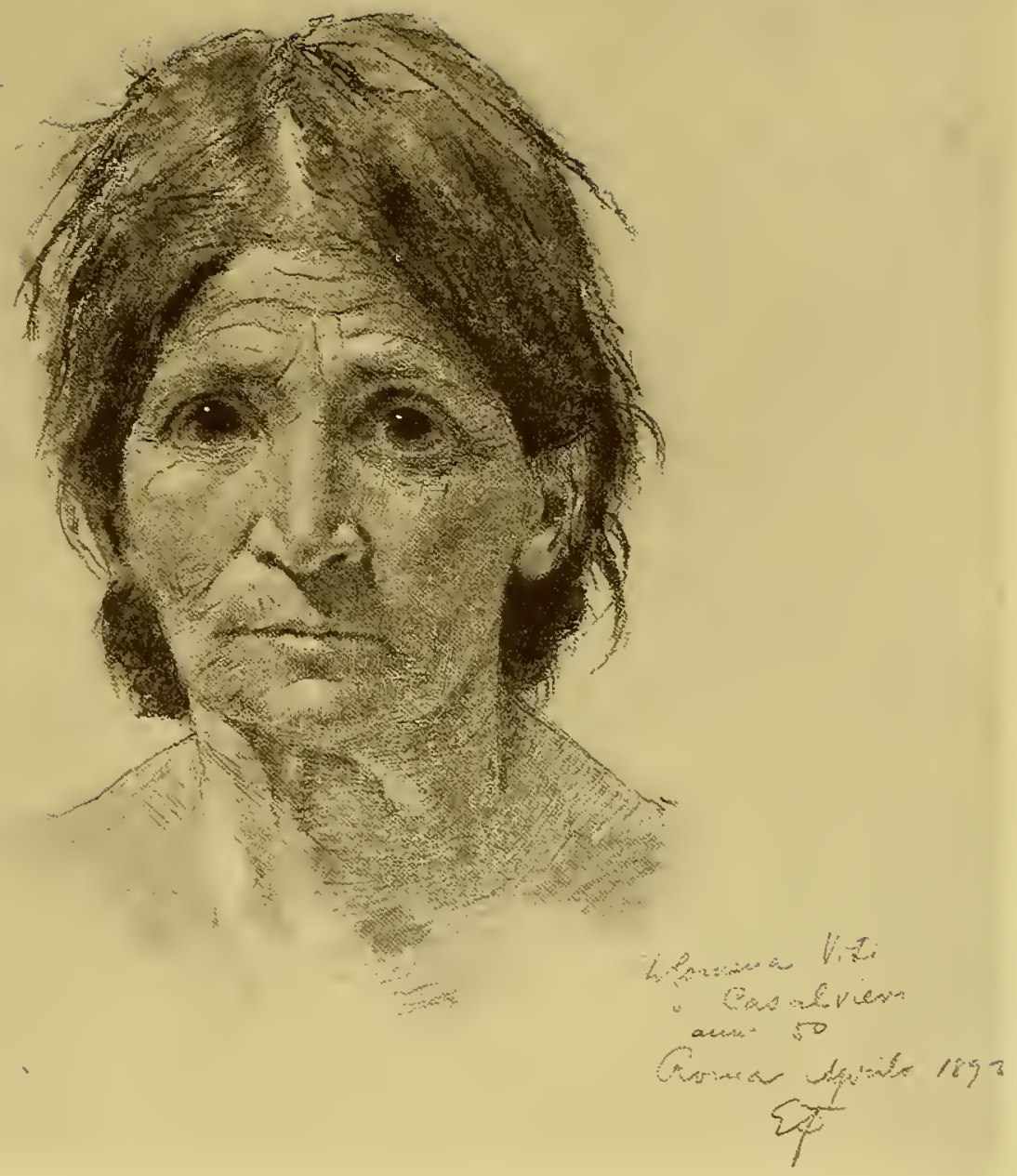




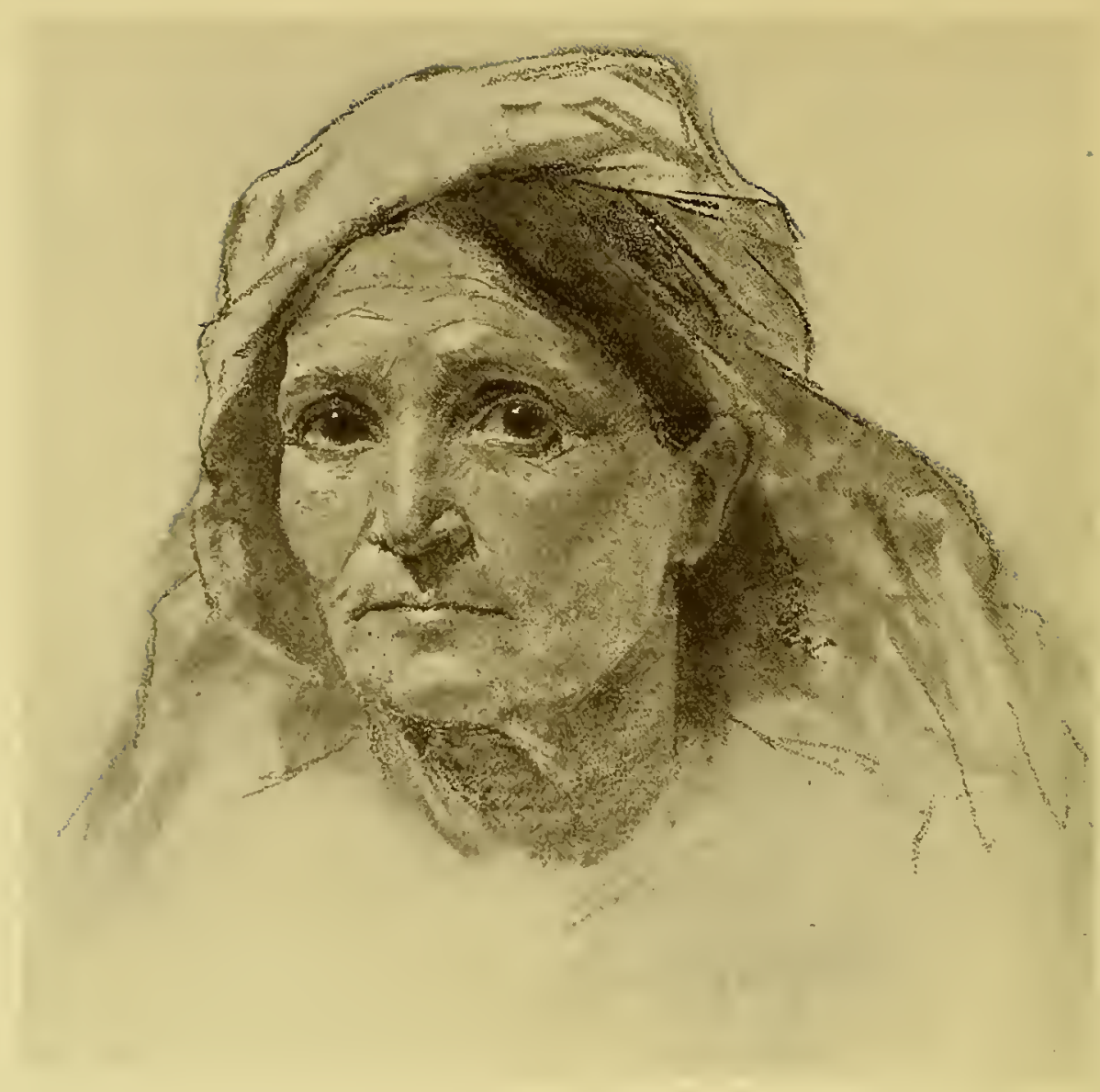




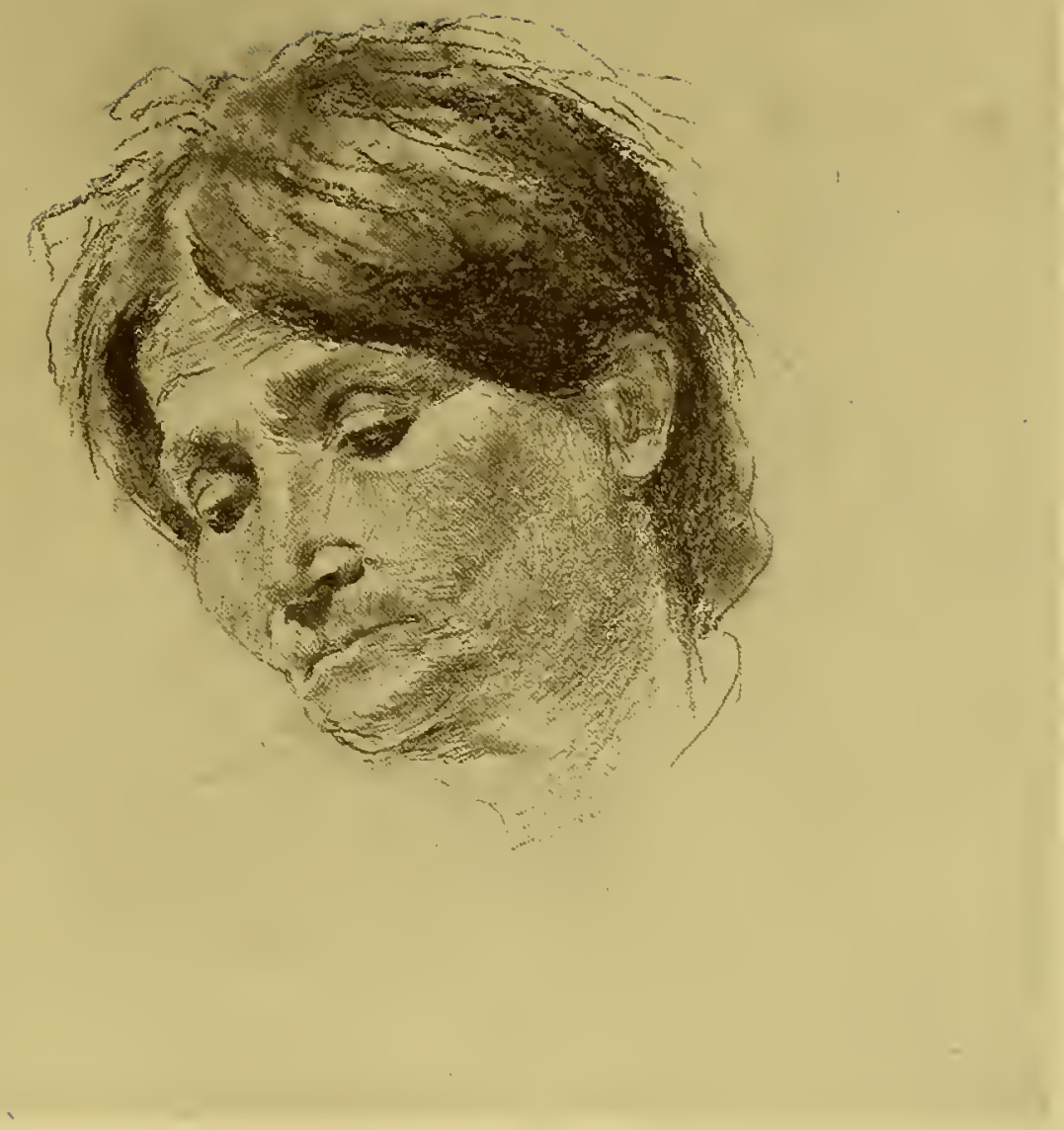




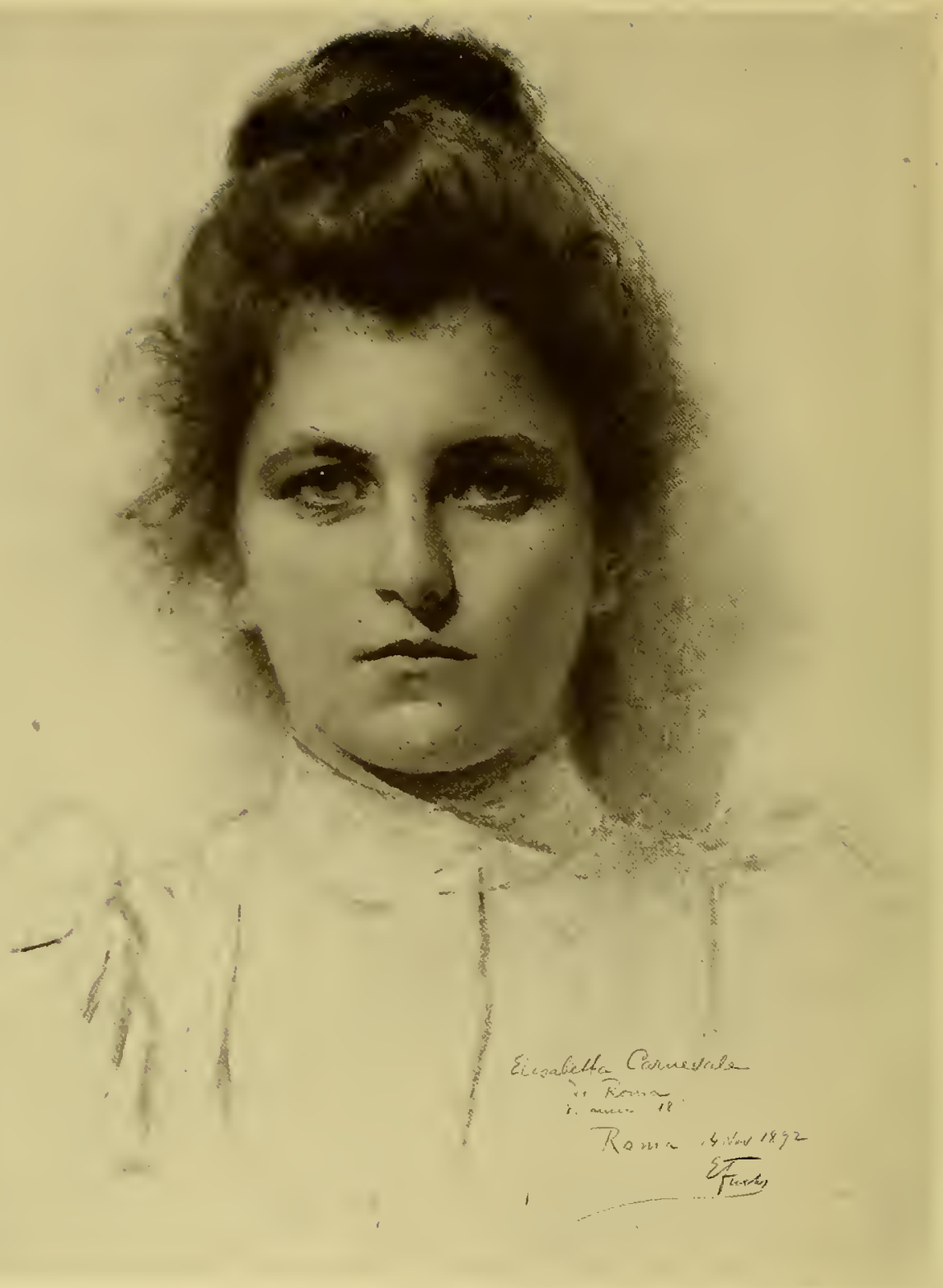

Italian News Vendor 


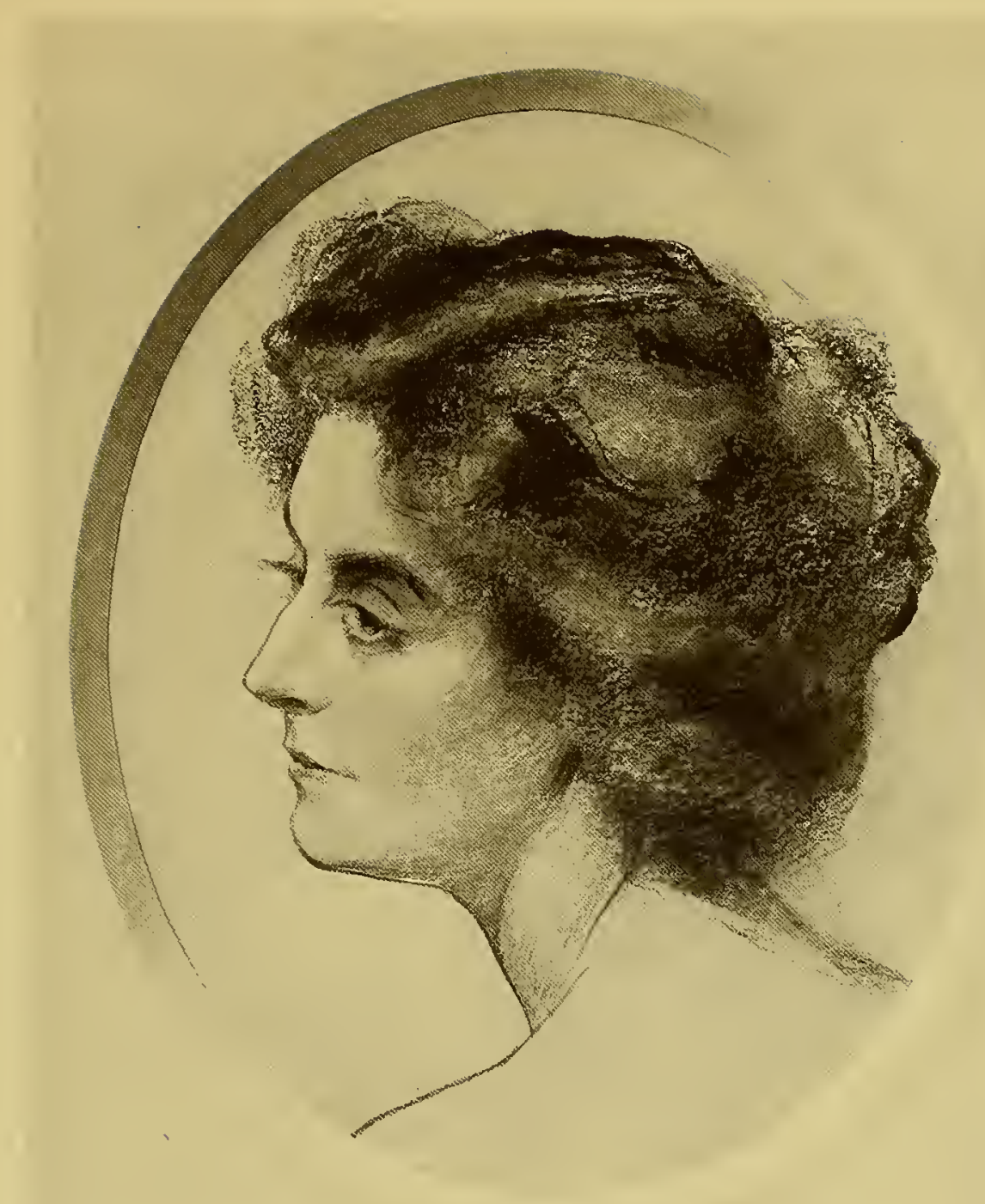

Baroness Aliotti 


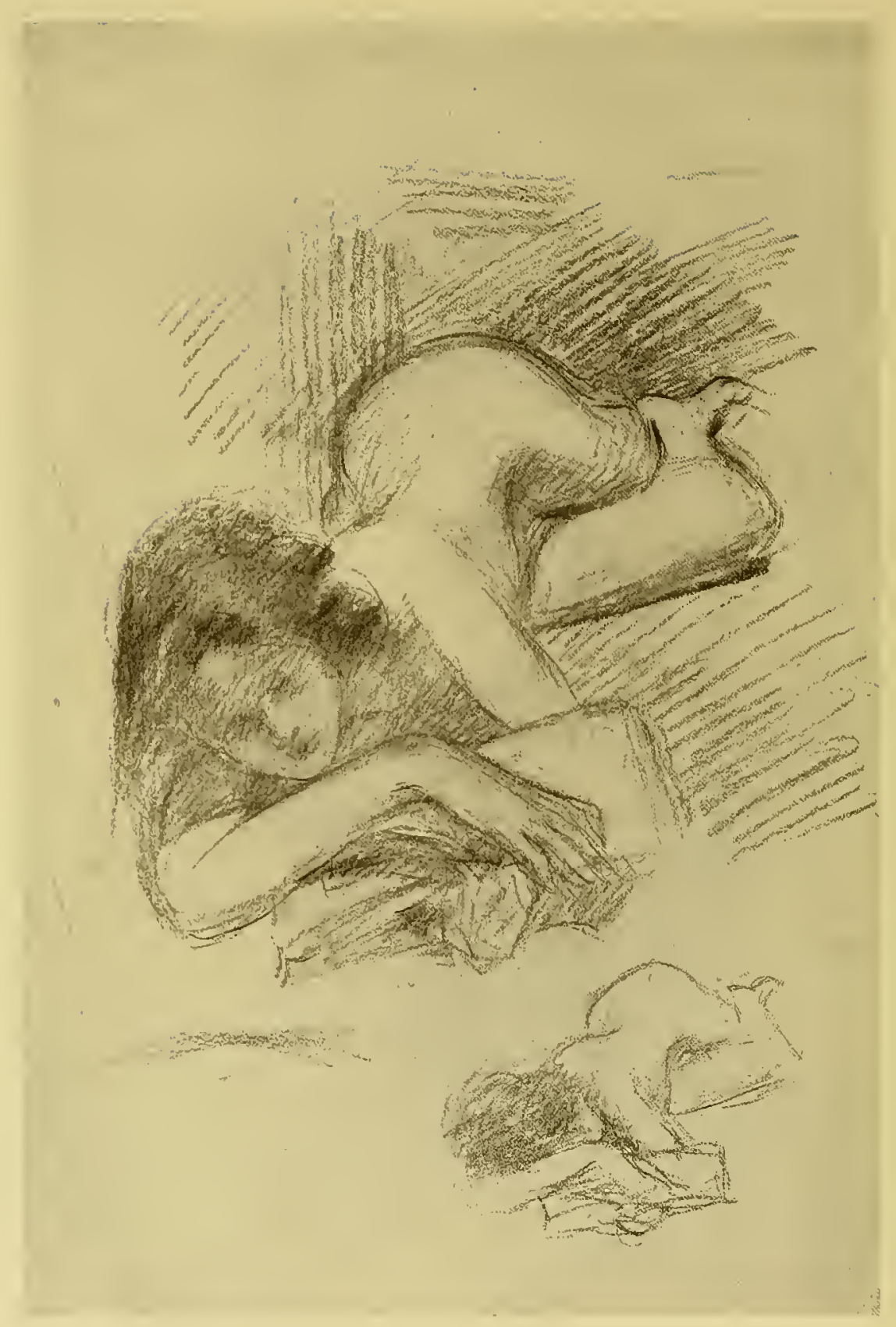



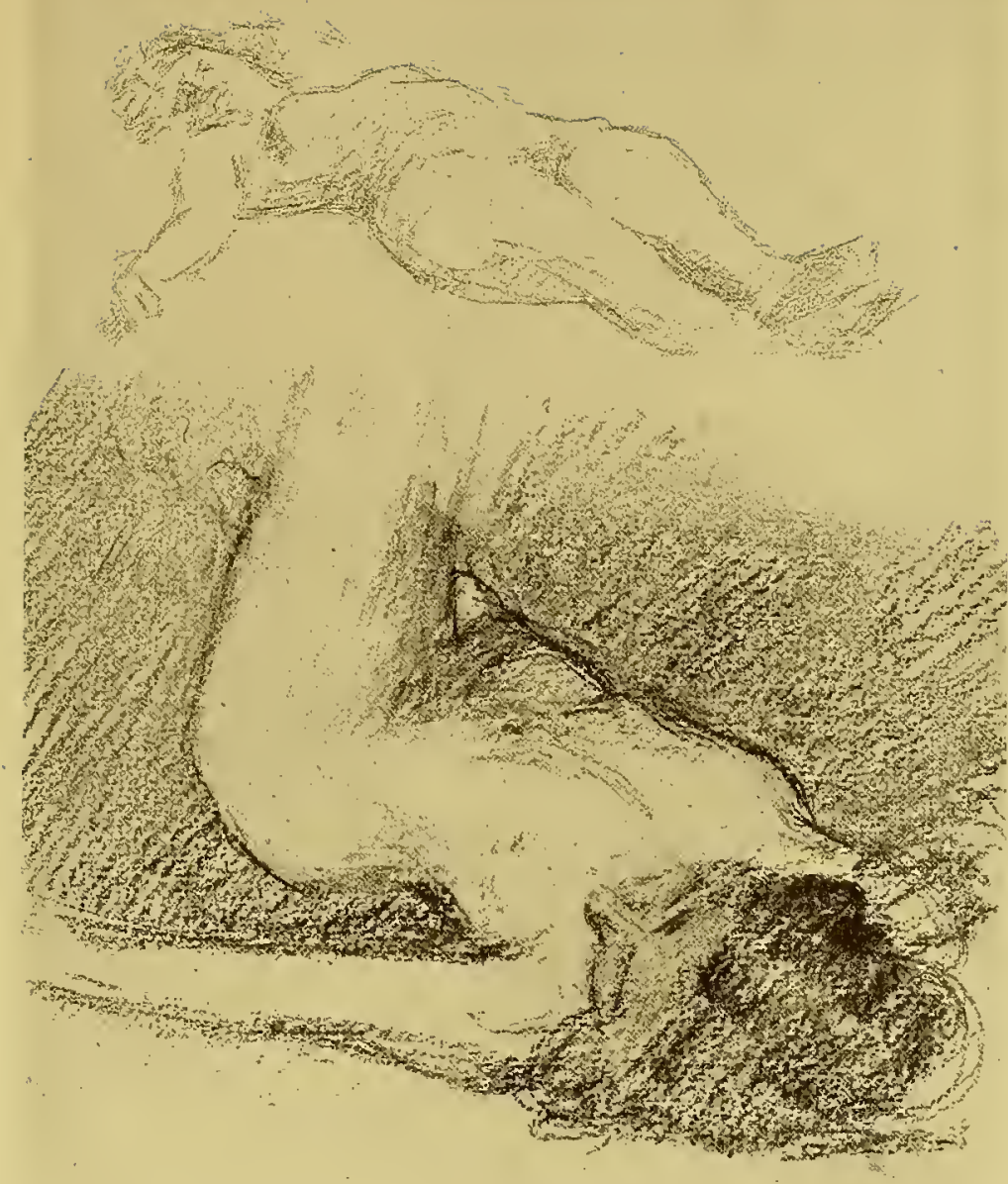

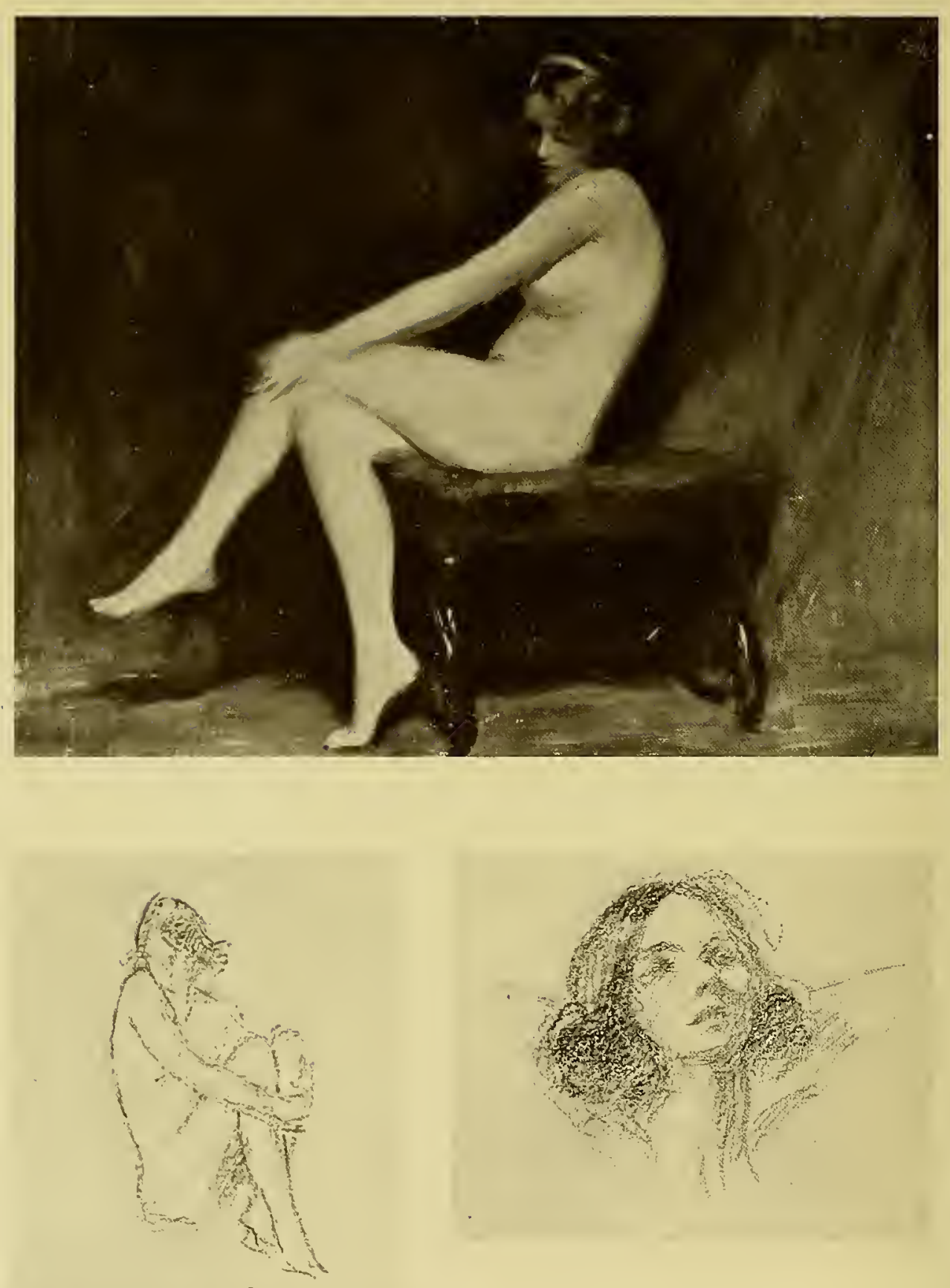


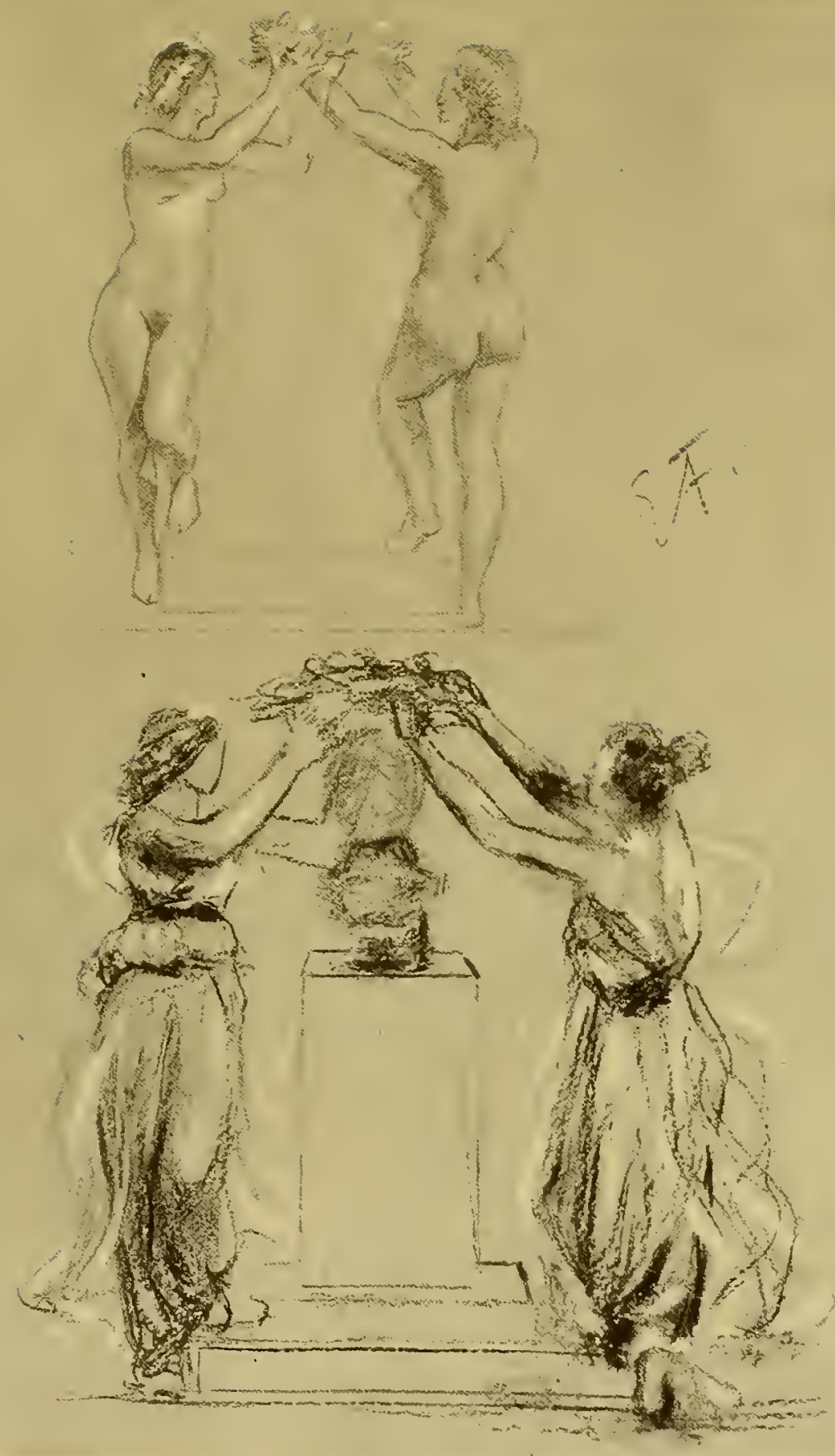



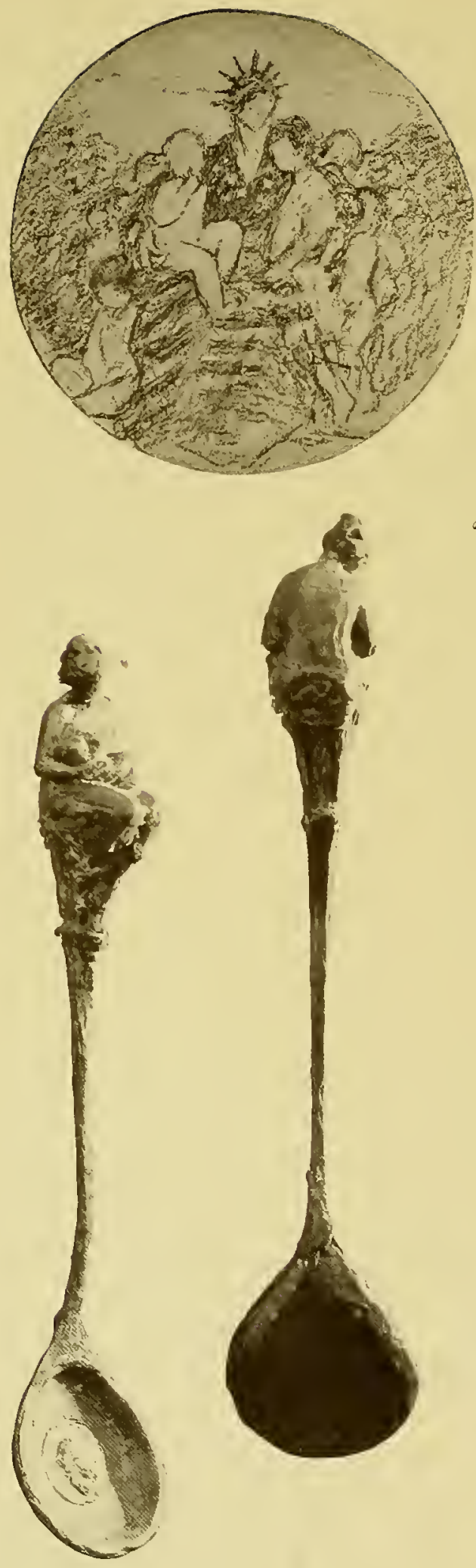

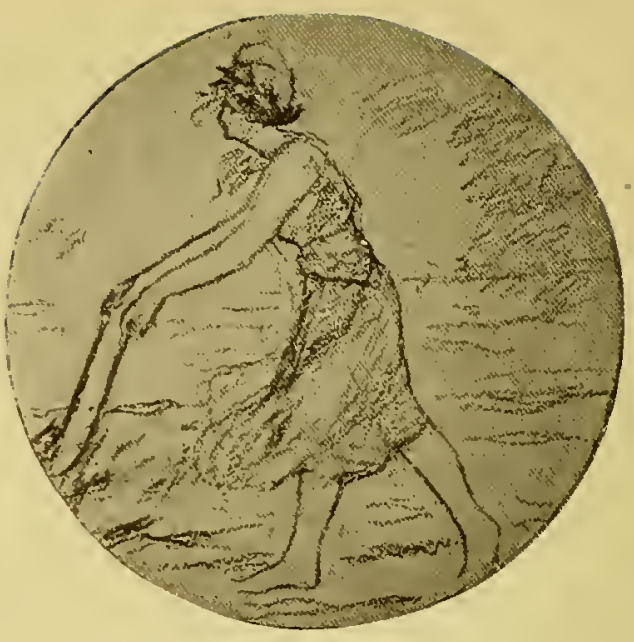

Design for Medal for the Committee for Derastated France
Birtbday Spoon

'Designed for Howard Heini, Esq. PITTSBURGH 


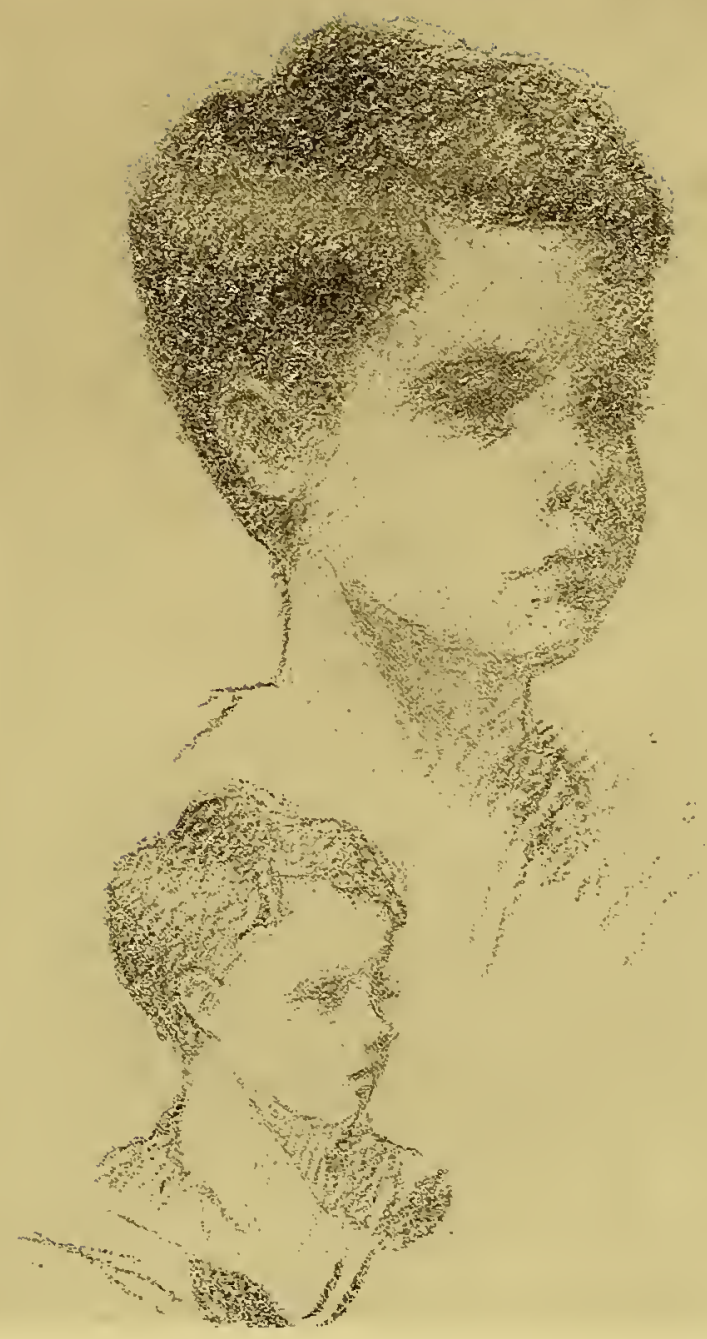



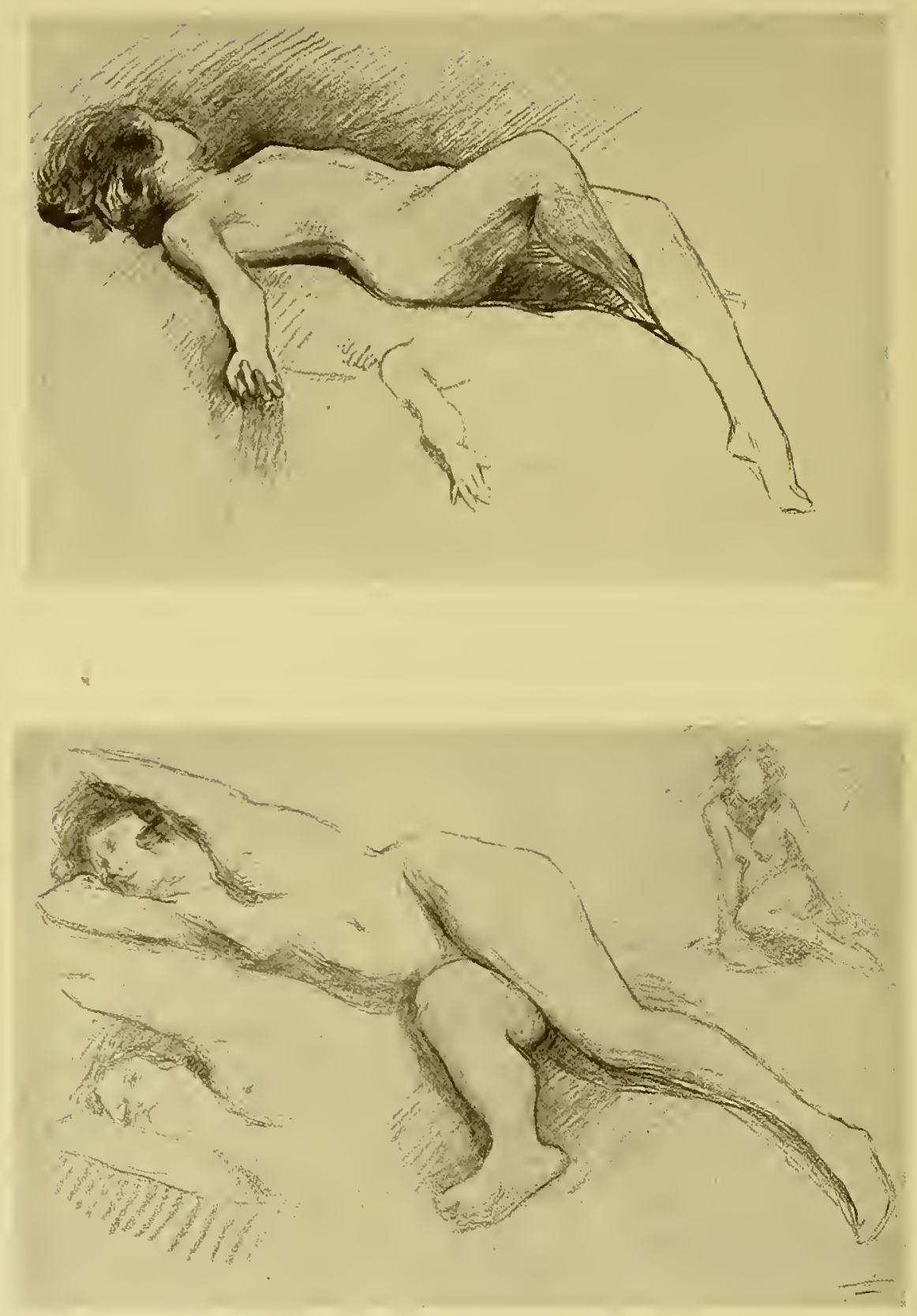

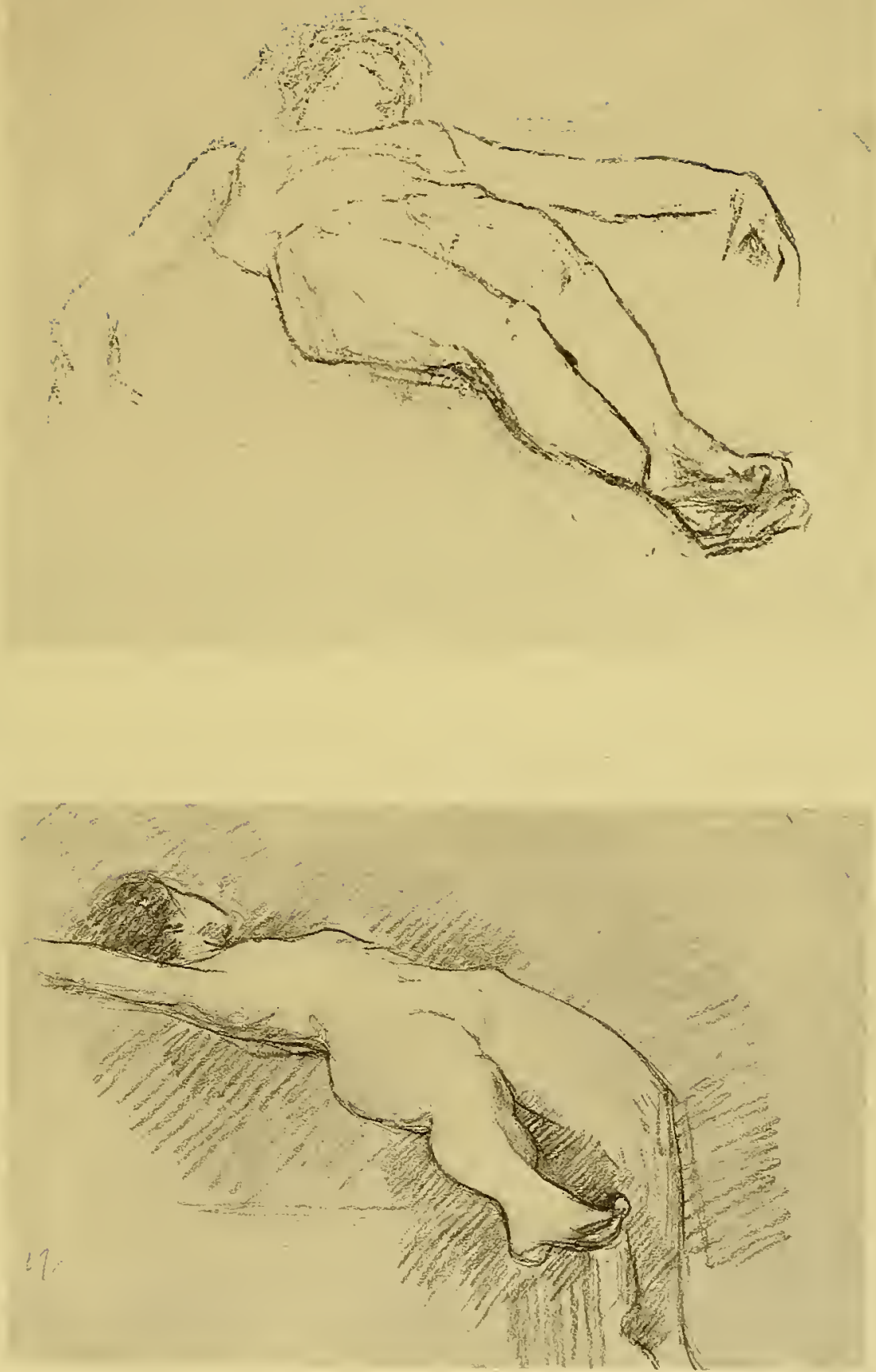


Most of the assembled Exhibits have never been shown before, except for the following:

$$
\begin{aligned}
& \text { The Bust of an Artist } \\
& \text { Maiden Meditation } \\
& \text { Lady Alice Montague } \\
& \text { Betty }
\end{aligned}
$$

which were shown at different years at the Royal Academy, London, also the National Academy of Design exhibited at various times:

Portrait Bust of a Lady
Alemories
Dawn
Reclining E Nude
Bust of an Artist.
Gari ETelchers
Forbes-Robertson
The Peace ENedal

The Peace Medal and the Bust of a Lady were exhibited by special invitation at the Albright Galleries in Buffalo, and EMemories at the Pennsylvania Academy of Fine Arts.

All of the works are Originals with the exception of Lady Alice ANontague which is a replica of the bust in the Royal collection in England.

Of La Pensierosa at The Metropolitan Museum of Art (also an Original), the proof-cast is in the collection of Lord Harcourt, London.

The issue of Butterfly is limited to twenty copies, of which seven are unissued, and Eva, Study of a E 'ude to six copies, three unissued.

A record is kept of the names of the owners of these copies, so as to prevent indiscriminate reproduction, which can only be injurious to the quality of the work. 


10 


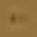

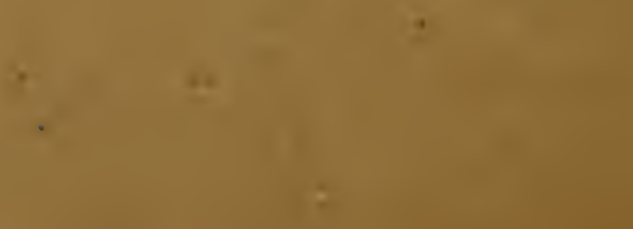



SMITHSONIAN INS IITUTION LIBRARIES

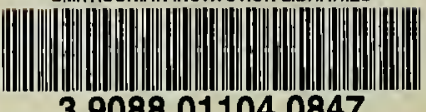

39088011040847 